\title{
Interventions for non-metastatic squamous cell carcinoma of the skin: systematic review and pooled analysis of observational studies
}

\author{
Louise Lansbury research associate ${ }^{1}$, Fiona Bath-Hextall reader in evidence based healthcare ${ }^{12}$, \\ William Perkins consultant dermatologist ${ }^{3}$, Wendy Stanton librarian ${ }^{4}$, Jo Leonardi-Bee associate \\ professor in medical statistics ${ }^{5}$
}

${ }^{1}$ Centre of Evidence Based Dermatology, University of Nottingham, Nottingham NG7 2NR, UK; ${ }^{2}$ School of Health Sciences, University of Nottingham, Nottingham, UK; ${ }^{3}$ Department of Dermatology, Nottingham University Hospitals NHS Trust, Queen's Medical Centre, Nottingham, UK; ${ }^{4}$ Greenfield Medical Library, Nottingham Education Centre, University of Nottingham, UK; ${ }^{5}$ Division of Epidemiology and Public Health, University of Nottingham, Nottingham City Hospital, Nottingham, UK

\begin{abstract}
Objectives To assess the effects of treatments for non-metastatic invasive squamous cell carcinoma (SCC) of the skin using evidence from observational studies, given the paucity of evidence from randomised controlled trials.

Design Systematic review of observational studies.

Data sources Medline, Embase, to December 2012.

Review methods Observational studies of interventions for primary, non-metastatic, invasive, SCC of the skin that reported recurrence during follow-up, quality of life, initial response to treatment, adverse events, cosmetic appearance, or death from disease. Studies were excluded if data for primary cutaneous SCC was not separable from other data. Data were extracted independently by two reviewers. Meta-analysis was performed where appropriate using a random effects model to estimate the pooled proportion of an event with $95 \%$ confidence intervals.

Results 118 publications were included, covering seven treatment modalities. Pooled estimates of recurrence of SCCs were lowest after cryotherapy (0.8\% (95\% confidence interval $0.1 \%$ to $2 \%)$ ) and curettage and electrodesiccation ( $1.7 \%(0.5 \%$ to $3.4 \%))$, but most treated SCCs were small, low risk lesions. After Mohs micrographic surgery, the pooled estimate of local recurrence during variable follow-up periods from 10 studies was $3.0 \%$ (2.2\% to $3.9 \%$ ), which was non-significantly lower than the pooled average local recurrence of $5.4 \%(2.5 \%$ to $9.1 \%)$ after standard surgical excision (12 studies), and 6.4\% (3.0\% to $11.0 \%$ ) after external radiotherapy ( 7 studies). After an apparently successful initial
\end{abstract}

response of SCCs to photodynamic therapy, pooled average recurrence of $26.4 \%$ ( $12.3 \%$ to $43.7 \%$; 8 studies) was significantly higher than other treatments. Evidence was limited for laser treatment (1 study) and for topical and systemic treatments (mostly single case reports or small non-comparative series with limited follow-up).

Conclusions Many observational studies have looked at different treatment modalities for SCC, but the evidence base for the effectiveness of these interventions is poor. Comparison of outcomes after different treatments should be interpreted cautiously owing to biases inherent in the types of study included, and lack of direct comparisons to enable the estimation of relative treatment effect. Further evidence is needed to develop a prognostic model and stratify individuals at high risk of developing SCC, to improve the evidence base for this common cancer and to optimise clinical management.

Protocol registration International Prospective Register of Systematic Reviews (PROSPERO) registration number CRD42011001450.

\section{Introduction}

Cutaneous squamous cell carcinoma (SCC), the second most common type of non-melanoma skin cancer after basal cell carcinoma, arises most commonly in sun exposed areas of the body from keratinocytes in the epidermis. Invasive SCC, characterised histologically by the spread of malignant cells into the dermis, could arise de novo or from the transformation of precursor lesions such as actinic keratosis and Bowen's disease. The tumour could present clinically as a smooth or 
hyperkeratotic enlarging plaque, nodule, or ulcer and could be associated with pain, pruritus, or bleeding when traumatised. Induration, the limits of which might not be sharply defined, can spread beyond the extent of a clinically apparent tumour. Invasive SCC can recur and metastasise to regional lymph nodes or distant organs and, if left untreated or inadequately treated, can cause extensive local tissue destruction.

Worldwide, the incidence of SCC has been increasing since the 1960s. ${ }^{1}$ More than $80 \%$ of non-melanoma skin cancers occur in people aged 60 years and older, and with an increasingly ageing population, the workload of non-melanoma skin cancers for dermatologists in the United Kingdom has been predicted to increase by $50 \%$ by $2030 .^{2}$ Additionally, solid organ transplant recipients are at particular risk of developing SCC. ${ }^{3-5}$ In one cohort study of more than 1000 ethnically diverse, solid organ transplant recipients followed prospectively over a 22 year period, this group showed a 153 -fold excess risk for developing SCC and dying from it compared with the general population. ${ }^{6}$

The aims of treatment of SCC are to completely remove or destroy the tumour and to minimise functional and cosmetic impairment. Stratification of patients based on the American Joint Committee on Cancer's staging system, which takes into account tumour features associated with a worse prognosis (tumour diameter $>2 \mathrm{~cm}$; tumour depth $>2 \mathrm{~mm}$; Clarks' level $\geq \mathrm{IV}$; location on the ear, lip, and sites not exposed to the sun, presence of perineural invasion, and poorly differentiated or undifferentiated histology), together with the nodal and metastatic status of the patient, can be used as a guide to treatment. ${ }^{7}$ Current UK guidelines for primary SCC recommend surgical excision, including Mohs micrographic surgery if appropriate, as the mainstay of treatment, but emphasise the need to be aware of the factors that could influence success when choosing treatment modality. ${ }^{8}$ However, in general, SCC treatment has not been thoroughly or rigorously studied. Our recent Cochrane systematic review of the treatment of primary non-metastatic $\mathrm{SCC}^{9}$ found only one randomised controlled trial that compared recurrence between groups receiving either adjuvant 13-cis retinoic acid and interferon alpha after initial surgery, or no adjuvant treatment. However, we found no randomised controlled trials that assessed the effectiveness of different interventions used commonly in clinical practice in the UK. ${ }^{9}$

This review looks at studies other than randomised controlled trials to assess the effectiveness of common treatment modalities used in everyday practice for SCC. This review aimed to provide an overview of the current evidence base, highlight areas in which the evidence base requires strengthening, and stimulate future research in the field.

\section{Methods}

The systematic review was conducted according to the MOOSE guidance for meta-analysis of observational studies. ${ }^{10}$ Details of the protocol for this systematic review are registered on PROSPERO (www.metaxis.com/prospero/full_doc.asp? RecordID=1450; web appendix 1).

\section{Search strategies}

We searched Medline (from 1948) and Embase (from 1980) up to December 2012 for relevant studies using search criteria for observational studies based on Scottish Intercollegiate Guideline Network filters (web appendix 2). ${ }^{11}$ We checked the bibliographies of included studies and recent review articles for additional articles that were relevant. Owing to the large number of studies and limited accuracy of translation, only studies published in English were retrieved.

\section{Inclusion and exclusion criteria}

We included all studies, other than randomised controlled trials, reporting one of the following items:

- Surgical excision

- Mohs micrographic surgery

- Radiotherapy (external radiotherapy, brachytherapy, and adjuvant radiotherapy)

- Laser irradiation

- Photodynamic therapy

- Cryotherapy

- Curettage and electrodesiccation

- Topical treatments (fluorouracil and imiquimod)

- Other chemotherapy used to treat previously untreated invasive squamous cell carcinoma of the skin, which was non-metastatic at presentation.

Based on our previous Cochrane systematic review, the main outcomes of interest were recurrence of SCC during follow-up from one month to 10 years after treatment, and quality of life. Secondary outcomes were initial response to treatment, cosmetic appearance, or death due to disease. We excluded studies for which we were unable to extract data for primary non-metastatic SCC. These included studies containing data for mixed populations of SCC and basal cell carcinoma, previously treated and untreated SCCs, or primary and metastatic SCCs. Studies in which separate data were not reported for different treatment modalities were also excluded. Owing to the large number of studies, studies reporting outcomes after surgical excision and Mohs micrographic surgery were only included if there were 20 or more eligible participants, unless they were restricted to a specific anatomical location, such as periorbital or auricular sites.

\section{Study selection and data extraction}

Three review authors (LL, FB-H, JL-B) independently checked the titles and abstracts of studies that potentially met the inclusion criteria. Studies that clearly did not refer to treatment of SCC of the skin were excluded. The full text was obtained for those studies that potentially fulfilled the inclusion criteria or for which the scope was unclear. Any disagreements were resolved through discussion between the authors. Data were extracted independently by two reviewers (LL, and JB or AA) and entered onto a standardised, pre-piloted data extraction form for assessment of study quality and evidence synthesis. A third author (JL-B or FB-H) resolved any discrepancies.

\section{Quality of reporting and risk of bias}

We evaluated the relative reporting quality of each study using a self developed tool based on criteria suggested by Joerg Albrecht for reporting case series and case reports (web appendix 3). ${ }^{12}$ Case series and open label studies were scored for the number of reporting quality items present and arbitrarily rated as being of poor (score 0-3), intermediate (4-7), or good quality (8-10). For those studies in which pharmaceutical preparations were an integral part of the treatment modality, we also recorded the declaration of sponsorship by a pharmaceutical manufacturer. 


\section{Data analysis}

For each study, we calculated raw proportions using the number of events divided by the total number of people in the study. Variances of the raw proportions were stabilised using the Freeman-Tukey variant of the arcsine square root transformation. ${ }^{13} \mathrm{We}$ did pooled analyses on the transformed quantity using a random effect model, to allow for heterogeneity resulting from inherent biases within the studies. Analyses were conducted using StatsDirect version 2. We were not able to directly allow for differences in length of follow-up using time to an event as an outcome measure, owing to lack of such data in the papers. However, we performed a subgroup analysis where possible, comparing the outcomes in studies that gave the mean follow-up as less than two years, between two and five years, and greater than five years.

To examine the effect of removing studies with greatest potential for risk of bias, we conducted a sensitivity analysis where possible by repeating the analysis with data from selected papers meeting at least three of the following criteria: 50 or more SCCs reported, mean follow-up greater than three years, recurrence type specified, scoring 8-10 on our reporting quality assessment. Adverse events and cosmetic appearance outcomes were described qualitatively.

\section{Results}

The searches identified 3826 publications after removal of duplicates, of which 451 were potentially eligible based on their titles; on review of the abstracts, 161 records were not relevant to the review. Of 290 full text articles assessed for eligibility, 172 were excluded, mainly because of lack of separable primary SCC data, leaving 118 that were included in the review (fig $1 \Downarrow$ ). The review included 106 non-comparative studies and 12 single case reports, which were included due to a lack of more robust study designs for particular interventions. Four studies reported outcomes for more than one treatment modality. Web appendix 3 shows full details of the studies, including details of the methodology, types of SCC included, and quality of reporting.

Figure $2 \Downarrow$ summarises the risk of bias for the studies. Forty eight per cent of studies were evaluated as having collected data retrospectively and $36 \%$ prospectively; the remaining studies could not be evaluated with regard to the design owing to the lack of sufficient information reported in the publications. Overall, $41 \%$ of studies were assessed as being at high or unclear risk of attrition bias due to analyses not accounting for losses to follow-up. Selection of a specific treatment modality on the basis of tumour or patient characteristics was assessed as presenting a high risk of bias in $54 \%$ of the studies, with low risk in $15 \%$. Risk of bias relating to selection could not be assessed in the remaining $31 \%$ of included studies because of insufficient reporting in the publications.

Overall, we classified $13 \%$ of the case series as being of poor reporting quality, $56 \%$ as intermediate quality, and $30 \%$ as high quality. Of 24 studies in which topical or systemic treatments were reported, seven (29\%) received some form of sponsorship from a pharmaceutical company but did not declare that the sponsor had had no involvement in the design, results and analysis of the study.

\section{Surgical excision}

We included 12 studies (1144 patients). Local recurrence during follow-up after surgical excision ranged from $0 \%$ to $15 \%^{14-25}$ (table $1 \Downarrow$ ), with an estimate of overall pooled recurrence of $5.4 \%$ (95\% confidence interval $2.5 \%$ to $9.1 \%, \mathrm{I}^{2}=81 \%$; fig $3 \Downarrow$ ).
Duration of follow-up varied between the studies. One study had a mean follow-up period of less than two years (16 months), with local recurrence of $1.8 \%$ of surgically excised SCCs of the head and neck region. ${ }^{18}$ In those studies with mean follow-up between two and five years (736 patients), recurrence ranged from $0 \%$ to $13.0 \%$, with a pooled estimate of recurrence of $5.0 \%$ (95\% confidence interval $2.3 \%$ to $8.3 \%, \mathrm{I}^{2}=62 \%$ ). ${ }^{14-16} 19-212325$ One of the 12 surgical excision studies had a minimum follow-up of five years and reported no local recurrences of 86 surgically excised SCCs at various sites. ${ }^{17}$ Three studies reported recurrence of $4.8 \%$ for eyelid SCCs,${ }^{25} 10.5 \%$ for trunk and extremity SCCs, ${ }^{22}$ and $15.3 \%$ for SCCs of the pinna, ${ }^{24}$ but did not specify how long patients were followed.

SCCs in the ear region were associated with highest recurrence rates. Three studies $(n=261)$ in which SCCs of the pinna were surgically excised gave a pooled average local recurrence of $14.1 \%$ (95\% confidence interval $10.2 \%$ to $18.5 \%, \mathrm{I}^{2}=0 \%$ ). ${ }^{20} 2324$ This recurrence was significantly higher than the lower pooled average of $3.2 \%\left(1.5 \%\right.$ to $\left.5.5 \%, \mathrm{I}^{2}=57 \%\right)$ for studies $(\mathrm{n}=916)$ in which SCCs at other sites were included (figs $4 \Downarrow$ and $5 \Downarrow){ }^{14-19} 212225$ We noted a non-significant increase in local recurrence with increasing SCC diameter in one series. There were local recurrences in $12.2 \%$ ( $4.6 \%$ to $24.7 \%$ ) of 49 lesions smaller than $10 \mathrm{~mm}$ in diameter, $14.3 \%$ (7.8\% to $23.2 \%)$ of 91 lesions $10-30 \mathrm{~mm}$ in diameter, $21.7 \%$ (7.4\% to $43.7 \%$ ) of 23 lesions $30-40 \mathrm{~mm}$ in diameter, and $42.8 \%$ (9.9\% to $81.6 \%$ ) of seven tumours greater than $40 \mathrm{~mm}$ in diameter. ${ }^{24}$

Sensitivity analysis of the four papers meeting our criteria for studies at lowest risk of bias had no significant effect on local recurrence $(4.2 \%$ (95\% confidence interval $0.6 \%$ to $10.8 \%$ ), $\left.\mathrm{I}^{2}=81.4 \%\right) .{ }^{17-19}{ }^{23}$ Recurrence in regional lymph nodes after surgical excision of SCC was reported in eight series (comprising of 786 patients), ranging from $0 \%$ to $9.7 \%$, ${ }^{14} 16182021232426$ with pooled average recurrence of $4.4 \%$ ( $2.4 \%$ to $6.9 \%, \mathrm{I}^{2}=50 \%$; fig $6 \Downarrow$ ). Sensitivity analysis in which only the three papers considered at lowest risk of bias were included had no significant effect on regional recurrence $(4.6 \%$ $(1.3 \%$ to $\left.10.0 \%), \mathrm{I}^{2}=72 \%\right) .^{182326}$

One study (108 patients) ${ }^{18}$ had a mean duration of follow-up of less than two years, with $0.1 \%$ recurrence $(95 \%$ confidence interval $0 \%$ to $5.1 \%$ ). In four studies, ${ }^{14} 162126$ specified mean follow-up duration was between two and five years, with a pooled average recurrence of $3.6 \%\left(1.9\right.$ to $\left.5.9, \mathrm{I}^{2}=11 \%\right)$. None of the studies had a mean follow-up longer than five years, and in three papers, follow-up duration was either not specified or given as a broad range..$^{20} 24$

In those series that only included treatment of SCCs located around the ear, the pooled average regional recurrence was $7.7 \%$ (95\% confidence interval $4.8 \%$ to $11.2 \%, \mathrm{I}^{2}=0 \%$ ). ${ }^{2023}{ }^{24}$ This proportion was significantly greater than the pooled average regional recurrence of $2.9 \%$ (1.4\% to $5.0 \%, \mathrm{I}^{2}=27 \%$ ) for the five remaining studies that included other head and neck locations (figs $7 \Downarrow$ and $8 \Downarrow$ ). ${ }^{14} 16182126$

We found two studies that reported distant metastases after surgical excision. Of 211 patients with SCCs at various sites who were followed up for at least a year, only one developed distant metastasis. ${ }^{27}$ There were no distant metastases in any of 35 patients with periocular SCC during a mean follow-up period of 31.1 months. ${ }^{16}$

In four articles (comprising 146 patients), recurrence was reported but not defined as being local, regional, or distant. Two of these studies had mean follow-up periods greater than five years, with pooled average recurrence of $5.4 \%$ (95\% confidence interval $0.7 \%$ to $27.6 \%$ ). ${ }^{28}{ }^{29}$ There were no reported recurrences 
in the study in which mean follow-up was less than five years. ${ }^{30}$ The fourth study included 13 patients with stage I or II SCC of the external ear, with a relatively high recurrence of $61.5 \%$ (31.6\% to $86.1 \%$ ) during follow-up ranging from six months to 20 years. $^{31}$

From analysis of eight studies comprising 485 patients with primary SCC, deaths attributable to disease ranged from $0 \%$ to $8.1 \%$ during follow-up, with a pooled average of $4.1 \%(95 \%$ confidence interval $1.7 \%$ to $7.6 \%, \mathrm{I}^{2}=58 \%$; fig $\left.9 \Downarrow\right) .^{14} 161720-2329$ Three studies with a follow-up period specified as between two and five years ${ }^{141621}$ had a significantly lower pooled average of $0.8 \%\left(0.1 \%\right.$ to $\left.2.5 \%, \mathrm{I}^{2}=0 \%\right)$ than the two studies with follow-up of more than five years from which the pooled average percentage of patients dying from their disease was $8.6 \%(4.7 \%$ to $13.6 \%) .{ }^{17}{ }^{29}$ In three papers, duration of follow-up was not specified or was given as a range only. ${ }^{2022}$ No deaths were reported in either of the two included studies in which SCCs of the eyelid were surgically excised. ${ }^{1621}$

Incompleteness of surgical excision was reported in 11 studies (comprising 2343 excisions). Overall, the pooled average estimate of incomplete excisions was $8.8 \%$ (95\% confidence interval $5.4 \%$ to $13.0 \%, \mathrm{I}^{2}=89 \%$; table $2 \Downarrow$, fig $10 \Downarrow){ }^{14} 171923262832-36$ Definitions of incomplete excision within the studies were not consistent. These were based on the presence of tumour cells at the surgical margin, ${ }^{26} 323435$ the presence of residual tumour at or within $1 \mathrm{~mm}$ of the lateral or deep margins of the excised specimen, ${ }^{28}$ tumour within one microscopic high-power field $(0.5 \mathrm{~mm}),{ }^{33}$ and the presence of tumour at or "close to" the margin of the resected specimen. ${ }^{36}$ Excision margins used varied. One prospective study used margins of $2 \mathrm{~mm}$ to more than $10 \mathrm{~mm},{ }^{34}$ with $6.2 \%$ of tumours being incompletely excised ( $4.2 \%$ to $8.8 \%)$. In another prospective series with no SCCs incompletely excised, excision margins were based on the clinical diagnosis and surgeon's preference. ${ }^{33}$ The other studies assessing incomplete excision were retrospective reviews. Retrospective reviews that specified the excision margin used margins between $3 \mathrm{~mm}$ and 6 mm. ${ }^{1926283235}$ The highest percentage of incompletely excised tumours was observed after excision of periorbital lesions with a $5 \mathrm{~mm}$ margin, with $25 \%$ being incompletely excised $(15.3 \%$ to $37.0 \%){ }^{19}$

None of the included studies reported SCC specific quality of life, cosmetic appearance, and adverse event data.

\section{Mohs micrographic surgery}

Sixteen studies reported outcomes after Mohs micrographic surgery. In a seminal series of papers, Mohs reported cure rates at five years for previously untreated SCCs of the trunk and extremities $(95.7 \%)^{37}$; of the ear $(96.6 \%)^{38}$; of the face, scalp, and neck $(97.8 \%)^{37}$; of the eyelid $(98.5 \%)^{39}$; and of the nose $(98.8 \%){ }^{37}$ A pooled cure rate at five years for the 2133 SCCs at all sites was $97.4 \%$ (95\% confidence interval $96.2 \%$ to $98.3 \%$, $\left.\mathrm{I}^{2}=48 \%\right)$.

Ten studies reported local recurrence, ${ }^{18}{ }^{40-48}$ ranging from $0 \%$ (95\% confidence interval $0 \%$ to $36.9 \%$ ) in one small study including eight periorbital $\mathrm{SCCs}^{40}$ to $5.7 \%(1.9 \%$ to $12.9 \%)$ in a study of auricular SCCs. ${ }^{47}$ For the 10 studies (comprising 1572 participants), the pooled average local recurrence was $3.0 \%$ ( $2.2 \%$ to $3.9 \%, \mathrm{I}^{2}=0 \%$; table $3 \Downarrow$, fig $11 \Downarrow$ ). Sensitivity analysis including only the six studies meeting the prespecified criteria had no significant effect on local recurrence $(2.7 \% ; 1.9 \%$ to $\left.3.7 \%, \mathrm{I}^{2}=0 \%\right){ }^{18} 4143-4548$

In one study with specified mean follow-up of less than two years, ${ }^{46}$ recurrence was $3.5 \%$ (95\% confidence interval $1.3 \%$ to
7.5\%). This proportion did not differ significantly from the average recurrence of $2.8 \%\left(2.0 \%\right.$ to $\left.3.9 \%, \mathrm{I}^{2}=0 \%\right)$ in seven studies with mean follow-up of between two and five years, ${ }^{18} 40-434547$ and $3.1 \%$ (1.4\% to 5.4\%) in the two studies with mean follow-up greater than five years. ${ }^{44} 4$

Six studies reported recurrence in the regional lymph nodes after treatment with Mohs micrographic surgery..$^{18} 404134549$ On pooled analysis (comprising 1162 patients), the average regional recurrence was $4.2 \%$ (95\% confidence interval $2.3 \%$ to $6.6 \%$, $\mathrm{I}^{2}=56 \%$; fig $\left.12 \Downarrow\right)$. There was no significant effect on regional recurrence in the sensitivity analysis, which included only the four studies meeting the criteria, ${ }^{18} 414345$ with average recurrence of $3.2 \%$ (1.9\% to $\left.5.0 \%, \mathrm{I}^{2}=29 \%\right)$.

Five studies ${ }^{18} 40414345$ specified mean follow-up between two and five years, with a pooled regional recurrence of $3.4 \%(95 \%$ confidence interval $1.8 \%$ to $5.3 \%, \mathrm{I}^{2}=34 \%$ ). None of the studies had mean follow-up greater than five years.

One study reported no distant metastases during at least five years' follow-up in 229 patients treated with Mohs micrographic surgery. ${ }^{44}$ In a case series of 87 auricular SCCs, no distant metastases were reported during a mean follow-up period of 34.6 months. ${ }^{47}$ One smaller series of 48 SCCs treated by Mohs micrographic surgery observed one patient with distant metastasis during a mean follow-up of 3.4 years. ${ }^{43}$ Another series including eight patients with periocular SCC also noted one patient with metastases to the lung, ${ }^{40}$ although the authors presumed that this patient had subclinical spread of tumour before treatment with Mohs micrographic surgery, because there was no evidence of local recurrence.

Five studies (766 patients) did not define recurrence as being local, regional, or distant. ${ }^{31}{ }^{50-53}$ These five studies had a pooled average unspecified recurrence of $4.7 \%$ (95\% confidence interval $0.7 \%$ to $11.7 \%, \mathrm{I}^{2}=81 \%$; fig $13 \Downarrow$ ). The highest proportion of unspecified recurrences was seen in a small series of 16 external ear SCCs during follow-up of between six months to 20 years, in which $31.2 \%$ of tumours recurred $(11.7 \%$ to $58.7 \%){ }^{31}$

Three studies (735 patients) specified mean duration of follow-up as being between two and five years. ${ }^{51-53}$ For these studies, the average unspecified recurrence was $2.2 \%(95 \%$ confidence interval $0.3 \%$ to $5.4 \%, \mathrm{I}^{2}=61 \%$ ). The remaining studies $^{3150}$ did not specify the mean duration of follow-up.

Four studies with mean follow-up of between two and five years reported deaths attributable to SCC, ${ }^{404} 4547$ with an average of $1.1 \%$ (95\% confidence interval $0.2 \%$ to $2.6 \%, \mathrm{I}^{2}=49 \%$ ) of the 941 eligible patients dying from disease on pooled analysis (fig $14 \Downarrow$ ). One of the included studies reported a relatively high proportion of deaths compared to the other studies. It was a small series of eight patients with periocular SCCs, one of whom developed regional metastases and lung metastases without evidence of local recurrence, indicating that the tumour had spread subclinically before treatment. ${ }^{40}$

None of the included studies reported separate SCC data for quality of life, cosmetic outcomes, or adverse events.

\section{External radiotherapy}

We found 14, mostly retrospective, studies in which a total of 1018 primary SCCs were treated with external

radiotherapy. ${ }^{15} 202754-64$ Seven studies (comprising 761 patients) reported local recurrence after external radiotherapy, with pooled average local recurrence of $6.4 \%$ (95\% confidence interval $3.0 \%$ to $11.0 \%, I^{2}=76 \%$; table $4 \Downarrow$; fig $\left.15 \Downarrow\right)$. ${ }^{1525455575864}$ Three studies 
were included in the sensitivity analysis, ${ }^{55}{ }^{56}$ with no significant effect on local recurrence $\left(7.3 \%, 2.1 \%\right.$ to $\left.15.4 \%, \mathrm{I}^{2}=87 \%\right)$.

The four studies with a mean follow-up period between two and five years ${ }^{1555} 5864$ had a pooled average recurrence of $6.1 \%(95 \%$ confidence interval 2.2 to $11.7, \mathrm{I}^{2}=85 \%$ ). None of the studies had mean follow-up greater than five years, and three studies did not specify duration of follow-up or gave it as a broad range. ${ }^{20} 5457$

In one study, location in the ear and scalp region was found to be significantly associated with relapse of tumour compared with other sites $(\mathrm{P}=0.025) .{ }^{64}$ Age and tumour size were also significantly correlated with risk of relapse in this study $(\mathrm{P}=0.012$ and $\mathrm{P}<0.0001$, respectively). There was a trend towards better outcome with well-differentiated tumours, although this finding was not significant $(\mathrm{P}=0.1)$. Two studies (with 155 patients in total) only assessed nasal SCCs, with a pooled average local recurrence of 5.6\% (95\% confidence interval $2.6 \%$ to $9.7 \%) .{ }^{54}$ In another two small studies (19 patients) that only included SCCs of the pinna, the pooled average local recurrence was $20.3 \%(0.0 \%$ to $64.6 \%),{ }^{20} 57$ although the wide confidence intervals suggested that this recurrence was not significantly different from recurrence of nasal SCCs.

Regional lymph node failure was also reported in three studies (comprising 272 patients in total), ${ }^{20} 5864$ giving an average regional recurrence of $2.6 \%$ on pooled analysis ( $95 \%$ confidence interval $0.04 \%$ to $8.9 \%, \mathrm{I}^{2}=70 \%$; fig $16 \Downarrow$ ). In both larger studies ${ }^{58}{ }^{64}$ - which included patients with SCCs of the nose and at various sites, respectively-the mean duration of follow-up was between two and five years. In the third study, there were only two eligible patients with SCC of the pinna, one of whom developed metastasis. ${ }^{20}$ Excluding this study from the analysis had no effect on the outcome.

One study reported locoregional recurrence after either local radiotherapy alone, or after local radiotherapy plus radiotherapy to first echelon lymph nodes. ${ }^{59}$ Overall recurrence in the 37 SCCs treated with local radiotherapy alone was 30.0\% (95\% confidence interval $15.9 \%$ to $47.0 \%$ ). Recurrence ranged from $14.3 \%$ ( $0.3 \%$ to $57.9 \%$ ) for the seven T2 tumours to $29.2 \%$ ( $12.6 \%$ to $51.1 \%$ ) for the $24 \mathrm{~T} 3$ tumours, to $50 \%$ (11.8\% to $88.2 \%$ ) for the six T4 tumours. However, with wide overlapping confidence intervals, statistical significance cannot be inferred from these differences. Of five T4 tumours treated with local radiotherapy plus nodal radiotherapy, there was one recurrence (20\%, $0.5 \%$ to $71.6 \%)$.

Recurrence was not defined as local, regional, or distant in another six studies. ${ }^{27} 56{ }^{60-63}$ Pooled data from 220 treated SCCs from the studies gave an average recurrence of $4.8 \%(95 \%$ confidence interval $0.6 \%$ to $12.8 \%, \mathrm{I}^{2}=70 \%$; fig $17 \Downarrow$ ). Two of the studies ${ }^{56}{ }^{63}$ had a mean duration of follow-up of less than two years with pooled recurrence of $27.2 \%$ (2.0\% to $89 \%$ ). However, the number of patients was very small $(n=5)$, and in one study ${ }^{63}$ only $\mathrm{T} 4$ tumours were treated, with recurrence in two of three patients. Average recurrence in the two studies with specified mean duration of follow-up of between two and five years was $6.1 \%$ (44 patients, $0 \%$ to $22.6 \%$ ). ${ }^{60}{ }^{62}$ There were no studies in which the mean follow-up period was greater than five years, with unspecified mean follow-up duration on the remaining two studies. ${ }^{27} 61$

We found five studies including 191 patients that reported deaths as a result of SCC, ${ }^{20} 5861-63$ with an average of $9.1 \%$ of patients dying from their disease on pooled analysis $(95 \%$ confidence interval $1.4 \%$ to $22.8 \%, \mathrm{I}^{2}=79 \%$; fig $\left.18 \Downarrow\right) .260636465$ The greatest proportion of deaths was observed in a study of advanced $\mathrm{T} 4$ tumours in which two of three patients with eligible SCCs died $(66 \%, 9.4 \%$ to $99.1 \%),{ }^{63}$ during a mean follow-up period of 14 months. For studies with mean duration of follow-up between two and five years, the average recurrence was $4.8 \%$ (119 patients, $1.6 \%$ to $9.8 \%) .{ }^{58}{ }^{62}$ None of the studies had mean duration of follow-up greater than five years.

SCC specific data for cosmetic appearance and adverse events were not available from any of the included studies.

\section{Brachytherapy}

Six studies (comprising 88 SCCs) reported recurrence after brachytherapy (table $5 \Downarrow$; fig $19 \Downarrow$ ), ${ }^{65-70}$ giving a pooled average local recurrence of $5.2 \%$ (95\% confidence interval $1.6 \%$ to $\left.10.5 \%, \mathrm{I}^{2}=0 \%\right)$. Of these studies, four were prospective reports $(35 \mathrm{SCCs})^{65676870}$ and two were retrospective (53 SCCs) ${ }^{66} 69$ with varying follow-up periods from an average of 9.6 month $\mathrm{s}^{68}$ up to a median of 55 months. ${ }^{66}$ Four studies had no recurrences during follow-up. ${ }^{65-68}$ In the largest study, a retrospective review in which 48 SCCs at various sites were treated with a superficial radon mould, there were two local recurrences of hand and scalp SCCs at 10 and six months, respectively. ${ }^{69}$ The other reported SCC recurrence occurred 23 months after high dose rate brachytherapy with a ${ }^{192} \mathrm{Ir}$ surface mould, and was a $4 \mathrm{~cm}$ tumour located on the frontal area. ${ }^{70}$ No patients in this study developed regional or distant metastases after treatment.

One study reported that four $(8.3 \%)$ of 48 SCCs treated with a radon mould persisted after initial treatment and required treatment by other methods to ablate the lesions. ${ }^{69}$ The study authors attributed their high failure rate to the inclusion of tumours with a high volume, or with a thickness was greater than $4 \mathrm{~mm}$, which had been inappropriately treated by brachytherapy.

None of the included studies reported on deaths attributable to disease. Furthermore, SCC specific data for cosmetic appearance and adverse events were not available from any of the included studies.

\section{Adjuvant radiotherapy}

We included nine studies which used adjuvant radiotherapy with surgery to treat previously untreated SCCs that were non-metastatic at presentation. Tables $6 \Downarrow$ and $7 \Downarrow$ show details of these studies and pooled outcome data.

Adjuvant radiotherapy was administered for perineural invasion in five retrospective studies (comprising 22 patients). ${ }^{71-75}$ In one of these studies, ${ }^{73}$ local recurrence occurred in two of six patients with asymptomatic perineural invasion in nerve branches of 0.4 $\mathrm{mm}$ diameter. All excised SCCs had clear surgical margins of at least $3 \mathrm{~mm}$. One of these patients also had regional metastasis, and the other had distant metastasis after treatment. Metastasis to the skull after one year of treatment was reported in one patient with symptomatic perineural invasion, affecting the supraorbital nerve in a further series. ${ }^{72}$ In the other three studies, two included patients with asymptomatic perineural invasion in unnamed nerves ${ }^{7174}$ and one involved named cranial nerves. ${ }^{75}$ None of these three studies reported recurrence after treatment during follow-up ranging 10.4-104.8 months.

Four studies (47 patients) reported outcomes after adjuvant radiotherapy for SCCs other than those with perineural invasion. These included patients with pinna SCCs,${ }^{20}$ trunk and extremity SCCs, ${ }^{76} 77$ and aggressive SCCs after a cardiothoracic

transplant. ${ }^{78}$ The basis on which patients were selected to receive adjuvant radiotherapy as opposed to surgical monotherapy was not clearly identified in any of the studies. Three of the included 
studies were retrospective, ${ }^{20} 777^{78}$ and the other a prospective assessment of adjuvant radiotherapy to draining lymph nodes in patients with trunk and extremity SCCs $(50 \%$ of which developed in an area of erythema ab igne).$^{76}$ Adjuvant radiotherapy was administered to the draining regional lymph nodes in both studies of trunk and extremity SCCs. ${ }^{76} 77$ The irradiation field was not specified in the other studies. ${ }^{20} 78$ Three of the four studies reported recurrence after treatment during follow-up ranging from less than one year to more than three years. In the prospective study, three (12\%) of 26 patients developed local recurrence six to 12 months after treatment, with regional recurrence developing in one patient. No distant metastases were reported during follow-up of up to 12 months. ${ }^{76}$ Local recurrence was also reported in two of six patients who developed SCC after cardiothoracic transplantation, one of whom also developed regional recurrence. Another patient in this series also had a systemic relapse, despite local control of their SCC. ${ }^{78}$

One study reported two deaths (of four eligible patients) attributable to SCC at six and 11 months after treatment for perineural invasion involving named cranial nerves. Both patients had intracranial disease extending through a peripheral foramen but had refused an intracranial operation. ${ }^{75}$ No deaths attributable to SCC after adjuvant radiotherapy for perineural invasion were reported in any of the remaining three studies (16 patients). ${ }^{71} 7374$

Three studies (comprising 21 patients) investigated adjuvant radiotherapy of other SCCs and had data on patient deaths. One study reported the deaths of three of six patients who had SCCs after undergoing a cardiothoracic transplantation between eight months and 54 months after diagnosis. ${ }^{78}$ No deaths were reported in the other studies, ${ }^{20}{ }^{77}$ which included patients with SCCs of the trunk and extremities, and of the pinna. Table 7 presents pooled data.

In one study, initial failure of wide local excision and adjuvant radiotherapy to control disease locally was reported in one patient (of six), ${ }^{78}$ who died 15 months after treatment.

Mild erythema, dry and moist desquamation, and alopecia of hair bearing areas in the irradiated field after adjuvant radiotherapy were the most commonly reported adverse events in included studies. ${ }^{71}{ }^{72} 76$ Single adverse events recorded were wound infection and serous otitis media, ${ }^{71}$ self limiting mucositis, radiation dermatitis and residual mild xerostomia, ${ }^{74}$ and reactive lymphoedema of the leg. ${ }^{76}$

\section{Curettage and electrodesiccation}

Table $8 \Downarrow$ shows details of the included studies. Only one small retrospective study of 15 patients with SCC of the pinna described local and regional recurrence separately after treatment by curettage and electrodesiccation. ${ }^{20}$ Of the 15 patients included, three had local recurrence (20\%), of whom one (7\%) developed regional disease and two died as a result of their disease.

Seven studies (comprising 1131 patients) which included SCCs from various sites, reported on recurrence after curettage and electrodesiccation but did not specify the nature of the recurrence ${ }^{27} 3060$ 79-82 ; on pooled analysis, average recurrence was $1.7 \%$ (95\% confidence interval $0.6 \%$ to $3.4 \%, \mathrm{I}^{2}=59 \%$; fig $20 \Downarrow$ ). We did not perform a sensitivity analysis as none of the studies met the criteria for this.

For the two studies ${ }^{30}{ }^{82}$ with specified mean follow-up periods between two and five years, the pooled recurrence was $4.5 \%$ (109 patients, $95 \%$ confidence interval $1.4 \%$ to $9.0 \%$ ). Just one study ${ }^{80}$ had a mean follow-up of more than 5 years, with recurrence in one of 29 patients ( $3.4 \%$; $0 \%$ to $17.8 \%)$. The remaining studies did not specifiy mean duration of follow-up.

Most of the treated SCCs in these series were small, with a total of $91 \%$ having a diameter less than $2 \mathrm{~cm}$ in the studies in which data about diameter was provided..$^{27} 607982$ Increased lesion size as a significant prognostic feature was observed in one study; recurrence in the 17 SCCs larger than $2 \mathrm{~cm}$ was $11.8 \%(95 \%$ confidence interval $1.4 \%$ to $36.4 \%)$ compared with $0.4 \%(0.0 \%$ to $2.1 \%$ ) in the 264 SCCs smaller than $2 \mathrm{~cm}^{60}$ One study separated results according to the number of treatment cycles used with no recurrences after either two or three cycles. ${ }^{79}$ Two studies specified the number of cycles of electrodesiccation as either double ${ }^{80}$ or triple, ${ }^{81}$ but this information was not reported for the remaining studies.

Cosmetic outcome was reported in just one of the included studies (41 patients), ${ }^{81}$ and rated as 'good' in $29 \%$ of SCCs, 'satisfactory' in 54\% or 'poor' in $17 \%$, although no definition of each of these terms was provided and it was unclear how soon after treatment the assessment of cosmesis was made. None of the included studies reported adverse event data.

\section{Cryotherapy}

There were eight studies (comprising 273 patients) that described recurrence after cryotherapy. ${ }^{83-90}$ Only one study reported recurrence after cryotherapy ${ }^{90}$ in one of the 34 included patients with SCCs at any site who were treated with a double freeze-thaw cycle using liquid nitrogen. Data from the 273 patients in the eight studies gave a pooled average recurrence of $0.8 \%$ (95\% confidence interval $0.1 \%$ to $2.2 \%, \mathrm{I}^{2}=0 \%$; fig $21 \Downarrow$ ). Table $9 \Downarrow$ contains details of prognostic features of the SCCs included. Sensitivity analysis was not conducted because only one study met our prespecified criteria, ${ }^{89}$ with no reported recurrences (53 patients; $0 \%$ to $6.7 \%$ ).

In five studies, ${ }^{83848688} 89$ the mean duration of follow-up was between two and five years, with a pooled average recurrence of $0.4 \%$ (221 patients; $95 \%$ confidence interval $0 \%$ to $1.7 \%$, $\mathrm{I}^{2}=0 \%$ ). None had a mean follow-up of greater than five years, and for three studies, ${ }^{85} 8790$ follow-up was given as a range only.

An overall cure rate of $97 \%$ was reported after either a single or double freeze-thaw cycle with liquid nitrogen in a retrospective series of $563 \mathrm{SCCs}$ at any site that were treated over a 23 year period. ${ }^{91}$ Because the authors did not define "cure," this rate could include lesions that failed to respond to the initial treatment in addition to those which recurred. The duration of follow-up was not specified.

Failure to respond to initial treatment was reported in one (3\%) of 34 patients in one prospective series. ${ }^{90}$ A double freeze-thaw cycle was used to treat the original SCC, a $5 \mathrm{~mm}$ lesion on the scalp, which showed little clinical response despite a second course of cryotherapy two months after the initial treatment.

None of the studies that reported cosmetic appearance and adverse events separated results for SCCs and basal cell carcinomas, but presented results for non-melanoma skin cancers as a whole.

\section{Photodynamic therapy}

There were 14 small prospective studies (comprising 297 patients) that evaluated the response of SCCs to photodynamic

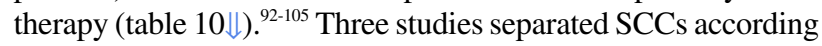
to level or depth of invasion, ${ }^{92} 9598$ and one was a non-randomised two-arm comparison of topical photodynamic therapy either with or without a 5\% glycolic acid penetration enhancer. ${ }^{97}$ On pooled analysis, an average of $72.0 \%$ of treated 
lesions appeared to respond completely to treatment $(95 \%$ confidence interval $61.5 \%$ to $81.4 \%, \mathrm{I}^{2}=71 \%$; fig $22 \Downarrow$ ). Five studies specified that histological assessment of at least some of the treated areas was done to confirm apparent clinical response. ${ }^{93} 95102104105$

In eight of the included studies, SCCs that had apparently completely responded to photodynamic therapy initially were observed for recurrence. ${ }^{94-96} 98$ 102-105 Pooled recurrence data from these studies (119 SCCs) gave an odds of recurrence of $26.4 \%$ (95\% confidence interval $12.3 \%$ to $43.7 \%, \mathrm{I}^{2}=72 \%$; fig $23 \Downarrow$ ).

Table $11 \Downarrow$ summarises the results. Mean duration of follow-up ranged from six months (at which time the trial was abandoned due to recurrence in more than $50 \%$ of lesions) ${ }^{102}$ to 38 months. ${ }^{94}$

One study evaluated cosmetic appearance on a scale of 1 to 4 (excellent to poor) at three months and 24 months after treatment,${ }^{98}$ with high agreement between patient and investigator scores for both time points. At three months, $4 \%$ of 46 treated microinvasive (Clark level II) and invasive (Clark level III/IV) SCCs were assessed as having "excellent" cosmetic appearance, $48 \%$ assessed as "good," $44 \%$ assessed as "fair," and $4 \%$ assessed as "poor." By 24 months, of 31 assessable treated lesions, $10 \%$ were rated as having poor cosmetic appearance, $48 \%$ as fair, $36 \%$ as good, and $6 \%$ as excellent. Tumour thickness, depth of dermal penetration, and the degree of cell atypia were found by the authors to be univariate predictors of outcome (Kruskal-Wallis test $\mathrm{P}<0.01$ ). One smaller study also evaluated cosmetic appearance on a scale of 1 (very good) to 4 (poor). Five treated lesions (56\% of nine patients) were assessed as having a very good appearance, three (33\%) assessed as good, and one (11\%) assessed as fair. ${ }^{105}$ None was deemed to have poor appearance in this study. Two further studies described cosmetic results as "very satisfactory" 97 or "very good" with no scar formation and only transient residual hypopigmentation or hyperpigmentation. ${ }^{94}$

Separate SCC data for adverse events were not available from the included studies.

Data for laser therapy, imiquimod, 5-fluorouracil, interferon, retinoids, and chemotherapy are presented in web appendix 4 .

\section{Discussion}

This is the first systematic review to our knowledge that assesses the effectiveness of all treatment modalities for primary non-metastatic SCC, giving an overview of current evidence from non-randomised studies.

Caution needs to be exercised when comparing outcomes after different treatment modalities, owing to the limitations of the included studies. Surgery with a predefined excision margin is the treatment of choice for most cutaneous SCCs, with Mohs micrographic surgery being recommended for SCCs considered to be higher risk or in cosmetically sensitive areas. Our pooled analysis suggests lower rates of local recurrence and deaths attributable to disease after Mohs micrographic surgery, despite the fact that tumours treated by this method are likely to be at higher risk-although there have been no randomised controlled trials to directly compare the two treatments. However, in our pooled analysis, regional recurrence was of a similar magnitude for both treatment modalities, which suggested subclinical spread of some higher risk tumours treated with Mohs micrographic surgery to regional lymph nodes at the time of treatment. Overlapping confidence intervals for average effect estimates for the different treatments suggested that apparent differences between treatments might not be significant. This finding accords with those of Chren and colleagues. ${ }^{106}$ In their large prospective cohort study of all primary non-melanoma skin cancers, they reported no significant difference in hazard of recurrence between surgically excised tumours and those treated with Mohs micrographic surgery.

In our pooled analysis of external radiotherapy, average local recurrence was slightly higher than that seen after conventional surgical excision, although the differences were probably not significant owing to overlapping confidence intervals. Average regional recurrence was lower than local recurrence, although these data were generated from just two studies ${ }^{58}{ }^{64}$ - other studies did not specify whether reported recurrences were local or regional failures, thus the true significance of this is unclear. The lower rates of local recurrence from the studies using brachytherapy could indicate the more superficial, lower risk nature of the included SCCs treated by this method. However, patient numbers were generally small and follow-up was limited (only a few months in some studies) and could be inadequate to detect later recurrences. The greater rates of recurrence, metastasis, and death from disease observed with adjuvant radiotherapy after surgical excision accords with other studies. ${ }^{107}$ However, numbers of patients in included studies were small and for SCCs that did not have perineural invasion, the reasons justifying the use of adjuvant radiotherapy was not always clear. The results could therefore reflect the selection of those SCCs with a particular poor prognosis, and the identification of prognostic factors that could benefit from adjuvant radiotherapy remains an area of uncertainty and one in which prospective studies are needed.

Lowest recurrence rates were observed after cryotherapy and after electrodesiccation and curettage, but most SCCs included in these analyses were small and considered to be low risk lesions. However, the evidence is poor to advocate their use in lesions considered at higher risk of recurrence and recurrent SCCs.

Based on our results, the use of photodynamic therapy to treat invasive SCCs cannot be advocated. Few studies confirmed histological clearance in apparently completely responsive SCCs, and in those that attempted to do so, residual tumour remained in several biopsies. Furthermore, more than a quarter of those tumours that had seemed to completely respond to photodynamic therapy initially recurred during follow-up.

Not all patients with SCC are amenable to surgical treatment or radiotherapy, and some are susceptible to multiple SCCs as a result of a genetic or immune predisposition. Such groups pose particular therapeutic challenges, and there is a growing need for effective topical or systemic agents that could be used in such groups. The current evidence for these agents to treat primary SCCs is largely anecdotal, based on single case reports or very small numbers of eligible patients in open label trials with limited follow-up and generally lacking recurrence data, but is an interesting area for further development as new insights into the pathogenesis and targeted therapies emerge.

Although we included quality of life as one of our outcomes, none of the included studies in this review measured this. Patient reported outcome measures (PROMs) have great potential to improve the quality of health services by providing validated evidence of health from the patient's perspective. Two recent systematic reviews ${ }^{108} 109$ of these measures in skin cancer showed that there have been limited evaluations of patient reported outcome measures that were specifically designed for patients with non-melanoma skin cancers. Furthermore, the questionnaires developed so far have not been perfect for assessing the quality of life in these particular patients. Nevertheless, the incorporation of patient reported outcomes will undoubtedly be important in the development of future 
clinical trials comparing treatments for SCC. These outcomes should also be able to capture quality of life issues that are important to patients with SCCs, including detailed assessment of cosmetic and functional outcomes at specific time points.

\section{Strengths and limitations of this systematic review}

Although we tried to be as thorough as possible in our literature search, it is inevitable that we failed to find relevant studies. Observational studies, and especially case series, are more difficult to identify from searching literature databases than randomised controlled trials. Observational studies are usually not identifiable from the title and are less consistently indexed according to study design in bibliographic databases; there is undoubtedly also an element of publication bias with these types of studies.

We did not review treatments of recurrent SCCs and tumours known to be metastatic at presentation. Many studies were excluded because they included previously treated relapsed tumours without separation of data from non-recurrent tumours. Such recurrent tumours could have different features to those that have not been treated previously-which makes them more likely to recur or be resistant to treatment.

Similarly, we did not specifically search for studies relating solely to the management of SCC in solid organ transplant recipients, although some of the studies did include such patients. Cutaneous SCC is an important cause of morbidity in this group of patients, and is associated with the likelihood of multiple tumours and a potentially more aggressive clinical course. ${ }^{110}$ This topic is therefore perhaps suitable for separate consideration and beyond the scope of this more general review. We found that mean follow-up periods were generally poorly reported and few studies reported mean follow-up of more than five years; therefore, assessment of recurrence according to duration of follow-up was limited in our review. When possible, we did subgroup analyses to compare outcomes in those studies with mean follow-up periods of less than two years, between two and five years, and greater than five years. Our main finding on subgroup analysis was that the proportion of deaths attributable to SCC was significantly greater for studies with a mean follow-up longer than five years after conventional surgical excision compared with studies with a shorter follow-up. Between $70 \%$ and $90 \%$ of recurrences and metastases occur within the first two years after treatment, ${ }^{4911112}$ and $95 \%$ within five years. ${ }^{112} 113$ Therefore, the results from our analysis probably represent the true recurrence up to five years of follow-up.

\section{Bias and quality of reporting}

Validated tools for assessing the risk of bias in non-randomised studies are limited, making the evaluation of study quality less objective than for randomised controlled trials. Owing to the lack of evidence in the literature specifically reviewing the assessment of case series, we have based our evaluation on a modified assessment tool on risk of bias from the Cochrane Collaboration, ${ }^{114}$ together with suggestions drawn up by Albrecht ${ }^{12}$ for improving the quality of case series. Albrecht's suggestions are based on a few published articles ${ }^{115-117}$ and Albrecht's own experience of systematic reviews of case series and reports. ${ }^{118}$

Most of the included studies were of limited methodological quality and prone to bias (fig 2), with variable patient mixes in terms of prognostic factors, overall disease severity, and duration of follow-up. Recruitment bias with selection of particular treatment modalities based on tumour or patient characteristics is a serious consideration for case series and was positively identified or was an unclear risk in $85 \%$ of the studies in this review. Therefore, we could not directly compare the effectiveness of different treatments. In $41 \%$ of studies, losses to follow-up were either incompletely reported or not mentioned, making it difficult to assess the risk of attrition bias.

\section{Stratification of risk}

A limited number of studies stratified outcomes according to particular prognostic indicators, although it was not possible to stratify results from data provided by most studies. SCC location in the ear was a poor prognostic feature, supported by our pooled analysis of data from studies that considered ear and other locations. We did not do a pooled analysis of other features considered high risk, owing to different reporting methods in the studies. Increased risk of recurrence with tumours greater than $2 \mathrm{~cm}$ was noted in some studies. ${ }^{24}{ }^{17} 49$ However, this finding was not supported by Mourouzis and colleagues ${ }^{26}$ with $60 \%$ of metastases originating in SCCs smaller than $2 \mathrm{~cm}$, nor by Dzubow and colleagues, ${ }^{46}$ who found a trend towards significance with tumours larger than $5 \mathrm{~cm}$ in diameter. Several studies showed the importance of SCC depth as a risk factor for recurrence. Mourouzis and colleagues did not observe any metastases in SCCs less than $2 \mathrm{~mm}$ in depth, ${ }^{26}$ in accordance with Brantsch and coauthors, ${ }^{45}$ who reported a significantly increased risk of metastases for SCCs greater than $2 \mathrm{~mm}$ thick. Griffiths and colleagues ${ }^{17}$ also reported a significant difference in thickness between SCCs in patients who died of their disease and those who did not. Poor differentiation was noted to be an adverse prognostic feature in two of the included studies, ${ }^{26}{ }^{49}$ with the presence of perineural invasion being significantly associated with a worse outcome in one of the series. ${ }^{49}$

There are currently no accurate prognostic models to stratify patients with SCC and to help guide clinical decisions, leading to a lack of uniformity in the management of the tumour. In 2010, the American Joint Committee on Cancer updated the staging system for SCC, incorporating high risk features into the tumour (T) classification. ${ }^{119}$ Although the update was an improvement on the previous classification, it was not without criticism. ${ }^{120-122}$ Alternative staging systems have been proposed in an attempt to stratify the large group of heterogeneous T2 tumours according to their prognostic features. ${ }^{113}{ }^{121}$ Although further validation work is required, these systems could be useful tools when designing future clinical trials.

We thank Alemayehu Amberbir (AA) and Joanna Browne (JB) who assisted with data extraction.

Contributors: LL, FB-H, WP, and JL-B contributed to the development of the review questions. WS and LL designed the searches. LL, FB-H, and JL-B assessed the eligibility of studies for inclusion, extracted data, and assessed risk of bias and quality of reporting. JL-B developed the statistical analysis. LL, FB-H, WP, and JL-B contributed to the analysis and interpretation of data. LL drafted the article and all other authors approved the final version, had full access to the data, and take responsibility for the integrity of the data and accuracy of the analysis. $\mathrm{LL}$ is the guarantor.

Funding: This systematic review presents independent research funded by the National Institute for Health Research (NIHR) under its Programme Grants for Applied Research funding scheme (RP-PG-0407-10177).

Competing interests: All authors have completed the ICMJE uniform disclosure form at www.icmje.org/coi_disclosure.pdf and declare: LL, $\mathrm{FBH}, \mathrm{WP}$, and JLB received support from the NIHR for the submitted 


\title{
Summary: surgical excision of SCCs
}

12 studies, mostly retrospective case series, of limited quality and with varying follow-up periods

Local recurrence varied owing to different time points assessed

Local recurrence average $5.4 \%$ (95\% confidence interval $2.5 \%$ to $9.1 \% ; 12$ studies, $n=1144$ )

Regional recurrence average estimate $4.4 \%$ (2.4\% to $6.9 \%$; eight studies, $n=786$ )

Ear location significantly associated with local and regional recurrence

Unspecified recurrence average $5.4 \%(0.7 \%$ to $27.6 \%$; two studies, $n=113)$

Death from disease average $4.1 \%(1.7 \%$ to $7.6 \%$; eight studies, $n=485)$

Increased proportion of deaths attributable to disease in studies with follow-up longer than five years compared with follow-up between two and five years (8.6\% (4.7\% to $13.6 \%$; two studies, $\mathrm{n}=149) v 0.8 \%(0.1 \%$ to $2.5 \%$; three studies, $\mathrm{n}=223)$ )

Incomplete excision average $8.8 \%(5.4 \%$ to $13.0 \% ; 11$ studies, $n=2343)$

\section{Summary: Mohs micrographic surgery of SCCs}

16 case series, prospective and retrospective

Local recurrence average $3.0 \%$ (95\% confidence interval $2.2 \%$ to $3.9 \% ; 10$ studies, $n=1572$ )

Regional recurrence average $4.2 \%$ (2.3\% to $6.6 \%$; six studies, $n=1162)$

Unspecified recurrence average $4.7 \%(0.7 \%$ to $11.7 \%$; five studies, $n=766)$

Death from disease average $1.1 \%(0.2 \%$ to $2.6 \%$; four studies, $n=941)$

\section{Summary: external radiotherapy of SCCs}

One prospective series and 13 retrospective series

Variation between studies for radiation source and length of follow-up

Local recurrence average $6.4 \%$ (95\% confidence interval $3.0 \%$ to $11.0 \%$; seven studies, $n=761$ )

Regional recurrence average $2.6 \%(0.04 \%$ to $8.9 \%$; three studies, $n=272)$

Unspecified recurrence average $4.8 \%(0.6 \%$ to $12.8 \%$; six studies, $n=220)$

Death from disease average $9.1 \%(1.4 \%$ to $22.8 \%$; five studies, $n=191)$

\section{Summary: brachytherapy of SCCs}

Four prospective studies and two retrospective studies

Variable methods of application and radiation and generally short follow-up periods

Generally small numbers of patients

Local recurrence average $5.2 \%$ (95\% confidence interval $1.6 \%$ to $10.5 \%$; six studies, $n=88$ )

No regional or distant metastases or deaths attributable to disease reported

\author{
Summary: adjuvant radiotherapy of SCCs \\ Adjuvant radiotherapy for SCCs with perineural invasion (five small retrospective studies) \\ Local recurrence average $18.2 \%$ (95\% confidence interval $3.8 \%$ to $39.8 \%$; five studies, $n=22$ ) \\ Regional recurrence average $8.3 \%(1.1 \%$ to $21.4 \%$; five studies, $n=22)$ \\ Distant metastasis average $11.5 \%(2.4 \%$ to $26.1 \%$, five studies, $n=22)$ \\ Death from disease average $11.1 \%(0.4 \%$ to $33.1 \%$; four studies, $n=20)$ \\ Adjuvant radiotherapy for other SCCs (one prospective and three retrospective small studies) \\ Local recurrence average $11.1 \%(2.4 \%$ to $25.0 \%$; four studies, $n=47)$ \\ Regional recurrence average $8.5 \%(2.5 \%$ to $17.6 \%$; four studies, $n=47)$ \\ Distant metastasis average $3.2 \%(0.1 \%$ to $10.4 \%$; four studies, $n=47)$ \\ Death from disease average $13.9 \%(0.05 \%$ to $50.2 \%$; three studies, $n=21)$
}

work; all authors declare no financial relationships with any organisations that might have an interest in the submitted work in the previous three years; no other relationships or activities that could appear to have influenced the submitted work.

Ethical approval: None required.

Data sharing: Statistical code and dataset are available from the corresponding author at Louise.Lansbury@nottingham.ac.uk.
The lead author (the manuscript's guarantor) affirms that the manuscript is an honest, accurate, and transparent account of the study being reported; that no important aspects of the study have been omitted; and that any discrepancies from the study as planned (and, if relevant, registered) have been explained. 


\section{Summary: curettage and electrodesiccation of SCCs}

Eight retrospective series of variable follow-up periods

Treated SCCs mostly less than $2 \mathrm{~cm}$ diameter

Unspecified recurrence average $1.7 \%$ (95\% confidence interval $0.5 \%$ to $3.4 \%$; seven studies, $n=1131$ )

$20 \%$ recurrence after electrodesiccation and curettage of pinna SCC (one study, $n=20$ )

Lesions more than $2 \mathrm{~cm}$ in size had significantly greater average recurrence than those smaller than $2 \mathrm{~cm}(11.8 \%$ (1.4\% to $36.4 \%, 17$ SCCs) $v 0.4 \%(0 \%$ to $2.1 \%, 264$ SCCs; one study))

\section{Summary: cryotherapy of SCCs}

Six prospective series and three retrospective series with variable follow-up periods

Mostly low risk lesions less than $2 \mathrm{~cm}$ in diameter

Recurrence average $0.8 \%$ (95\% confidence interval $0.1 \%$ to $2.2 \%$; eight studies, $n=273$ )

\section{Summary: photodynamic therapy of SCCs}

Fourteen small prospective case series

Histological confirmation of apparent initial clinical response sought in five of 14 studies

Follow-up for recurrence in eight of 14 studies

Apparent initial complete response average $72.0 \%$ (95\% confidence interval $61.5 \%$ to $81.4 \% ; 14$ studies, $n=297$ )

Recurrence after apparent initial complete response average $26.4 \%$ ( $12.3 \%$ to $43.7 \%$; eight studies, $n=119$ )

\section{What is already known on this topic}

Squamous cell carcinoma (SCC) of the skin is the second most common type of skin cancer, with the potential to recur, metastasise, and lead to death

Surgical excision (by conventional or Mohs micrographic surgery) is currently the preferred treatment for SCC, but no randomised controlled trials have directly compared different treatment modalities for the cancer

\section{What this study adds}

This systematic review compares all treatment types for non-metastatic cutaneous SCC to include evidence from observational studies Accurate comparisons of estimates of treatment effects were not possible from the current evidence, and the significance of apparent differences between treatments should be interpreted cautiously

The current evidence base for SCC treatments is extremely limited, and there is a need for well designed comparative studies to help stratify patients and optimise their clinical management

2 Diffey BL, Langtry JAA. Skin cancer incidence and the ageing population. Br J Dermatol 2005;153:579-80.

3 Hartevelt MM, Bavinck JN, Kootte AM, Vermeer BJ, Vandenbroucke JP. Incidence of skin cancer after renal transplantation in the Netherlands. Transplantation 1990:49:506-9.

4 Jensen P, Hansen S, Moller B, Leivestad T, Pfeffer P, Geiran O, et al. Skin cancer in kidney and heart transplant recipients and different long-term immunosuppressive therapy regimens. J Am Acad Derm 1999;40:177-86.

5 Moloney FJ, Comber H, O'Lorcain P, O'Kelly P, Conlon PJ, Murphy GM. A population-based study of skin cancer incidence and prevalence in renal transplant recipients. Br J Dermatol 2006;154:498-504.

6 Harwood CA, Mesher D, McGregor JM, Mitchell L, Leedham-Green M, Raftery M, et al. A surveillance model for skin cancer in organ transplant recipients: a 22-year prospective study in an ethnically diverse population. Am J Transplant 2013;13:119-29.

7 Edge SB, Byrd DR, Compton CC, Fritz AG, Greene FL, Trotti A, eds. AJCC cancer staging handbook from the AJCC cancer staging manual. 7th ed. Springer 2010.

8 Motley R, Kersey P, Lawrence C. Multiprofessional guidelines for the management of the patient with primary cutaneous squamous cell carcinoma. Br J Dermatol 2002;146:18-25.

Lansbury L, Leonardi-Bee J, Perkins W, Goodacre T, Tweed JA, Bath-Hextall FJ. Interventions for non-metastatic squamous cell carcinoma of the skin. Cochrane Database Syst Rev 2010;4:CD007869.

10 Stroup DF, Berlin JA, Morton SC, Olkin I, Williamson GD, Rennie D, et al. Meta-analysis of observational studies in epidemiology: a proposal for reporting. Meta-analysis $\mathrm{O}$ Observational Studies in Epidemiology (MOOSE) group. JAMA 2000;283:2008-12.

11 Scottish Intercollegiate Guidelines Network. Observational studies search filter internet. 2013. www.sign.ac.uk/methodology/filters.html\#obs.

12 Williams H, Bigby M, Diepgen T, Herxheimer A, Naldi L, Rzany B, eds. Evidence-based dermatology. 2nd ed. Blackwell Publishing, 2008.

13 Stuart A, Ord JK. Kendall's advanced theory of statistics. 6th ed. Edward Arnold, 1994

14 Baker NJ, Webb AAC, Macpherson D. Surgical management of cutaneous squamous cell carcinoma of the head and neck. Br J Oral Maxillofac Surg 2001;39:87-90.

15 Rank B. Surgery and skin cancer. Ann R Coll Surg Engl 1973;52:148-64.

16 Donaldson MJ, Sullivan TJ, Whitehead KJ, Williamson RM. Squamous cell carcinoma of the eyelids. Br J Ophthalmol 2002;86:1161-5.

17 Griffiths RW, Feeley K, Suvarna SK. Audit of clinical and histological prognostic factors in primary invasive squamous cell carcinoma of the skin: assessment in a minimum 5 year follow-up study after conventional excisional surgery. Br J Plast Surg 2002;55:287-92.
18 van der Eerden PA, Prins EF, Lohuis PJFM, Balm AJ, Vuyk H. Eighteen years of experience in Mohs micrographic surgery and conventional excision for nonmelanoma skin cancer treated by a single facial plastic surgeon and pathologist. Laryngoscope 2010;120:2378-84.

19 Nemet AY, Deckel Y, Martin PA, Kourt G, Chilov M, Sharma V, et al. Management of periocular basal and squamous cell carcinoma: a series of 485 cases. Am J Ophthalmol 2006;142:293-7

20 Shiffman NJ. Squamous cell carcinomas of the skin of the pinna. Can J Surg 1975;18:279-83

21 Reifler DM, Hornblass A. Surgical management of squamous cell carcinoma of the lid. Ophthal Plast Reconstr Surg 1986;2:75-82.

22 Shiu MH, Chu F, Fortner JG. Treatment of regionally advanced epidermoid carcinoma of the extremity and trunk. Surg Gynecol Obstet 1980;150:558-62.

23 Thomas SS, Matthews RN. Squamous cell carcinoma of the pinna: a 6-year study. Br J Plast Surg 1994;47:81-5.

24 Pless J. Carcinoma of the external ear. Scand J Plast Reconstr Surg 1976:10:147-51.

25 Fitzpatrick P, Harwood AA. Acute epithelioma-an aggressive squamous cell carcinoma of the skin. Am J Clin Oncol 1985;8:468-71.

26 Mourouzis C, Boynton A, Grant J, Umar T, Wilson A, Macpheson D, et al. Cutaneous head and neck SCCs and risk of nodal metastasis. J Craniomaxillofac Surg 2009;37:443-7.

27 Knox JM, Freeman RG, Duncan WC, Heaton CL. Treatment of skin cancer. South Med $J$ 1967;60:241-6

28 Ang P, Tan AWH, Goh CL. Comparison of completely versus incompletely excised cutaneous squamous cell carcinoma. Ann Acad Med Singapore 2004;33:68-70.

29 Friedman HI, Cooper PH, Wanebo HJ. Prognostic and therapeutic use of microstaging of cutaneous squamous cell carcinoma of the trunk and extremities. Cancer 1984;56:1105-985.

30 Werlinger KD, Upton G, Moore AY. Recurrence rates of primary nonmelanoma skin cancers treated by surgical excision compared to electrodesiccation-curettage in a private dermatological practice. Dermatol Surg 2002;28:1138-42.

31 Yoon M, Chougule P, Dufresne R, Wanebo HJ. Localized carcinoma of the external ear is an unrecognized aggressive disease with a high propensity for local regional recurrence. Am J Surg 1992;164:574-7.

32 Pua VSC, Huilgol S, Hill D. Evaluation of the treatment of non-melanoma skin cancers by surgical excision. Australas J Dermatol 2009;50:171-5.

33 Thomas DJ, King AR, Peat BG. Excision margins for nonmelanotic skin cancer. Plast Reconstr Surg 2003;112:57-63. 
34 Tan PY. Incomplete excision of squamous cell carcinoma of the skin: a prospective observational study. Plast Reconstr Surg 2007:120:910-6.

35 Bogdanov-Berezovsky A, Cohen AD, Glesinger R, Cagnano E, Rosenberg L. Risk factors for incomplete excision of squamous cell carcinomas. J Dermatolog Treat 2005;16:341-4

36 Bovill ES, Cullen KW, Barrett W, Banwell PE. Clinical and histological findings in re-excision of incompletely excised cutaneous squamous cell carcinoma. J Plast Reconstr Aesthet Surg 2009;62:457-61.

37 Mohs FE. Chemosurgery: microscopically controlled surgery for skin cancer. Charles C Thomas, 1978.

38 Mohs FE, Larson PO, Iriondo M. Micrographic surgery for the microscopically controlled excision of carcinoma of the external ear. J Am Acad Dermatol 1988;19:729-37.

39 Mohs FE. Micrographic surgery for the microscopically controlled excision of eyelid cancers. Arch Ophthalmol 1986;104:901-9.

40 Anderson RL. Results in eyelid malignancies treated with the Mohs fresh tissue technique. Trans New Orleans Acad Ophthalmol 1982;30:380-91.

41 Pugliano-Mauro M, Goldman G. Mohs surgery is effective for high-risk cutaneous squamous cell carcinoma. Dermatol Surg 2010;36:1544-53.

42 Vuyk HD, Lohuis PJFM. Mohs micrographic surgery for facial skin cancer. Clin Otolaryngol 2001;26:265-73.

43 Turner RJ, Leonard N, Malcolm AJ, Lawrence CM, Dahl MG. A retrospective study of outcome of Mohs' micrographic surgery for cutaneous squamous cell carcinoma using formalin fixed sections. Br J Dermatol 2000;142:752-7.

44 Leibovitch I, Huilgol SC, Selva D, Hill D, Richards S, Paver R. Cutaneous squamous cell carcinoma treated with Mohs micrographic surgery in Australia I. Experience over 10 years. J Am Acad Dermatol 2005;53:253-60.

45 Brantsch KD, Meisner C, Schonfisch B, Trilling B, Wehner-Caroli J, Rocken M, et al. Analysis of risk factors determining prognosis of cutaneous squamous-cell carcinoma: a prospective study. Lancet Oncol 2008;9:713-20.

46 Dzubow LM, Rigel DS, Robins P. Risk factors for local recurrence of primary cutaneous squamous cell carcinomas. Treatment by microscopically controlled excision. Arch Dermatol 1982;118:900-2.

47 Silapunt S, Peterson SR, Goldberg LH. Squamous cell carcinoma of the auricle and Mohs micrographic surgery. Dermatol Surg 2005;31:1423-7.

48 Malhotra R, Huilgol SC, Huynh NT, Selva D. The Australian Mohs database: periocular squamous cell carcinoma. Ophthalmology 2004;111:617-23.

49 Cherpelis BS, Marcusen C, Lang PG. Prognostic factors for metastasis in squamous cell carcinoma of the skin. Dermatol Surg 2002;28:268-73.

50 Tomsick RS, Menn H. Squamous cell carcinoma of the fingers treated with chemosurgery. South Med J 1984:77:1124-6.

51 Mohs FE. Chemosurgery for skin cancer. Arch Dermatol 1976;112:211-5.

52 Skaria AM. Recurrence of basosquamous carcinoma after Mohs Micrographic Surgery. Dermatology 2010;221:352-5

53 Thomas CJ, Wood GC, Marks VJ. Mohs micrographic surgery in the treatment of rare aggressive cutaneous tumors: the Geisinger experience. Dermatol Surg 2007;33:333-9.

54 Stoll HL Jr, Milgrom H, Traenkle HL. Results of roebtgen therapy of carcinoma of the nose. Arch Dermatol 1964;90:577-80.

55 Abbatucci JS, Boulier N, Laforge T, Lozier JC. Radiation therapy of skin carcinomas: results of a hypofractionated irradiation schedule in 675 cases followed more than 2 years. Radiother Oncol 1989;14:113-9.

56 Grosch E, Lambert HE. The treatment of difficult cutaneous basal and squamous cell carcinomata with electrons. Br J Radiol 1979;52:472-7.

57 Podd TJ. Treatment of lower limb basal cell and squamous cell carcinomas with radiotherapy. Clin Oncol (R Coll Radiol) 1992;4:44-5.

58 Tsao MN, Tsang RW, Liu F-F, Panzarella T, Rotstein L. Radiotherapy management for squamous cell carcinoma of the nasal skin: the Princess Margaret Hospital experience. Int J Radiat Oncol Biol Phys 2002;52:973-9.

59 Kwan W, Wilson D, Moravan V. Radiotherapy for locally advanced basal cell and squamous cell carcinomas of the skin. Int J Radiat Oncol Biol Phys 2004;60:406-11.

60 Honeycutt WM, Jansen GT. Treatment of squamous cell carcinoma of the skin. Arch Dermatol 1973;108:670-2.

61 Holmes ME, Bomford CK, Phil M. The use of a short distance cobalt unit in the treatment of primary skin tumors. Br J Radiol 1982;55:225-8.

62 Hunter RD, Pereira DT, Pointon RC. Megavoltage electron beam therapy in the treatment of basal and squamous cell carcinomata of the pinna. Clin Radiol 1982;3;33:341-5.

63 Matthiesen C, Thompson JS, Forest C, Ahmad S, Herman T, Bogardus C Jr. The role of radiotherapy for T4 non-melanoma skin carcinoma. J Med Imaging Radiat Oncol 2011;55:407-16.

64 Barysch MJ, Eggman N, Beyeler M, Panizzon RG, Seifert B, Dummer R. Long-term recurrence rate of large and difficult to treat cutaneous squamous cell carcinomas after superficial radiothrapy. Dermatology 2012;224:59-65.

65 Allan E, Stanton A, Pye D, Collins C, Perry L, Filby M, et al. Fractionated high dose rate brachytherapy moulds-a precise treatment for carcinoma of the pinna. Radiother Onco 1998;48:277-81.

66 Rio E, Bardet E, Ferron C, Peuvrel P, Supiot S, Campion L, et al. Interstitial brachytherapy of periorificial skin carcinomas of the face: a retrospective study of 97 cases. Int $J$ Radiat Oncol Biol Phys 2005:63:753-7.

67 Lee JD, Park KK, Lee M-G, Kim E-H, Rhim KJ, Lee JT, et al. Radionuclide therapy of skin cancers and Bowen's disease using a specially designed skin patch. $J$ NuCl Med 1997;38:697-702.

68 Svoboda VH, Kovarik J, Morris F. High dose-rate microselectron molds in the treatment of skin tumors. Int J Radiat Oncol Biol Phys 1995;31:967-72.

69 Ashby MA, Pacella JA, de Groot R, Ainslie J. Use of a radon mould technique for skin cancer: results from the Peter MacCallum Institute (1975-1984). Br J Radiol 1989;62:608-12.

70 Guix B, Finestres F, Tello J, Palma C, Martinez A, Guix J, et al. Treatment of skin carcinomas of the face by high-dose-rate brachytherapy and custom-made surface molds. Int J Radiat Oncol Biol Phys 2000;47:95-102.

71 Barrett TL, Greenway HT, Massullo V, Carlson C. Treatment of basal cell carcinoma and squamous cell carcinoma with perineural invasion. Adv Dermatol 1993;8:277-305.

72 Cottel WI. Perineural invasion by squamous-cell carcinoma. J Dermatol Surg Onco 1982;8:589-600

73 DeAmbrosis K, De'Ambrosis B. Nonmelanoma skin cancer with perineural invasion: report of outcomes of a case series. Dermatol Surg 2010;36:133-8.
74 Geist DE, Garcia-Moliner M, Fitzek MM, Cho H, Rogers GS. Perineural invasion of cutaneous squamous cell carcinoma and basal cell carcinoma: raising awareness and optimizing management. Dermatol Surg 2008;34:1642-51.

75 Osguthorpe JD, Abel EA, Lang PG, Hochman M. Neurotropic cutaneous tumors of the head and neck. Arch Otolaryngol Head Neck Surg 1997;123:871-6.

76 Khan NA, Akhtar S, Kharadi MY, Andrabi WH, Darzi MA. Role of elective irradiation to drainage sites in squamous cell carcinoma of the skin trunk and extremities. JK Practitioner 1999;6:35-8.

77 Lifeso RM, Rooney RJ, El-Shaker M. Post-traumatic squamous-cell carcinoma. J Bone Joint Surg Am 1990;72:12-8.

78 Veness MJ, Quinn DI, Ong CS, Keogh AM, Macdonald PS, Cooper SG, et al. Aggressive cutaneous malignancies following cardiothoracic transplantation. The Australian experience. Cancer 1999;85:1758-64.

79 Reschly MJ, Shenefelt PD. Controversies in skin surgery: electrodesiccation and curettage cersus excision for low-risk, small, well-differentiated squamous cell carcinomas. J Drugs Dermatol 2010;9:773-6.

80 Tromovitch TA. Skin cancer. Treatment by curettage and desiccation. Calif Med 1965;103:107-8.

81 Whiting DA. Skin tumours in white South Africans. Part V. Treatment of skin tumours. S Afr Med J 1978;53:166-70.

82 Williamson GS, Jackson R. Treatment of squamous cell carcinoma of the skin by electrodesiccation and curettage. CMAJ 1964;90:408-13

83 Kuflik EG. Cryosurgery for skin cancer: 30-year experience and cure rates. Dermatol Surg 2004;30:297-300.

84 Fraunfelder FT, Zacarian SA, Limmer BL, Wingfield D. Cryosurgery for malignancies of the eyelid. Ophthalmology 1980;87:461-5.

85 Kuflik EG. Cryosurgical treatment for large malignancies on the upper extremities. $J$ Dermatol Surg Oncol 1986;12:575-7.

86 Fontana AM, Muti E. Results with cryotherapy in skin tumours. Panminerva Med 1975;17:384-9.

87 Nordin P, Stenquist B. Five-year results of curettage-cryosurgery for 100 consecutive auricular non-melanoma skin cancers. J Laryngol Otol 2002;116:893-8.

88 Peikert JM. Prospective trial of curettage and cryosurgery in the management of non-facial, supericial, and minimally invasive basal and squamous cell carcinoma. Int $J$ Dermatol 2011;50:1135-8.

89 Lindemalm-Lundstam B, Dlenback J. Prospective follow-up after curettage-cryosurgery for scalp and face skin cancers. Br J Dermatol 2009;161:568-76.

90 Holt PJA. Cryotherapy for skin cancer: results over a 5 year period using liquid nitrogen spray therapy. Br J Dermatol 1988;119:231-40.

91 Graham GF, Clark LC. Statistical analysis in cryosurgery of skin cancer. Clin Dermatol 1990;8:101-7.

92 Kennedy JC, Pottier RH, Pross DC. Photodynamic therapy with endogenous protoporphyrin IX: basic principles and present clinical experience. J Photochem Photobiol B 1990;6:143-8.

93 Lui H, Salasche S, Kollias N, Wimberly J, Flotte T, McLean D, et al. Photodynamic therapy of nonmelanoma skin cancer with topical aminolevulinic acid: a clinical and histologic study. Arch Dermatol 1995;131:737-8.

94 Baptista J, Martinez C, Leite L, Cochito M. Our PDT experience in the treatment of non-melanoma skin cancer over the last 7 years. $J$ Eur Acad Dermatol Venereol 2006;20:693-7.

95 Calzavara-Pinton PG. Repetitive photodynamic therapy with topical delta-aminolaevulinic acid as an appropriate approach to the routine treatment of superficial non-melanoma skin tumours. J Photochem Photobiol B 1995;29:53-7.

96 Fink-Puches R, Soyer HP, Hofer A, Kerl H, Wolf P. Long-term follow-up and histological changes of superficial nonmelanoma skin cancers treated with topical delta-aminolevulinic acid photodynamic therapy. Arch Dermatol 1998;134:821-6.

97 Ziolkowski P, Osiecka BJ, Oremek G, Siewinski M, Symonowicz K, Saleh Y, et al. Enhancement of photodynamic therapy by use of aminolevulinic acid/glycolic acid drug mixture. J Exp Ther Oncol 2004;4:121-9.

98 Calzavara-Pinton PG, Venturini M, Sala R, Capezzera R, Parrinello G, Specchia C, et al. Methylaminolaevulinate-based photodynamic therapy of Bowen's disease and squamous cell carcinoma. Br J Dermatol 2008;159:137-44.

99 Haddad R, Nesher E, Weiss J, Skornick Y, Kashtan H. Photodynamic therapy for Bowen's disease and squamous cell carcinoma of the skin. Photodiagnosis Photodyn Ther 2004;1:225-30.

100 Fritsch C, Goerz G, Ruzicka T. Photodynamic therapy in dermatology. Arch Dermatol 1998; 134:2007-214.

101 Harth Y, Hirshowitz B, Kaplan B. Modified topical photodynamic therapy of superficial skin tumors, utilizing aminolevulinic acid, penetration enhancers, red light, and hyperthermia. Dermatol Surg 1998:24:723-6.

102 Pennington RG, Waner M, Knox A. Photodynamic therapy for multiple skin cancers. Plast Reconstr Surg 1988;82:1067-1071.

103 Wolf $\mathrm{P}$, Rieger E, Kerl H. Topical photodynamic therapy with endogenous porphyrins afte application of 5-aminolevulinic acid. An alternative treatment modality for solar keratoses, superficial squamous cell carcinomas, and basal cell carcinomas? [Published rrratum appears in J Am Acad Dermatol 1993;29:41.] J Am Acad Dermatol 1993;28:17-21.

104 Feyh J, Goetz A, Muller W, Konigsberger R, Kastenbauer E. Photodynamic therapy in head and neck surgery. J Photochem Photobiol B 1990;7:353-8.

105 Kubler AC, Haase T, Staff C, Kahle B, Rheinwald M, Muhling J. Photodynamic therapy of primary nonmelanomatous skin tumours of the head and neck. Lasers Surg Med 1999;25:60-8.

106 Chren MM, Linos E, Torres JS, Stuart SE, Parvataneni R, Boscardin J. Tumor recurrence 5 years after treatment of cutaneous basal cell carcinoma and squamous cell carcinoma. $J$ Invest Dermatol 2013;133:1188-96.

107 Jambusaria-Pahlajani A, Miller CJ, Quon H, Smith N, Klein RQ, Schmults CD, et al. Surgical monotherapy versus surgery plus adjuvant radiotherapy in high-risk cutaneous squamous cell carcinoma: a systematic review of outcomes. Dermatol Surg 2009;35:574-85

108 Gibbons E, Casanas ICC, Fitzpatrick R. A structured review of patient-reported outcome measures for patients with skin cancer, 2013. Br J Dermatol 2013;168:1176-86.

109 Bates AS, Davis CR, Takwale A, Knepil GJ. Patient-reported outcome measures in nonmelanoma skin cancer of the face: a systematic review. $\mathrm{Br} J$ Dermatol 2013;168:1187-94

110 Zwald FO, Brown M. Skin cancer in solid organ transplant recipients: advances in therap and management: part II. Management of skin cancer in solid organ transplant recipients. J Am Acad Dermatol 2011;65:263-79. 
111 Dinehart SM, Pollack SV. Metastases from squamous cell carcinoma of the skin and lip. An analysis of twenty-seven cases. J Am Acad Dermatol 1989;21:241-8.

112 Rowe DE, Carroll RJ, Day CL Jr. Prognostic factors for local recurrence, metastasis, and survival rates in squamous cell carcinoma of the skin, ear, and lip. Implications for treatment modality selection. J Am Acad Derm 1992;26:976-90.

113 Brougham NDLS, Dennett ER, Cameron R, Tan ST. The incidence of metastasis from cutaneous squamous cell carcinoma and the impact of its risk factors. J Surg Oncol 2012:106:811-5

114 Higgins JPT, Green S, eds. Cochrane Handbook of systematic reviews of interventions. Version 5.1.0. 2011. www.cochrane-handbook.org/.

115 Moses LE. The series of consecutive cases as a device for assessing outcomes of intervention. N Engl J Med 1984;311:705-10.

116 Abel U. Erkenntnisgewinn mittels nichtrandomisierter therapiestudien — gaining understanding through nonrandomized therapeutic studies. Ellipse 1999;15:48-58.

117 Jenicek M, ed. Clinical case reporting in evidence-based medicine. 2nd ed. Arnold, 2001.

118 Albrecht J, Meves A, Bigby M. A survey of case reports and case series of therapeutic interventions in the Archives of Dermatology. Int J Dermatol 2009;48:592-7.

119 Edge SB, Byrd DR, Compton CC, Fritz AG, Greene FL, Trotti A, eds. AJCC cancer staging manual. 7th ed. NYL Springer, 2010.
120 Breuninger H, Brantsch K, Eigentler T, Hafner HM. [Comparison and evaluation of the current staging of cutaneous carcinomas] [German]. J Dtsch Dermatol Ges 2012:10:579-86. 121 Jambusaria-Pahlajani A, Kanetsky PA, Karia PS, Hwang WT, Gelfand JM, Whalen FM, et al. Evaluation of AJCC tumor staging for cutaneous squamous cell carcinoma and a proposed alternative tumor staging system. JAMA Dermatol 2013;149:402-10.

122 Buethe D, Warner C, Miedler J, Cockerell CJ. Focus issue on squamous cell carcinoma: practical concerns regarding the 7th edition AJCC staging guidelines. J Skin Cancer 2011, doi:10.1155/2011/156391.

Accepted: 11 September 2013

\section{Cite this as: BMJ 2013;347:f6153}

This is an Open Access article distributed in accordance with the Creative Commons Attribution Non Commercial (CC BY-NC 3.0) license, which permits others to distribute, remix, adapt, build upon this work non-commercially, and license their derivative works on different terms, provided the original work is properly cited and the use is non-commercial. See: http://creativecommons.org/licenses/by-nc/3.0/. 


\section{Tables}

\section{Table 1| Recurrence and death after surgical excision}

\begin{tabular}{|c|c|c|c|c|c|c|c|c|}
\hline \multirow{2}{*}{$\begin{array}{l}\text { Study and No of } \\
\text { patients }\end{array}$} & \multirow[t]{2}{*}{ Site } & \multirow[t]{2}{*}{ Follow-up } & \multicolumn{5}{|c|}{ Proportion with outcome (95\% Cl) } & \multirow[t]{2}{*}{ Prognostic features* } \\
\hline & & & $\begin{array}{l}\text { Local } \\
\text { recurrence }\end{array}$ & $\begin{array}{l}\text { Regional } \\
\text { recurrence }\end{array}$ & $\begin{array}{c}\text { Distant } \\
\text { metastases }\end{array}$ & $\begin{array}{l}\text { Unspecified } \\
\text { recurrence }\end{array}$ & $\begin{array}{l}\text { Patient died } \\
\text { of disease }\end{array}$ & \\
\hline Ang $2004(n=50)$ & Various & $\begin{array}{c}\text { Mean } 71.1 \\
\text { months (range } \\
28-109 \text { ) }\end{array}$ & - & - & - & $\begin{array}{c}0.00(0.00 \text { to } \\
0.07)\end{array}$ & - & $\begin{array}{l}\text { Mean diameter } 19.7 \mathrm{~mm} \text { (range } \\
4-60)\end{array}$ \\
\hline
\end{tabular}

\begin{tabular}{llllll}
\hline Baker $2001 \quad H e a d$ and 2 years minimum & $0.04(0.02$ to & $0.03(0.01$ to $\quad-\quad ~$ & - & $0.00(0.00$ to
\end{tabular}

\begin{tabular}{lcccc}
$(\mathrm{n}=227)$ & neck & $0.07)$ & $0.06)$ & -103 \\
\hline
\end{tabular}

Donaldson $2002 \quad$ Eyelids $\quad 31.1$ months $\quad 0.00(0.00$ to $\quad 0.00(0.00$ to $0.00(0.00$ to $\quad-\quad 0.00(0.00$ to Perineural invasion (8\%), orbital

\begin{tabular}{|c|c|c|c|c|c|}
\hline $\begin{array}{l}\text { Donaldson } 2002 \\
(n=35)\end{array}$ & Eyelids & 31.1 months & $\begin{array}{c}0.00(0.00 \text { to } \\
0.10)\end{array}$ & $\begin{array}{c}0.00(0.00 \mathrm{tc} \\
0.1)\end{array}$ & $\begin{array}{c}0.00(0.00 \text { to } \\
0.1)\end{array}$ \\
\hline
\end{tabular}

\begin{tabular}{lllcllll}
\hline Fitzpatrick 1985 & Eyelids & Not specified & $0.05(0.00$ to & - & - & - & -
\end{tabular}

\begin{tabular}{lllll}
$(\mathrm{n}=21)$ & $0.24)$ & $(38 \%) ;$ median duration $52 \mathrm{meek}$ \\
\hline Friedman 1984 & Trunk and Non-recurrent & $0.14(0.07 \mathrm{to}$ & $0.08(0.03$ to & Depth $\leq 4 \mathrm{~mm}(62 \%), 4-8 \mathrm{~mm}$
\end{tabular}

\begin{tabular}{|c|c|c|}
\hline $\begin{array}{l}\text { Friedman } 1984 \\
(n=63)\end{array}$ & $\begin{array}{l}\text { Trunk and } \\
\text { extremities }\end{array}$ & $\begin{array}{c}\text { Non-recurrent } \\
\text { group: mean } 7.5\end{array}$ \\
\hline
\end{tabular}

years; recurrent $\quad$ differentiation grades I $(30 \%), \mathrm{II}$

group: minimum $\quad(60 \%)$, III $(10 \%)$

\begin{tabular}{lllllll}
\hline Griffiths 2002 & All & Minimum 5 years & $0.00(0.00$ to & - & -
\end{tabular}$\quad$ - $\quad 0.08$ (0.03 to Median thickness 3.1 mm; mean

$\begin{array}{lccc}(n=86) & - & -0.04) & 0.16)\end{array}$

patients) $v 20 \mathrm{~mm}$ (patients who died of disease),

immunocompromised $(3.2 \%)$

\begin{tabular}{lllllllll}
\hline Knox 1967 & Various & $>1$ year & - & - & $0.00(0.00$ to & - & - & Diameter $<2 \mathrm{~cm}(80 \%),>2 \mathrm{~cm}$
\end{tabular}

\begin{tabular}{llllllll}
\hline Mourouzis 2009 & Head and & $30-60$ months & - & $0.05(0.02$ to & - & - & $-\quad$
\end{tabular}$\quad \begin{gathered}\text { Diameter }<2 \mathrm{~cm}(63 \%), 2-4 \mathrm{~cm} \\
(\mathrm{n}=194)\end{gathered}$

$\begin{array}{llll}(n=194) & \text { neck } & 0.09) & (33.8 \%),>4 \mathrm{~cm}(3.2 \%) ; \text { histolog } \\ \text { grade: well/moderately }\end{array}$

differentiated $(78.2 \%)$, poorly

differentiated $(21.8 \%)$; perineural

invasion $(2.3 \%)$; perivascular invasion $(0.5 \%)$

\begin{tabular}{|c|c|c|c|c|c|c|c|c|}
\hline $\begin{array}{l}\text { Nemet } 2006 \\
(n=68)\end{array}$ & Periocular & Mean 33 months & $\begin{array}{l}0.06(0.02 \text { to } \\
0.14)\end{array}$ & - & - & - & - & $\begin{array}{c}\text { Differentiation: well }(86.8 \%) \\
\text { moderate }(13.2 \%)\end{array}$ \\
\hline $\begin{array}{l}\text { Pless } 1976 \\
(n=176)\end{array}$ & External ear & Not specified & $\begin{array}{l}0.15(0.10 \text { to } \\
0.22)\end{array}$ & $\begin{array}{l}0.06(0.03 \text { to } \\
0.11)\end{array}$ & - & - & - & Diameter $<10 \mathrm{~mm}$ to $>40 \mathrm{~mm}$ \\
\hline $\begin{array}{l}\text { Rank } 1973 \\
(\mathrm{n}=288)\end{array}$ & All & 2 years & $\begin{array}{l}0.01(0.00 \text { to } \\
0.04)\end{array}$ & - & - & - & - & Not specified \\
\hline $\begin{array}{l}\text { Reifler } 1986 \\
(n=12)\end{array}$ & Eyelid & Mean 3 years & $\begin{array}{l}0.08(0.00 \text { to } \\
0.38)\end{array}$ & $\begin{array}{l}0.00(0.00 \text { to } \\
0.26)\end{array}$ & - & - & $\begin{array}{l}0.00(0.26 \text { to } \\
2.64)\end{array}$ & $\begin{array}{c}\text { Surface area }<1 \mathrm{~cm}(58 \%) ;>1 \mathrm{~cm} \\
(42 \%)\end{array}$ \\
\hline $\begin{array}{l}\text { Shiffman } 1975 \\
(n=31)\end{array}$ & Pinna & $\begin{array}{c}<1 \text { year to }>3 \\
\text { years }\end{array}$ & $\begin{array}{c}0.06(0.01 \text { to } \\
0.21)\end{array}$ & $\begin{array}{c}0.10(0.02 \text { to } \\
0.26)\end{array}$ & - & - & $\begin{array}{c}0.03(0.00 \text { to } \\
0.17)\end{array}$ & $\begin{array}{c}\text { Diameter }<2 \mathrm{~cm}(59.6 \%), 2-4 \mathrm{~cm} \\
(28.8 \%),>4 \mathrm{~cm}(3.8 \%) ; \text { invasion of } \\
\text { cartilage }(21.1 \%)\end{array}$ \\
\hline Shiu $1980(n=38)$ & $\begin{array}{l}\text { Trunk and } \\
\text { extremities }\end{array}$ & Not specified & $\begin{array}{c}0.10(0.03 \text { to } \\
0.25)\end{array}$ & - & - & - & $\begin{array}{c}0.06(0.01 \text { to } \\
0.18)\end{array}$ & $\begin{array}{l}10.5 \% \text { of stage I SCCs were high } \\
\text { grade; included tumours secondary } \\
\text { to radiation exposure, chronic } \\
\text { dermatitis in ulcers, and } \\
\text { osteomyelitis }\end{array}$ \\
\hline
\end{tabular}

\begin{tabular}{|c|c|c|c|c|c|c|c|c|}
\hline $\begin{array}{l}\text { Thomas } 1994 \\
(n=54)\end{array}$ & Pinna & $\begin{array}{c}<1 \text { year to }>3 \\
\text { years }\end{array}$ & $\begin{array}{c}0.13(0.05 \text { to } \\
0.25)\end{array}$ & $\begin{array}{c}0.09(0.03 \text { to } \\
0.20)\end{array}$ & - & - & $\begin{array}{c}0.04(0.00 \text { to } \\
0.15)\end{array}$ & $\begin{array}{l}\text { Stages I }(52 \%) \text {, II }(37 \%) \text {, III }(0 \%) \text {, } \\
\text { IV ( } 11 \%) \text {; differentiation: well } \\
(68.5 \%) \text {, moderate }(9.3 \%) \text {, poor }\end{array}$ \\
\hline
\end{tabular}

\begin{tabular}{|c|c|c|c|c|c|c|c|c|}
\hline $\begin{array}{l}\text { Van der Eerden } \\
2010(n=108)\end{array}$ & $\begin{array}{c}\text { Head and } \\
\text { neck }\end{array}$ & Mean 16 months & $\begin{array}{c}0.02(0.00 \text { to } \\
0.06)\end{array}$ & $\begin{array}{c}0.01 \text { ( } 0.00 \text { to } \\
0.05)\end{array}$ & - & - & - & No data \\
\hline $\begin{array}{l}\text { Werlinger } 2002 \\
(n=20)\end{array}$ & Various & Mean 4.1 years & - & - & - & $\begin{array}{c}0.00(0.00 \text { to } \\
0.17)\end{array}$ & - & $\begin{array}{c}\text { Diameter mean } 7.9 \mathrm{~mm} \text { (SD 3.7), } \\
<5 \mathrm{~mm}(14.1 \%), 5-10 \mathrm{~mm}(69.4 \%) \\
>10 \mathrm{~mm}(16.4 \%) ; 5.2 \% \text { of all } \\
\text { tumours displayed aggressive } \\
\text { growth pattern }\end{array}$ \\
\hline
\end{tabular}




\section{Table 1 (continued)}

\begin{tabular}{|c|c|c|c|c|c|c|c|c|}
\hline \multirow{2}{*}{$\begin{array}{l}\text { Study and No of } \\
\text { patients }\end{array}$} & \multirow[t]{2}{*}{ Site } & \multirow[t]{2}{*}{ Follow-up } & \multicolumn{5}{|c|}{ Proportion with outcome $(95 \% \mathrm{Cl})$} & \multirow[t]{2}{*}{ Prognostic features* } \\
\hline & & & $\begin{array}{l}\text { Local } \\
\text { recurrence }\end{array}$ & $\begin{array}{l}\text { Regional } \\
\text { recurrence }\end{array}$ & $\begin{array}{c}\text { Distant } \\
\text { metastases }\end{array}$ & $\begin{array}{l}\text { Unspecified } \\
\text { recurrence }\end{array}$ & $\begin{array}{l}\text { Patient died } \\
\text { of disease }\end{array}$ & \\
\hline Yoon $1992(n=13)$ & External ear & $\begin{array}{c}6 \text { months to } 20 \\
\text { years }\end{array}$ & - & - & - & $\begin{array}{c}0.62(0.32 \text { to } \\
0.86)\end{array}$ & - & $\begin{array}{c}\text { Stages } 0(5 \%), \text { I }(37.5 \%) \text {, II } \\
(32.5 \%) \text {, III (5\%), IV (10\%); } \\
\text { unknown (10\%) }\end{array}$ \\
\hline
\end{tabular}

$\mathrm{SD}=$ standard deviation

*Percentages indicate proportion of patients in study. 


\begin{tabular}{|c|c|c|c|c|}
\hline $\begin{array}{l}\text { Study and No of } \\
\text { excisions }\end{array}$ & Site & $\begin{array}{l}\text { Proportion }(95 \% \mathrm{Cl}) \\
\text { incompletely excised }\end{array}$ & Prognostic features* & Excision margin \\
\hline Ang $2004(n=63)$ & All & $0.16(0.08$ to 027$)$ & Mean diameter $19.7 \mathrm{~mm}$ & Retrospective; 4-6 mm margin \\
\hline Baker $2001(n=227)$ & $\begin{array}{l}\text { Head and } \\
\text { neck }\end{array}$ & $0.07(0.04$ to 0.11$)$ & No data & Retrospective; margin not specified \\
\hline $\begin{array}{l}\text { Bogdanov-Berezovsky } \\
2005(n=369)\end{array}$ & All & 0.07 (0.04 to 0.10$)$ & $\begin{array}{c}\text { Completely excised: diameter } 1.1 \mathrm{~cm} \text {, depth } 0.6 \mathrm{~cm} \text {; } \\
\text { differentiation: well }(84.6 \%) \text {, moderate }(13.6 \%) \text {, poor } \\
(5.6 \%) . \text { Incompletely excised: diameter } 0.9 \mathrm{~cm} \text {, depth } \\
0.4 \mathrm{~cm} \text {; differentiation: well }(72.2 \%) \text {; moderate } \\
(22.2 \%) \text {; poor }(5.6 \%)\end{array}$ & Retrospective; 3-6 mm margin \\
\hline Bovill $2009(n=676)$ & All & $0.18(0.15$ to 0.21$)$ & $\begin{array}{c}\text { Re-excision cohort: mean diameter } 17.2 \mathrm{~mm} \text {, mean } \\
\text { thickness } 6.02 \mathrm{~mm} \text {; differentiation: well }(43 \%) \text {, } \\
\text { moderate }(42 \%) \text {; poor }(15 \%) \text {, perineural invasion } \\
(3.6 \%)\end{array}$ & Retrospective; margin not specified \\
\hline Griffiths $2002(n=93)$ & All & $0.04(0.01$ to 0.11$)$ & $\begin{array}{l}\text { Median thickness } 3.1 \mathrm{~mm} \text {; mean diameter } 13 \mathrm{~mm} \\
\text { (surviving patients) } v 20 \mathrm{~mm} \text { (patients who died of } \\
\text { disease); immunocompromised (3.2\%) }\end{array}$ & $\begin{array}{l}\text { Retrospective; mean margin } 7.2 \mathrm{~mm} \\
\text { (surviving patients) } v 6.3 \mathrm{~mm} \\
\text { (patients who died of disease) }\end{array}$ \\
\hline Mourouzis $2009(\mathrm{n}=218)$ & $\begin{array}{l}\text { Head and } \\
\text { neck }\end{array}$ & $0.12(0.08$ to 0.17$)$ & $\begin{array}{c}\text { Diameter }<2 \mathrm{~cm}(63 \%), 2-4 \mathrm{~cm}(33.8 \%),>4 \mathrm{~cm} \\
(3.2 \%) \text {; differentiation: well }(78.2 \%), \text { poor }(21.8 \%) \text {; } \\
\text { perineural invasion }(2.3 \%) \text {, perivascular invasion } \\
(0.5 \%)\end{array}$ & Retrospective; $5 \mathrm{~mm}$ margin \\
\hline Nemet $2006(n=68)$ & Periocular & $0.25(0.15$ to 0.37$)$ & Differentiation: well (86.8\%), moderate (13.2\%) & Retrospective; $5 \mathrm{~mm}$ margin \\
\hline Pua $2009(n=69)$ & All & $0.00(0.00$ to 0.05$)$ & Diameter $<1 \mathrm{~cm}$ to $2 \mathrm{~cm}$ & $\begin{array}{l}\text { Retrospective; } 4 \text { mm ("wider" for } \\
\text { larger tumours) }\end{array}$ \\
\hline Tan $2007(n=480)$ & All & $0.06(0.04$ to 0.09$)$ & $\begin{array}{c}\text { Diameter }<1 \mathrm{~cm}(52.3 \%),<2 \mathrm{~cm}(40.8 \%),>2 \mathrm{~cm} \\
(33 \%)\end{array}$ & Prospective; margin $2 \mathrm{~mm}$ to $>10 \mathrm{~mm}$ \\
\hline Thomas $1994(n=54)$ & Pinna & $0.11(0.04$ to 0.23$)$ & $\begin{array}{c}\text { Stages I (52\%), II (37\%), III (0\%), IV }(11 \%) \text {; } \\
\text { differentiation: well }(68.5 \%) \text {, moderate }(9.3 \%) \text {, poor } \\
(7.4 \%)\end{array}$ & $\begin{array}{l}\text { Retrospective; wedge excision to } \\
\text { complex surgical procedure }\end{array}$ \\
\hline Thomas $2003(n=26)$ & All & $0.00(0.00$ to 0.13$)$ & $\begin{array}{c}\text { Average diameter } 16.9 \mathrm{~mm} \text {, diameter }>10 \mathrm{~mm}(26 \%) \text {; } \\
\text { differentiation: well }(57.8 \%) \text {, moderate }(38.5 \%) \text {, poor } \\
(3.8 \%)\end{array}$ & $\begin{array}{l}\text { Prospective; margin based on } \\
\text { diagnosis and surgeon's preference }\end{array}$ \\
\hline
\end{tabular}




\section{Table 3| Recurrence and death from disease after Mohs micrographic surgery}

\begin{tabular}{|c|c|c|c|c|c|c|c|}
\hline \multirow[b]{2}{*}{$\begin{array}{l}\text { Study and No of } \\
\text { patients }\end{array}$} & \multirow[b]{2}{*}{ Site } & \multirow[b]{2}{*}{ Follow-up } & \multicolumn{5}{|c|}{ Proportion with outcome $(95 \% \mathrm{Cl})$} \\
\hline & & & $\begin{array}{l}\text { Local } \\
\text { recurrence }\end{array}$ & $\begin{array}{c}\text { Regional } \\
\text { recurrence }\end{array}$ & $\begin{array}{c}\text { Distant } \\
\text { metastases }\end{array}$ & $\begin{array}{l}\text { Unspecified } \\
\text { recurrence }\end{array}$ & $\begin{array}{c}\text { Patient died } \\
\text { of disease }\end{array}$ \\
\hline $\begin{array}{l}\text { Anderson } 1982 \\
(\mathrm{n}=8)\end{array}$ & Eyelid & $\begin{array}{c}\text { Average } 36 \\
\text { months (range } \\
1-57)\end{array}$ & $\begin{array}{c}0.00(0.00 \text { to } \\
0.37)\end{array}$ & $\begin{array}{c}0.12(0.00 \text { to } \\
0.53)\end{array}$ & $\begin{array}{c}0.12(0.00 \text { to } \\
0.53)\end{array}$ & - & $\begin{array}{c}0.12(0.00 \text { to } \\
0.53)\end{array}$ \\
\hline $\begin{array}{l}\text { Brantsch } 2008 \\
(n=615)\end{array}$ & All & $\begin{array}{c}\text { Mean } 43 \text { months } \\
\text { (range } 1-165 \text { ) }\end{array}$ & $\begin{array}{c}0.03(0.02 \text { to } \\
0.04)\end{array}$ & $\begin{array}{c}0.04(0.03 \text { to } \\
0.06)\end{array}$ & - & - & $\begin{array}{c}0.01(0.01 \text { to } \\
0.03)\end{array}$ \\
\hline
\end{tabular}

Prognostic features*

No details

\begin{tabular}{|c|c|c|c|c|c|c|c|c|}
\hline & & & & & & & & $\begin{array}{l}\text { good (53\%), moderate (22\%), poor } \\
(25 \%) \text {; desmoplasia (8\%); } \\
\text { immunosuppression }(5 \%)\end{array}$ \\
\hline $\begin{array}{l}\text { Cherpelis } 2002 \\
(n=186)\end{array}$ & Various & $\begin{array}{c}6 \text { months to } 10 \\
\text { years }\end{array}$ & - & $\begin{array}{c}0.08 \text { (0.04 to } \\
0.12)\end{array}$ & - & - & - & $\begin{array}{c}\text { Diameter >20 mm (20\%); Clark } \\
\text { level V (28\%); poorly differentiated } \\
(9.5 \%) \text {; perineural invasion }(4 \%)\end{array}$ \\
\hline $\begin{array}{l}\text { Dzubow } 1982 \\
(n=171)\end{array}$ & All & $\begin{array}{c}\text { Mean } 18.6 \\
\text { months (range } \\
1-136)\end{array}$ & $\begin{array}{c}0.04(0.01 \text { to } \\
0.07)\end{array}$ & - & - & - & - & $\begin{array}{c}\text { Diameter 1-9 mm (18.7\%), 10-49 } \\
\mathrm{mm}(68.7 \%),>50 \mathrm{~mm}(12.6 \%)\end{array}$ \\
\hline $\begin{array}{l}\text { Leibovitch } 2005 \\
(\mathrm{n}=229)\end{array}$ & All & 5 years & $\begin{array}{c}0.03(0.01 \text { to } \\
0.06)\end{array}$ & - & $\begin{array}{c}0.00(0.00 \text { to } \\
0.02)\end{array}$ & - & - & $\begin{array}{c}\text { Diameter }<1 \mathrm{~cm}(25.6 \%), 1-1.9 \mathrm{~cm} \\
(46.2 \%), 2-2.9 \mathrm{~cm}(15.4 \%), 3-3.9 \\
\mathrm{~cm}(6.6 \%), 4-4.9 \mathrm{~cm}(2.3 \%), 5-5.9 \\
\mathrm{~cm}(1 \%), 6-7.9 \mathrm{~cm}(0.5 \%), 8-10 \mathrm{~cm} \\
(0.1 \%) ; \text { differentiation: well } \\
(34.8 \%), \text { moderate }(36.4 \%), \text { poor } \\
(6 \%) \text {; acantholytic }(10.4 \%)\end{array}$ \\
\hline
\end{tabular}

\begin{tabular}{|c|c|c|c|c|c|c|c|c|}
\hline & & & & & & & & $(6 \%) ;$ acantholytic $(10.4 \%)$ \\
\hline $\begin{array}{l}\text { Malhotra } 2004 \\
(n=56)\end{array}$ & Periocular & $\begin{array}{c}\text { Mean } 77.3 \\
\text { months }\end{array}$ & $\begin{array}{c}0.04(0.00 \text { to } \\
0.12)\end{array}$ & - & - & - & - & $\begin{array}{c}\text { Diameter } 0-0.9 \mathrm{~cm}(57 \%), 1-1.9 \mathrm{~cm} \\
(38 \%), 2-2.9 \mathrm{~cm}(5 \%) \text {; perineural } \\
\text { invasion (4.3\%) }\end{array}$ \\
\hline
\end{tabular}

\begin{tabular}{|c|c|c|c|c|c|c|c|c|}
\hline Mohs $1976(n=615)$ & Various & Up to 5 years & - & - & - & $\begin{array}{c}0.01(0.00 \text { to } \\
0.02)\end{array}$ & - & No data \\
\hline $\begin{array}{l}\text { Pugliano-Mauro } \\
2010(n=231)\end{array}$ & "High risk" & Mean 3.9 years & $\begin{array}{c}0.01(0.00 \text { to } \\
0.04)\end{array}$ & $\begin{array}{c}0.02(0.00 \text { to } \\
0.04)\end{array}$ & - & - & $\begin{array}{c}0.00(0.00 \text { to } \\
0.02)\end{array}$ & $\begin{array}{l}\text { "High risk": diameter average } 1.5 \\
\text { cm (standard deviation } 0.7) ; \\
\text { immunosuppression (20\%) }\end{array}$ \\
\hline $\begin{array}{l}\text { Silapunt } 2005 \\
(\mathrm{n}=87)\end{array}$ & Auricle & 2 years & $\begin{array}{c}0.06(0.02 \text { to } \\
0.13)\end{array}$ & - & $\begin{array}{c}0.00(0.00 \text { to } \\
0.04)\end{array}$ & - & $\begin{array}{c}0.00(0.00 \text { to } \\
0.04)\end{array}$ & Average surface area $3.04 \mathrm{~cm}^{2}$ \\
\hline Skaria $2010(n=54)$ & $\begin{array}{c}\text { Not } \\
\text { specified }\end{array}$ & $\begin{array}{l}\text { Mean } 59.6 \\
\text { months }\end{array}$ & - & - & - & $\begin{array}{c}0.02(0.00 \text { to } \\
0.10)\end{array}$ & - & No data \\
\hline
\end{tabular}

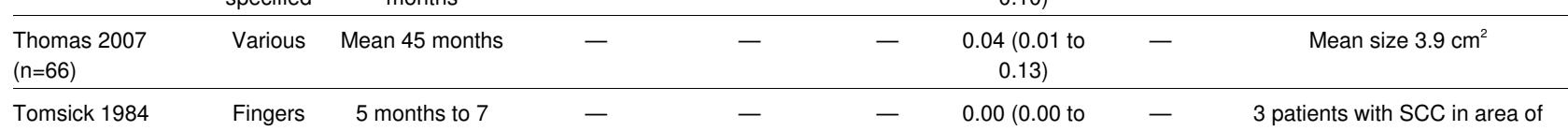

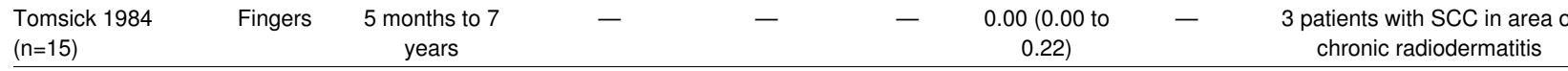

\begin{tabular}{|c|c|c|c|c|c|c|c|c|}
\hline$(n=15)$ & & years & & & & J.८ट) & & crironic radiodermatis \\
\hline Turner $2000(n=48)$ & All & Mean 3.4 years & $\begin{array}{c}0.02(0.00 \text { to } \\
0.11)\end{array}$ & $\begin{array}{c}0.04(0.01 \text { to } \\
0.14)\end{array}$ & $\begin{array}{c}0.02(0.00 \text { to } \\
0.11)\end{array}$ & - & - & $\begin{array}{c}\text { Median diameter } 15 \mathrm{~mm} \text { (range } \\
3-40) \text {; median depth } 2 \mathrm{~mm} \text { (range } \\
0.4-25) \text {; differentiation: grades } 1 \\
(37.2 \%), 2(44.2 \%), 3(14 \%), 4 \\
(4.6 \%) \text {; vascular invasion }(16 \%)\end{array}$ \\
\hline
\end{tabular}

\begin{tabular}{lccccccc}
\hline $\begin{array}{l}\text { Van der Eerden } \\
2010(n=74)\end{array}$ & $\begin{array}{c}\text { Head and } \\
\text { neck }\end{array}$ & Mean 24 months & $\begin{array}{c}0.03(0.00 \text { to } \\
0.09)\end{array}$ & $\begin{array}{c}0.01(0.00 \text { to } \\
0.07)\end{array}$ & - & - & - \\
\hline Vuyk 2001 $(n=53)$ & $\begin{array}{c}\text { Head and } \\
\text { neck }\end{array}$ & Mean 33 months & $\begin{array}{c}0.02(0.00 \text { to } \\
0.10)\end{array}$ & - & - & - & No data \\
\hline $\begin{array}{l}\text { Yoon 1992 }(\mathrm{n}=16) \\
\text { External } \\
\text { ear }\end{array}$ & $\begin{array}{c}6 \text { months to } 20 \\
\text { years }\end{array}$ & - & - & - & $\begin{array}{c}0.31(0.11 \text { to } \\
0.59)\end{array}$ & - & $\begin{array}{c}\text { Stages 0-IV (only data for stage I-II } \\
\text { included) }\end{array}$ \\
\hline
\end{tabular}

*Percentages indicate proportion of patients in study. 


\begin{tabular}{|c|c|c|c|c|c|c|c|c|}
\hline \multirow[b]{2}{*}{$\begin{array}{l}\text { Study and No } \\
\text { of patients }\end{array}$} & \multirow[b]{2}{*}{ Site $^{\star}$} & \multirow[b]{2}{*}{ Radiotherapy dose } & \multirow[b]{2}{*}{ Follow-up } & \multicolumn{4}{|c|}{ Proportion with outcome $(95 \% \mathrm{Cl})$} & \multirow[b]{2}{*}{ Prognostic features* } \\
\hline & & & & $\begin{array}{l}\text { Local } \\
\text { recurrence }\end{array}$ & $\begin{array}{l}\text { Regional } \\
\text { recurrence }\end{array}$ & $\begin{array}{l}\text { Unspecified } \\
\text { recurrence }\end{array}$ & $\begin{array}{l}\text { Patient } \\
\text { died of } \\
\text { disease }\end{array}$ & \\
\hline $\begin{array}{l}\text { Abbatucci } 1989 \\
(n=179)\end{array}$ & Face & $\begin{array}{c}\text { Superficial, } 0.5-1 \mathrm{~cm} \text { peripheral } \\
\text { margin, } 1 \mathrm{~mm} \text { deep margin. } \\
\text { Most doses } 30.6 \mathrm{~Gy}, 3 \\
\text { fractions, } 14 \text { days }\end{array}$ & Minimum 2 years & $\begin{array}{c}0.03(0.01 \text { to } \\
0.06)\end{array}$ & - & - & - & $\begin{array}{c}\text { Diameter }<1.6 \mathrm{~cm} \text { to } \geq 4 \\
\mathrm{~cm}\end{array}$ \\
\hline $\begin{array}{l}\text { Barysch } 2012 \\
(n=177)\end{array}$ & $\begin{array}{l}\text { All (head } \\
\text { and neck } \\
87 \%)\end{array}$ & $\begin{array}{l}\text { Superficial, beryllium } \\
\text { windowed, soft } x \text { rays }\end{array}$ & $\begin{array}{l}\text { Mean } 4.9 \text { years } \\
\text { (SD } 4.7,95 \% \mathrm{Cl} \\
4.2 \text { to } 5.6)\end{array}$ & $\begin{array}{c}0.14(0.10 \text { to } \\
0.20)\end{array}$ & $\begin{array}{l}0.01(0.00 \\
\text { to } 0.03)\end{array}$ & - & - & $\begin{array}{c}\text { Mean area } 3.5 \mathrm{~cm}^{2} \text {; } \\
\text { differentiation: good } \\
(66.7 \%) \text {, moderate } \\
(22.4 \%), \text { poor }(10.9 \%)\end{array}$ \\
\hline $\begin{array}{l}\text { Grosch } 1979 \\
(n=5)\end{array}$ & $\begin{array}{l}\text { Head and } \\
\text { hand }\end{array}$ & $\begin{array}{c}\text { 6-10 meV electron beam, total } \\
\text { dose } 4000-6000 \text { rads, } 10-20 \\
\text { fractions, } 14-28 \text { days }\end{array}$ & $\begin{array}{l}\text { Mean } 15 \text { months } \\
\text { (range 6-33) }\end{array}$ & - & - & $\begin{array}{c}0.00(0.00 \text { to } \\
0.52)\end{array}$ & - & No data \\
\hline $\begin{array}{l}\text { Holmes } 1982 \\
(n=67)\end{array}$ & Various & $\begin{array}{l}\text { Short distance cobalt unit, } \\
5000-5500 \text { cGy, 10-15 } \\
\text { fractions, } 2-3 \text { weeks }\end{array}$ & $2-8$ years & - & - & $\begin{array}{c}0.00(0.00 \text { to } \\
0.05)\end{array}$ & $\begin{array}{c}0.00(0.00 \text { to } \\
0.05)\end{array}$ & No data \\
\hline $\begin{array}{l}\text { Honeycutt } 1973 \\
(\mathrm{n}=18)\end{array}$ & Various & $\begin{array}{c}X \text { rays, total dose } 4500 \text { rads, } 9 \\
\text { or } 15 \text { fractions }\end{array}$ & $\begin{array}{c}4 \text { years (range } \\
4-8)\end{array}$ & - & - & $\begin{array}{c}0.00(0.00 \text { to } \\
0.18)\end{array}$ & - & $\begin{array}{c}\text { Diameter }<2 \mathrm{~cm}(39 \%), \\
>2 \mathrm{~cm}(61 \%)\end{array}$ \\
\hline $\begin{array}{l}\text { Hunter } 1982 \\
(n=26)\end{array}$ & Pinna & $\begin{array}{c}10 \text { meV electron beam, total } \\
\text { dose } 4500-5500 \text { cGy, } 8-15 \\
\text { daily fractions }\end{array}$ & $\begin{array}{c}\text { Average } 44 \\
\text { months (range } \\
12-136)\end{array}$ & - & - & $\begin{array}{c}0.11(0.02 \text { to } \\
0.30)\end{array}$ & $\begin{array}{c}0.08(0.01 \text { to } \\
0.25)\end{array}$ & $\begin{array}{c}\text { Mean duration } 26 \\
\text { months (range 1-186) }\end{array}$ \\
\hline $\begin{array}{l}\text { Knox } 1987 \\
(\mathrm{n}=101)\end{array}$ & All & $\begin{array}{c}\text { Total dose } 4000-5000 \text { rads, } \\
500 \text { or } 1000 \text { rads every other } \\
\text { day, } \leq 10 \text { fractions }\end{array}$ & $>1$ year & - & - & $\begin{array}{l}0.02(0.00 \text { to } \\
0.07)\end{array}$ & - & $\begin{array}{c}\text { Diameter }<2 \mathrm{~cm}(79 \%) \\
>2 \mathrm{~cm}(21 \%)\end{array}$ \\
\hline $\begin{array}{l}\text { Kwan } 2004 \\
(n=37)\end{array}$ & Various & $\begin{array}{l}\text { Orthovolt x rays, electrons, } \\
\text { megavoltage photons, or } \\
\text { combination of electrons and } \\
\text { photons; Total dose }<4000 \text { cGy } \\
\text { to }>6000 \text { cGy, } 5-25 \text { fractions }\end{array}$ & $\begin{array}{c}\text { Median } 42 \\
\text { months (range } \\
1.4-97.1)\end{array}$ & $\begin{array}{l}0.30(0.16 \text { to } \\
0.47) \\
\text { ("locoregional } \\
\text { recurrence") }\end{array}$ & - & - & - & $\begin{array}{c}\text { Tumour stages T2 } \\
(19 \%), \text { T3 }(65 \%), \text { T4 } \\
(16 \%)\end{array}$ \\
\hline $\begin{array}{l}\text { Matthiesen } 2011 \\
(n=3)\end{array}$ & $\begin{array}{l}\text { Cheek and } \\
\text { forehead }\end{array}$ & $\begin{array}{l}\text { 3D conformal radiotherapy with } \\
6 \mathrm{mV} \text { photons or intensity } \\
\text { modulated radiotherapy with } 6 \\
\mathrm{mV} \text { photons; total dose } \\
7425-7980 \mathrm{cGy}, 33-35 \text { fractions }\end{array}$ & $\begin{array}{c}\text { Mean } 14.3 \\
\text { months (range } \\
4-36)\end{array}$ & - & - & $\begin{array}{c}0.67 \text { (0.09 to } \\
0.99)\end{array}$ & $\begin{array}{c}0.67(0.09 \text { to } \\
0.99)\end{array}$ & $\begin{array}{c}\text { All tumour stage } 4 \\
\text { volumes } 126 \mathrm{~cm}^{3}, 175 \\
\mathrm{~cm}^{3}, 341 \mathrm{~cm}^{3} ; \text { bone } \\
\text { involvement in } 1 \text { tumour }\end{array}$ \\
\hline $\begin{array}{l}\text { Podd } 1992 \\
(\mathrm{n}=17)\end{array}$ & Lower leg & $\begin{array}{l}\text { Photon based; dose not } \\
\text { specified }\end{array}$ & Not specified & $\begin{array}{c}0.06(0.00 \text { to } \\
0.29)\end{array}$ & - & - & - & No data \\
\hline $\begin{array}{l}\text { Rank } 1973 \\
(\mathrm{n}=231)\end{array}$ & $\begin{array}{c}\text { Not } \\
\text { specified }\end{array}$ & No details & 2 years & $\begin{array}{c}0.03(0.01 \text { to } \\
0.06)\end{array}$ & - & - & - & No data \\
\hline $\begin{array}{l}\text { Shiffman } 1975 \\
(\mathrm{n}=2)\end{array}$ & Pinna & No details & $\begin{array}{c}<1 \text { year to }>3 \\
\text { years }\end{array}$ & $\begin{array}{c}0.5(0.01 \text { to } \\
0.99)\end{array}$ & $\begin{array}{c}0.5(0.01 \text { to } \\
0.99)\end{array}$ & - & $\begin{array}{c}0.5(0.01 \text { to } \\
0.99)\end{array}$ & $\begin{array}{c}1 \text { SCC } 2-4 \mathrm{~cm} \text { (no data } \\
\text { for second SCC) }\end{array}$ \\
\hline $\begin{array}{l}\text { Stoll } 1964 \\
(n=62)\end{array}$ & Nose & $\begin{array}{c}\text { Roentgen therapy } 4000-8000 \\
\text { rads in } 300-500 \text { rads fractions } \\
\text { over } \leq 26 \text { days }\end{array}$ & $\begin{array}{l}<6 \text { months to } 144 \\
\text { months }\end{array}$ & $\begin{array}{c}0.03(0.00 \text { to } \\
0.11)\end{array}$ & - & - & - & $\begin{array}{c}\text { Diameter }<0.5 \mathrm{~cm} \\
(33.9 \%), 0.5-1 \mathrm{~cm} \\
(56.4 \%), 1.5-2.5 \mathrm{~cm} \\
(4.8 \%),>2.5 \mathrm{~cm}(4.8 \%)\end{array}$ \\
\hline $\begin{array}{l}\text { Tsao } 2002 \\
(\mathrm{n}=93)\end{array}$ & Nose & $\begin{array}{c}\text { Orthovoltage ( } 81 \%) \text {; electrons } \\
(14 \%), \text { megavoltage } x \text { rays } \\
(4 \%) \text {; high energy photons } \\
(1 \%)\end{array}$ & $\begin{array}{l}\text { Median } 2.9 \text { years } \\
(0.2-10.4)\end{array}$ & $\begin{array}{c}0.06(0.02 \text { to } \\
0.14)\end{array}$ & $\begin{array}{l}0.02(0.00 \\
\text { to } 0.08)\end{array}$ & - & $\begin{array}{c}0.03(0.01 \text { to } \\
0.09)\end{array}$ & $\begin{array}{c}\text { Tumour stages T1 } \\
(64 \%), \text { T2 }(11.7 \%), \text { T3 } \\
\text { (0\%), T4 }(7.4 \%) ; \text { stage } \\
\text { not evaluable }(17 \%) ; \\
5 \text { immunosuppressed } \\
\text { patients }\end{array}$ \\
\hline
\end{tabular}

$\mathrm{SD}=$ standard deviation; 3D=three dimensional.

*Percentages indicate proportion of patients in study. 


\begin{tabular}{|c|c|c|c|c|c|c|}
\hline $\begin{array}{l}\text { Study and No of } \\
\text { SCCs }\end{array}$ & Site & Brachytherapy modality and dose & Follow-up & $\begin{array}{l}\text { Proportion with } \\
\text { local recurrence } \\
(95 \% \mathrm{Cl})\end{array}$ & Prognostic features ${ }^{*}$ & Study design \\
\hline Allan $1998(n=3)$ & Pinna & $\begin{array}{l}\text { High dose rate microselectron }{ }^{192} \mathrm{Ir} \\
\text { plane or mould; } 42.5-45 \mathrm{~Gy}, 8 \\
\text { fractions }\end{array}$ & $\begin{array}{l}\text { Minimum } 18 \\
\text { months }\end{array}$ & $0.00(0.00$ to 0.71$)$ & Confined to skin of pinna & Prospective \\
\hline Ashby $1989(n=48)$ & $\begin{array}{l}\text { Any }(33 \% \\
\text { head and } \\
\text { neck) }\end{array}$ & $\begin{array}{l}\text { Radon mould, 35-40 Gy; overall } \\
\text { treatment time } 6 \text { days } 20 \mathrm{~h}\end{array}$ & $\begin{array}{l}45.3 \text { months } \\
(1-146)\end{array}$ & $0.04(0.01$ to 0.14$)$ & $\begin{array}{l}\text { Median tumour volume } 1099 \\
\mathrm{~mm}^{3}\left(16-6300 \mathrm{~mm}^{3}\right) \\
\text { differentiation: well }(84 \%) \\
\text { moderate }(16 \%)\end{array}$ & Retrospective \\
\hline Guix $2000(n=18)$ & Facial & $\begin{array}{l}\text { High dose rate custom made }{ }^{192} \mathrm{Ir} \\
\text { surface mould, } 60-65 \mathrm{~Gy}, 33-36 \\
\text { fractions ( }<4 \mathrm{~cm} \text { diameter) or boosted } \\
\text { to } 75-80 \text { Gy after } 3 \text { week pause }(>4 \\
\mathrm{cm} \text { diameter) }\end{array}$ & $\begin{array}{l}\text { Minimum } 12 \\
\text { months }\end{array}$ & $0.06(0.00$ to 0.27$)$ & $\begin{array}{c}\text { Diameter (all SCCs) }<2 \mathrm{~cm} \\
(23.5 \%), 2-5 \mathrm{~cm}(73.5 \%), 5-8 \\
\mathrm{~cm}(3 \%) ; \text { perineural invasion } \\
(5.8 \%) ; \text { lymphatic invasion } \\
(14.7 \%)\end{array}$ & Prospective \\
\hline Lee $1997(n=3)$ & $\begin{array}{l}\text { Scalp, neck, } \\
\text { face }\end{array}$ & $\begin{array}{l}{ }^{166} \mathrm{Ho} \text { impregnated patch for total } 30 \\
\min \text { to } 1 \mathrm{~h}, 50 \mathrm{~Gy}\end{array}$ & 8-20 months & $0.00(0.00$ to 0.71$)$ & $\begin{array}{c}\text { Selected superficial tumours } \\
\text { only }\end{array}$ & Prospective \\
\hline Rio $2005(n=5)$ & Facial & $\begin{array}{l}\text { Interstitial brachytherapy with }{ }^{192} \mathrm{Ir} \\
\text { wires, average dose } 50-65 \mathrm{~Gy} \text {, mean } \\
\text { implantation time } 79 \mathrm{~h}\end{array}$ & $\begin{array}{l}\text { Median } 55 \text { months } \\
\quad \text { (range 6-132) }\end{array}$ & $0.00(0.00$ to 0.52$)$ & Lip carcinomas excluded & Retrospective \\
\hline $\begin{array}{l}\text { Svodoba } 1995 \\
(n=11)\end{array}$ & Any & $\begin{array}{l}\text { High dose rate }{ }^{192} \mathrm{Ir} \text { afterloaded } \\
\text { moulds, } 12-50 \text { Gy, } 1-15 \text { fractions }\end{array}$ & $\begin{array}{l}\text { Average } 9.6 \text { months } \\
\quad \text { (range } 5-22 \text { ) }\end{array}$ & $0.00(0.00$ to 0.28$)$ & Area $<0.5$ to $>6.1 \mathrm{~cm}^{2}$ & Prospective \\
\hline
\end{tabular}




\begin{tabular}{|c|c|c|c|c|c|}
\hline $\begin{array}{l}\text { Study and No of } \\
\text { SCCs }\end{array}$ & Reasons for adjuvant radiotherapy & Surgical treatment & $\begin{array}{l}\text { Site of adjuvant } \\
\text { radiotherapy } \\
\text { (local/regional) }\end{array}$ & $\begin{array}{l}\text { Dose of adjuvant } \\
\text { radiotherapy }\end{array}$ & Follow-up \\
\hline Barrett $1993(n=3)$ & $\begin{array}{l}\text { Head and neck perineural invasion } \\
\text { (asymptomatic) }\end{array}$ & $\begin{array}{l}\text { Surgical excision or } \\
\text { Mohs micrographic } \\
\text { surgery }\end{array}$ & Not specified & $\begin{array}{l}\text { Mean } 51.7 \text { Gy, } 18-22 \\
\text { fractions }\end{array}$ & $\begin{array}{l}\text { Mean } 28.3 \text { months } \\
\quad \text { (range 18-37) }\end{array}$ \\
\hline Cottel $1982(n=2)$ & $\begin{array}{l}\text { Head and neck perineural invasion, both } \\
\text { symptomatic (infraorbital and supraorbital } \\
\text { nerves); patients with the "most difficult } \\
\text { cases" selected for adjuvant radiotherapy }\end{array}$ & $\begin{array}{l}\text { Mohs micrographic } \\
\text { surgery }\end{array}$ & $\begin{array}{l}\text { Primary site and course } \\
\text { of involved cranial nerve }\end{array}$ & $\begin{array}{c}4600-5000 \text { rads }(200 \\
\text { rads/day over } 4.5-6 \\
\text { weeks })\end{array}$ & $\begin{array}{l}\text { Mean } 30 \text { months } \\
\text { (range } 24-36 \text { ) for } \\
\text { adjuvant radiotherapy }\end{array}$ \\
\hline $\begin{array}{l}\text { DeAmbrosis } 2010 \\
(n=6)\end{array}$ & $\begin{array}{l}\text { Head and neck perineural invasion, nerve } \\
\text { diameter } 0.15-0.4 \mathrm{~mm} \text { (all asymptomatic) } \\
\text { but indications for radiotherapy inconsistent }\end{array}$ & Excision & Not specified & Not specified & $\begin{array}{l}\text { Mean } 104.8 \text { months } \\
\quad \text { (range } 44-218)\end{array}$ \\
\hline Geist $2008(n=7)$ & $\begin{array}{l}\text { Head and neck perineural invasion (all } \\
\text { incidental) }\end{array}$ & $\begin{array}{l}\text { Mohs micrographic } \\
\text { surgery }\end{array}$ & $\begin{array}{l}\text { Tumour bed and first } \\
\text { echelon lymphatics and } \\
\text { course of involved nerve }\end{array}$ & $\begin{array}{l}\text { Mean dose } 57.9 \text { Gy } \\
\text { (range } 52-66), 20-33 \\
\text { fractions }\end{array}$ & $\begin{array}{l}\text { Mean } 10.4 \text { months } \\
\quad \text { (range } 4-20)\end{array}$ \\
\hline Khan $1999(n=26)$ & $\begin{array}{c}\text { No specific reasons. Prospective cohort } \\
\text { with SCC diameter }>2 \mathrm{~cm}\end{array}$ & Excision & $\begin{array}{l}\text { Elective irradiation of } \\
\text { draining lymph nodes }\end{array}$ & $\begin{array}{l}\text { Total dose } 45 \text { Gy, } 20 \\
\text { fractions }\end{array}$ & Up to 12 months \\
\hline Lifeso $1990(n=11)$ & Unclear & $\begin{array}{l}\text { Amputation or wide } \\
\text { local excision }\end{array}$ & Regional lymph nodes & $\begin{array}{c}4500 \text { rads, } 20 \text { fractions, } \\
4 \text { weeks }\end{array}$ & $\begin{array}{l}\text { Mean } 37 \text { months } \\
\text { (range 24-86) }\end{array}$ \\
\hline $\begin{array}{l}\text { Osguthorpe } 1997 \\
(n=4)\end{array}$ & $\begin{array}{l}\text { Head and neck perineural invasion; } \\
\text { supraorbital, infraorbital, and buccal } \\
\text { nerves; regional lymphatic or perivascular } \\
\text { spread; neural spread on multiple nerves } \\
\text { from primary tumour site; extension } \\
\text { through bony foramen, needing extended } \\
\text { resection }\end{array}$ & $\begin{array}{l}\text { Mohs micrographic } \\
\text { surgery with or without } \\
\text { intracranial clearance }\end{array}$ & Not specified & $\begin{array}{c}\text { Mean } 56.2 \text { Gy (range } \\
50-65)\end{array}$ & $\begin{array}{l}49.5 \text { months (range } \\
6-99)\end{array}$ \\
\hline $\begin{array}{l}\text { Shiffman } 1975 \\
(n=4)\end{array}$ & Not specified & Surgery & Not specified & Not specified & $<1$ year to $>3$ years \\
\hline Veness $1999(n=6)$ & $\begin{array}{l}\text { Patients undergoing cardiothoracic } \\
\text { transplantation who developed "aggressive } \\
\text { cutaneous malignancies," but not specified } \\
\text { how patients were selected to have } \\
\text { adjuvant radiotherapy }\end{array}$ & Wide local excision & Not specified & Mean dose 52 Gy & $\begin{array}{l}\text { Mean } 25.8 \text { months } \\
\quad \text { (range 8-54) }\end{array}$ \\
\hline
\end{tabular}


Table 7| Pooled estimates of SCC specific outcomes after adjuvant radiotherapy

Proportion $(95 \% \mathrm{Cl})$ of patients, $\mathrm{I}^{2}$, No of patients

Local recurrence Regional recurrence Distant metastases

Patient died from disease

Adjuvant radiotherapy for

$18.2 \%$ (3.8\% to $39.8 \%$ ), 37\%, $8.3 \%$ ( $1.1 \%$ to $21.4 \%$ ), $0 \%, n=2211.5$ (2.4\% to $26.1 \%$ ), $1 \%, n=22$

$11.1 \%(0.4 \%$ to $33.1 \%), 45 \%$ perineural invasion ${ }^{71-75}$ $\mathrm{n}=22$ $\mathrm{n}=20$

Adjuvant radiotherapy for $11.1 \%(2.4 \%$ to $25.0 \%), 35 \%, \quad 8.5 \%(2.5 \%$ to $17.6 \%), 0 \%, \mathrm{n}=47 \quad 3.2 \%(0.1 \%$ to $10.4 \%), 9 \%$, $13.9 \%(0.05 \%$ to $50.2 \%), 74 \%$, other types of SCC $20,76-78$ $\mathrm{n}=47$ $\mathrm{n}=47$ $\mathrm{n}=21$ 


\begin{tabular}{|c|c|c|c|c|c|}
\hline Study and No of patients & Site & Follow-up & $\begin{array}{l}\text { Proportion }(95 \% \mathrm{Cl}) \text { with } \\
\text { recurrence }\end{array}$ & Prognostic features* & Study design \\
\hline Knox 1967 (n=545) & Various & $>1$ year & $0.00(0.00$ to 0.01$)$ & Diameter <2 cm (91\%), >2 cm (9\%) & Retrospective \\
\hline Honeycutt $1973(n=281)$ & Various & 4-8 years & $0.01(0.00$ to 0.03$)$ & Diameter <2 cm (94\%), >2 cm (6\%) & Retrospective \\
\hline Reschly $2010(n=120)$ & $\begin{array}{l}\text { Exposed body } \\
\text { surface excluding lip } \\
\text { and ear }\end{array}$ & 13-33 months & $\begin{array}{l}\text { Triple cycle: } 0.00(0.00 \text { to } 0.03) \text {; } \\
\text { double cycle: } 0.00 \text { (0.00 to } 0.23)\end{array}$ & Diameter $<2 \mathrm{~cm}$ & Retrospective \\
\hline Shiffman $1975(n=15)$ & Pinna & $<1$ to $>3$ years & $\begin{array}{l}\text { Local recurrence: } 0.20 \text {; regional } \\
\text { recurrence } 0.07\end{array}$ & $\begin{array}{l}\text { Diameter }<2 \mathrm{~cm}(59.6 \%), 2-4 \mathrm{~cm} \\
(28.8 \%),>4 \mathrm{~cm}(3.8 \%) ; \text { invasion of } \\
\text { cartilage }(21.1 \%)\end{array}$ & Retrospective \\
\hline Tromovitch $1965(n=29)$ & Not specified & $\begin{array}{l}\text { Average } 6.8 \text { years } \\
\text { (minimum } 5 \text { years) }\end{array}$ & $0.03(0.00$ to 0.18$)$ & No data & Retrospective \\
\hline Werlinger $2002(n=56)$ & Various & Mean 4.1 years & $0.04(0.00$ to 0.12$)$ & $\begin{array}{l}\text { No separate data on } \\
\text { electrodesiccation }\end{array}$ & Retrospective \\
\hline Whiting $1978(n=47)$ & No data & $\begin{array}{l}\text { 6-12 months, then } \\
\text { "thereafter as necessary" }\end{array}$ & $0.04(0.01$ to 0.14$)$ & No data & Retrospective \\
\hline Williamson $1964(n=53)$ & Various & 5 years & 0.04 (0.00 to 0.13$)$ & $\begin{array}{c}\text { Diameter: }<2 \mathrm{~cm}(60.4 \%),>2 \mathrm{~cm} \\
(39.6 \%)\end{array}$ & Retrospective \\
\hline
\end{tabular}




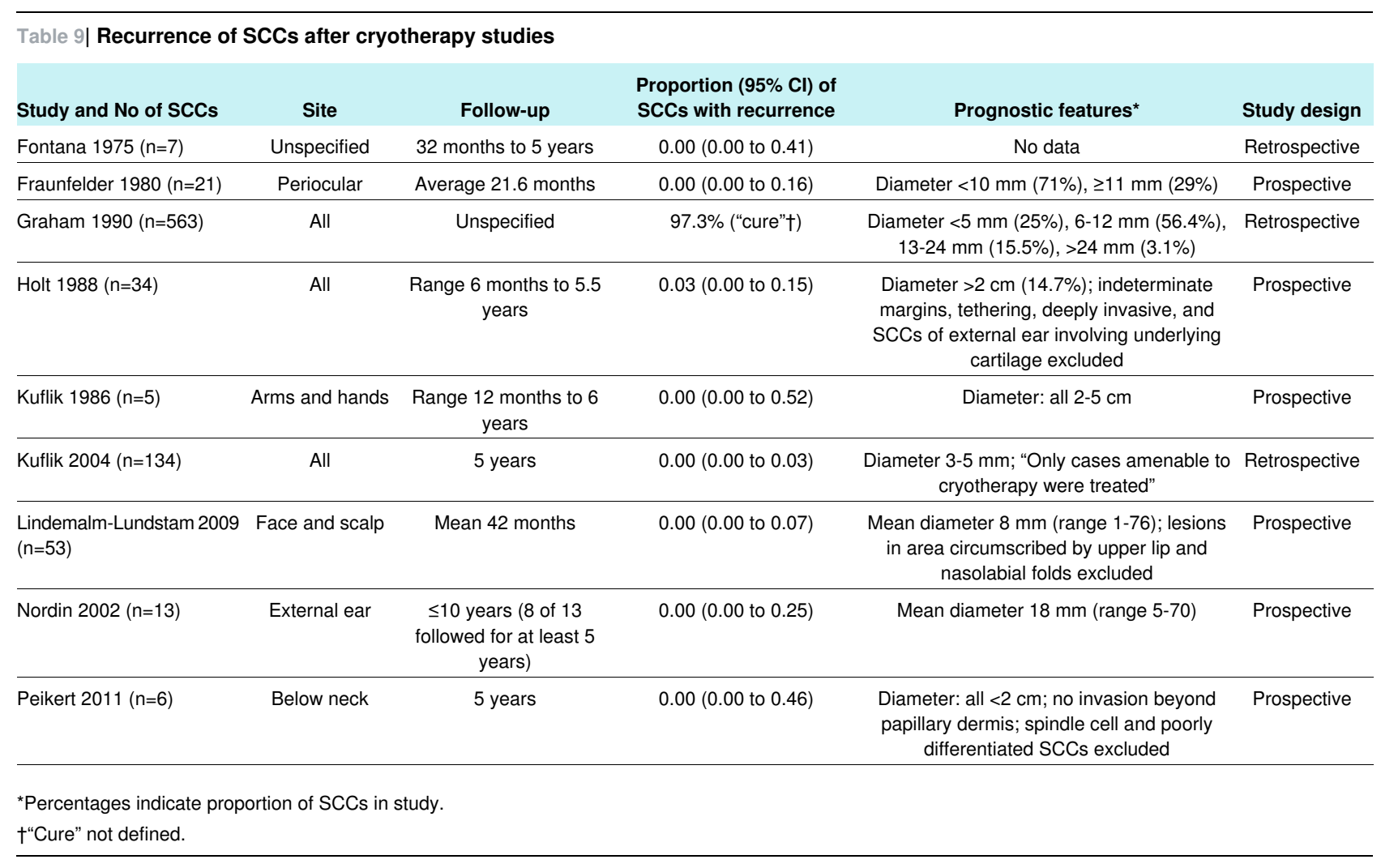




\begin{tabular}{|c|c|c|c|c|}
\hline Study and No of SCCs & $\begin{array}{l}\text { Photosensitiser or occlusion } \\
\text { time }\end{array}$ & Light source, irradiance,dose & Treatment regimen & Prognostic features* \\
\hline Baptista $2006(n=4)$ & Topical 20\% ALA, 4-6 h & $\begin{array}{l}630 \mathrm{~nm} \text { for } 1000 \mathrm{~s} \text { at } 100 \mathrm{~mW} / \mathrm{cm}^{2} \text {; total } \\
\text { dose } 100 \mathrm{~J} / \mathrm{cm}^{2}\end{array}$ & Up to 5 treatments & No data \\
\hline $\begin{array}{l}\text { Calzavara-Pinton } 1995 \\
(\mathrm{n}=18)\end{array}$ & Topical 20\% ALA, 6-8 h & $\begin{array}{c}630 \mathrm{~nm} \text { for } 10-15 \mathrm{~min} \text { until slight pain or } \\
\text { burning stopped at } 100 \mathrm{~mW} / \mathrm{cm}^{2} \text {; total dose } \\
60-80 \mathrm{~J} / \mathrm{cm}^{2}\end{array}$ & $\begin{array}{l}\text { Every other day until area } \\
\text { eroded without clinically } \\
\text { evident tumour, or } \\
\text { stopped when no further } \\
\text { improvement after } 2 \\
\text { further treatments }\end{array}$ & $\begin{array}{l}\text { Diameter: superficial SCCs } \\
\text { median } 18 \mathrm{~mm} \text { (range 12-45); } \\
\text { nodular median } 15 \mathrm{~mm} \text { (range } \\
5-25)\end{array}$ \\
\hline $\begin{array}{l}\text { Calzavara-Pinton } 2008 \\
(\mathrm{n}=71)\end{array}$ & Topical 160 mg/g MAL, $3 \mathrm{~h}$ & $\begin{array}{l}635 \pm 18 \mathrm{~nm} \text { at } 37 \mathrm{~J} / \mathrm{cm}^{2} \text { at irradiance of } 86 \\
\mathrm{~mW} / \mathrm{cm}^{2}\end{array}$ & 2 treatments, 7 days apart & $\begin{array}{c}\text { Mean diameter } 20 \mathrm{~mm} \text { (range } \\
\text { 15-30); depth: Clark levels II } \\
(56 \%), \text { III/IV (44\%) }\end{array}$ \\
\hline Fink-Puchs $1998(\mathrm{n}=35)$ & Topical $20 \%$ ALA oil in water, $4 \mathrm{~h}$ & $\begin{array}{l}\text { Either unfiltered full spectrum visible light } \\
\text { or filtered light of }>515 \mathrm{~nm} \text { or }>570 \mathrm{~nm} \text { or } \\
>610 \mathrm{~nm} \text {, for } 5-30 \mathrm{~min} \text {; median total light } \\
\text { dose } 61 \mathrm{~J} / \mathrm{cm}^{2}\end{array}$ & 1 treatment & $\begin{array}{l}\text { Diameter } 1.6-6 \mathrm{~cm} \text {; depth } \\
\text { confined to papillary dermis }\end{array}$ \\
\hline Fritsch $1998(\mathrm{n}=36)$ & Topical 20\% ALA, 4-6 h & $\begin{array}{l}\text { Incoherent light source } 570-750 \mathrm{~nm} \text { for } 20 \\
\mathrm{~min} ; 80 \mathrm{~mW} / \mathrm{cm}^{2} \text { for superficial SCCs up to } \\
150 \mathrm{~mW} / \mathrm{cm}^{2} \text { for nodular and exulcerated } \\
\text { SCCs; total dose } 96-180 \mathrm{~J} / \mathrm{cm}^{2}\end{array}$ & $\begin{array}{l}\text { Maximum } 3 \text { treatments ( } 1 \\
\text { month apart) }\end{array}$ & $\begin{array}{c}\text { Diameter } 0.5-3.1 \mathrm{~cm} ; 28 \text { SCCs } \\
\text { described as "superficial" } \dagger\end{array}$ \\
\hline Haddad 2004 (n=43) & Topical 20\% ALA, $16 \mathrm{~h}$ & $\begin{array}{l}\text { Non-laser light at } 580-720 \mathrm{~nm} \text { and } \\
1250-1600 \mathrm{~nm} \text { for } 10 \mathrm{~min} \text { at } 100 \mathrm{~J} / \mathrm{cm}^{2}\end{array}$ & $1-3$ treatments & $\begin{array}{l}\text { Mean diameter } 1.4 \pm 0.8 \mathrm{~cm} \\
\text { (range 1-3) }\end{array}$ \\
\hline Harth $1998(n=5)$ & $\begin{array}{l}\text { Modified topical } 20 \% \text { ALA plus } 2 \% \\
\text { EDTA and } 2 \% \text { DMSO, } 12 \mathrm{~h}\end{array}$ & $\begin{array}{l}\text { Red light }(585-720 \mathrm{~nm}) \text { at } 150 \mathrm{~mW} / \mathrm{cm}^{2} \\
\text { and near infrared }(1.25-1.6 \mathrm{~mm}) \text { at } 50 \\
\mathrm{~mW} / \mathrm{cm}^{2} \text { for } 10-15 \mathrm{~min}\end{array}$ & $1-3$ treatments & "Superficial" \\
\hline Kennedy $1990(n=8)$ & Topical 20\% ALA, 3-6 h & $\begin{array}{l}\text { Filtered light }>600 \mathrm{~nm} \text { at } 150-300 \mathrm{~mW} / \mathrm{cm}^{2} \\
\text { for } 3.5-30 \mathrm{~min} \text {; total dose } 15-150 \mathrm{~mW} / \mathrm{cm}^{2}\end{array}$ & $\begin{array}{l}\text { Treatment repeated } \\
\text { weekly for } 2 \text { elevated } \\
\text { SCCs }\end{array}$ & $\begin{array}{l}6 \text { early invasive SCCs; } 2 \\
\text { elevated SCCs }\end{array}$ \\
\hline Lui 1995 (n=2) & Topical 20\% ALA, $3 \mathrm{~h}$ & $\begin{array}{l}\text { Red light at } 19-44 \mathrm{~mW} / \mathrm{cm}^{2} ; \text { total dose } 100 \\
\mathrm{~J} / \mathrm{cm}^{2}\end{array}$ & 1 treatment & Diameter $>5 \mathrm{~mm}$ \\
\hline Wolf $1993(n=6)$ & $\begin{array}{c}\text { Topical 20\% ALA oil in water, 4-8 } \\
\text { h }\end{array}$ & $\begin{array}{l}\text { Unfiltered light at } 100 \mathrm{~mW} / \mathrm{cm}^{2} \text { for } 15 \mathrm{~min} \\
\text { or red light at } 100 \mathrm{~mW} / \mathrm{cm}^{2} \text { for } 30 \mathrm{~min} \text {; total } \\
\text { dose } 90 \mathrm{~J} / \mathrm{cm}^{2}\end{array}$ & $\begin{array}{l}\text { No of treatments not } \\
\text { specified }\end{array}$ & $\begin{array}{l}\text { Diameter } 1-6 \mathrm{~cm} \text {; depth: all } \\
\text { early invasive }\end{array}$ \\
\hline Ziokolwski 2004 (n=23) & $\begin{array}{l}\text { Group 1: topical } 20 \% \text { ALA plus } 5 \% \\
\text { DMSO and } 5 \% \text { EDTA, } 4 \mathrm{~h} \\
\text { occlusion; group 2: topical } 20 \% \text { ALA } \\
\text { plus } 5 \% \text { DMSO, } 5 \% \text { EDTA, and } \\
\text { glycolic acid, } 4 \text { h occlusion }\end{array}$ & $\begin{array}{l}650 \mathrm{~nm} \pm 30 \mathrm{~nm} \text { light at } 100 \mathrm{~mW} / \mathrm{cm}^{2} \text {; total } \\
\text { dose } 85-87.6 \mathrm{~J} / \mathrm{cm}^{2}\end{array}$ & $\begin{array}{l}\text { Up to } 3 \text { sessions of } \\
\text { treatment }\end{array}$ & $\begin{array}{l}\text { Group } 1 \text { diameter 2-7 mm, } \\
\text { group } 2 \text { diameter 2-9 mm }\end{array}$ \\
\hline Feyh $1990(n=5)$ & $\begin{array}{l}\text { Systemic haematoporphyrin } \\
\text { derivative } 2 \mathrm{~h} \text { before photodynamic } \\
\text { therapy; dose not specified }\end{array}$ & $\begin{array}{l}\text { 630nm laser light at } 100 \mathrm{mw} / \mathrm{cm}^{2} \text {; dose } 100 \\
\qquad \mathrm{~J} / \mathrm{cm}^{2}\end{array}$ & - & All tumour stage $\mathrm{T} 1$ \\
\hline Kubler $1999(n=9)$ & $\begin{array}{l}\mathrm{mTHPC} \text { at } 0.15 \mathrm{mg} / \mathrm{kg} \text {, intravenous, } \\
96 \mathrm{~h} \text { before photodynamic therapy }\end{array}$ & $\begin{array}{l}652 \mathrm{~nm} \text { red light at } 100 \mathrm{~mW} / \mathrm{cm}^{2} \text {; total dose } \\
\qquad 20 \mathrm{~J} / \mathrm{cm}^{2}\end{array}$ & - & No data \\
\hline $\begin{array}{l}\text { Pennington } 1988 \\
(\mathrm{n}=32)\end{array}$ & $\begin{array}{c}\text { Systemic haematoporphyrin } \\
\text { derivative as } 5 \mathrm{mg} / \mathrm{kg} \text { intravenous } \\
\text { bolus, } 3 \text { days before photodynamic } \\
\text { therapy }\end{array}$ & $630 \mathrm{~nm}$ coherent light at $30 \mathrm{~J} / \mathrm{cm}^{2}$ & - & $\begin{array}{l}\text { Estimated maximal thickness } \\
\qquad<1 \mathrm{~cm}\end{array}$ \\
\hline
\end{tabular}




\section{Table 11| Initial response and recurrence of SCCs after photodynamic therapy}

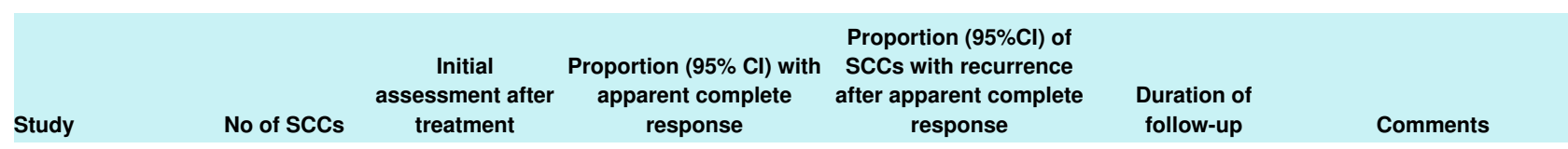

Topical photosenstitiser

\begin{tabular}{lcccccc}
\hline Baptista 2006 & 4 & 1 month & $0.25(0.01$ to 0.80$)$ & $0.00(0.00$ to 0.98$), \mathrm{n}=1$ & Median 38 months & - \\
\hline $\begin{array}{l}\text { Calzavara-Pinton } \\
1995\end{array}$ & $\begin{array}{c}\text { 6 nodular, 12 } \\
\text { superficial }\end{array}$ & 1 month & $\begin{array}{c}0.5(0.12 \text { to } 0.88), 0.83 \\
(0.52 \text { to } 0.98)\end{array}$ & $\begin{array}{ll}0.50(0.01 \text { to } 0.99), \mathrm{n}=2 ; \\
0.00(0.00 \text { to } 0.71), \mathrm{n}=3\end{array}$ & 29 months (24-36). & $\begin{array}{l}\text { Residual tumour in } 1 \text { of } 2 \\
\text { biopsied apparently } \\
\text { responsive nodular SCCs, } \\
\text { and in } 1 \text { of } 8 \text { biopsied } \\
\text { responsive superficial } \\
\text { SCCs }\end{array}$ \\
\hline
\end{tabular}

\begin{tabular}{|c|c|c|c|c|c|c|}
\hline $\begin{array}{l}\text { Calzavara-Pinton } \\
2008\end{array}$ & $\begin{array}{c}40 \\
\text { microinvasive, } \\
31 \text { invasive }\end{array}$ & 3 months & $\begin{array}{c}0.8 \text { (0.64 to } 0.91), 0.45 \\
(0.27 \text { to } 0.64)\end{array}$ & $\begin{array}{l}0.28(0.14 \text { to } 0.47), n=32 \\
0.43(0.18 \text { to } 0.71), n=14\end{array}$ & $\leq 24$ months & 一 \\
\hline Fink-Puches 1998 & 35 & 2-4 weeks & 0.54 (0.37 to 0.71$)$ & $0.69(0.41$ to 0.89$), n=16$ & $\begin{array}{l}\text { Median } 8 \text { months } \\
\quad \text { (range } 3-47 \text { ) }\end{array}$ & - \\
\hline
\end{tabular}

\begin{tabular}{lccccc}
\hline Fritsch 1998 & 36 & Not specified & $0.75(0.58$ to 0.88$)$ & - & - \\
\hline Haddad 2004 & 43 & 21 days & $0.74(0.59$ to 0.86$)$ & - & - \\
\hline Harth 1998 & 5 & Not specified & $0.8(0.28$ to 0.99) & - \\
\hline Kennedy 1990 & $\begin{array}{l}\text { 2 "elevated," } 6 \\
\text { "early invasive" }\end{array}$ & 2-3 months & $\begin{array}{c}0.00(0.00 \text { to } 0.84), 1.0 \\
(0.54 \text { to } 1.0)\end{array}$ & - \\
\hline
\end{tabular}

\begin{tabular}{llccccc}
\hline Lui 1995 & 2 & 3 months & $0.00(0.00$ to 0.84$)$ & - & - \\
\hline Wolf 1993 & 6 & 4 and/or 8 weeks & $0.83(0.36$ to 1.0$)$ & $0.00(0.00$ to 0.52$), \mathrm{n}=5 \quad 7$ months (range \\
$3-12)$
\end{tabular}

\begin{tabular}{|c|c|c|c|c|c|c|}
\hline Ziokolwski 2004 & $\begin{array}{l}11 \text { (no glycolic } \\
\text { acid), } 12 \text { (plus } \\
\text { glycolic acid) }\end{array}$ & Not specified & $\begin{array}{c}0.64 \text { (0.31 to } 0.89), 1.0 \\
(0.74 \text { to } 1.0)\end{array}$ & - & $\begin{array}{l}\text { "Complete } \\
\text { response" at } 12 \\
\text { months }\end{array}$ & $\begin{array}{l}\text { "Complete response" } \\
\text { defined as no clinically } \\
\text { visible or } 5 \text {-ALA } \\
\text { fluorescence detectable } \\
\text { tumour after } 12 \text { months of } \\
\text { observation }\end{array}$ \\
\hline
\end{tabular}

\section{Systemic photosensitiser}

\begin{tabular}{|c|c|c|c|c|c|c|}
\hline Feyh 1990 & 5 & 2 months & $1.0(0.48$ to 1.0$)$ & 0.00 (0.00 to 0.52$), \mathrm{n}=5$ & Maximum 14 months & - \\
\hline Kubler 1999 & 9 & 3 months & $1.0(0.66$ to 1.0$)$ & $0.00(0.00$ to 0.34$), n=9$ & $\begin{array}{c}\text { Mean } 20 \text { months } \\
\text { (range 8-24) }\end{array}$ & - \\
\hline Pennington 1988 & 32 & 6 weeks & 0.81 (0.64 to 0.93$)$ & $0.5(0.32$ to 0.68$), n=32$ & 6 months & $\begin{array}{l}\text { Authors found no } \\
\text { correlation between } \\
\text { recurrence and presence of } \\
\text { residual tumour on } \\
\text { histology at initial } \\
\text { assessment, and } \\
\text { abandoned trial in view of } \\
\text { results }\end{array}$ \\
\hline
\end{tabular}




\section{Figures}

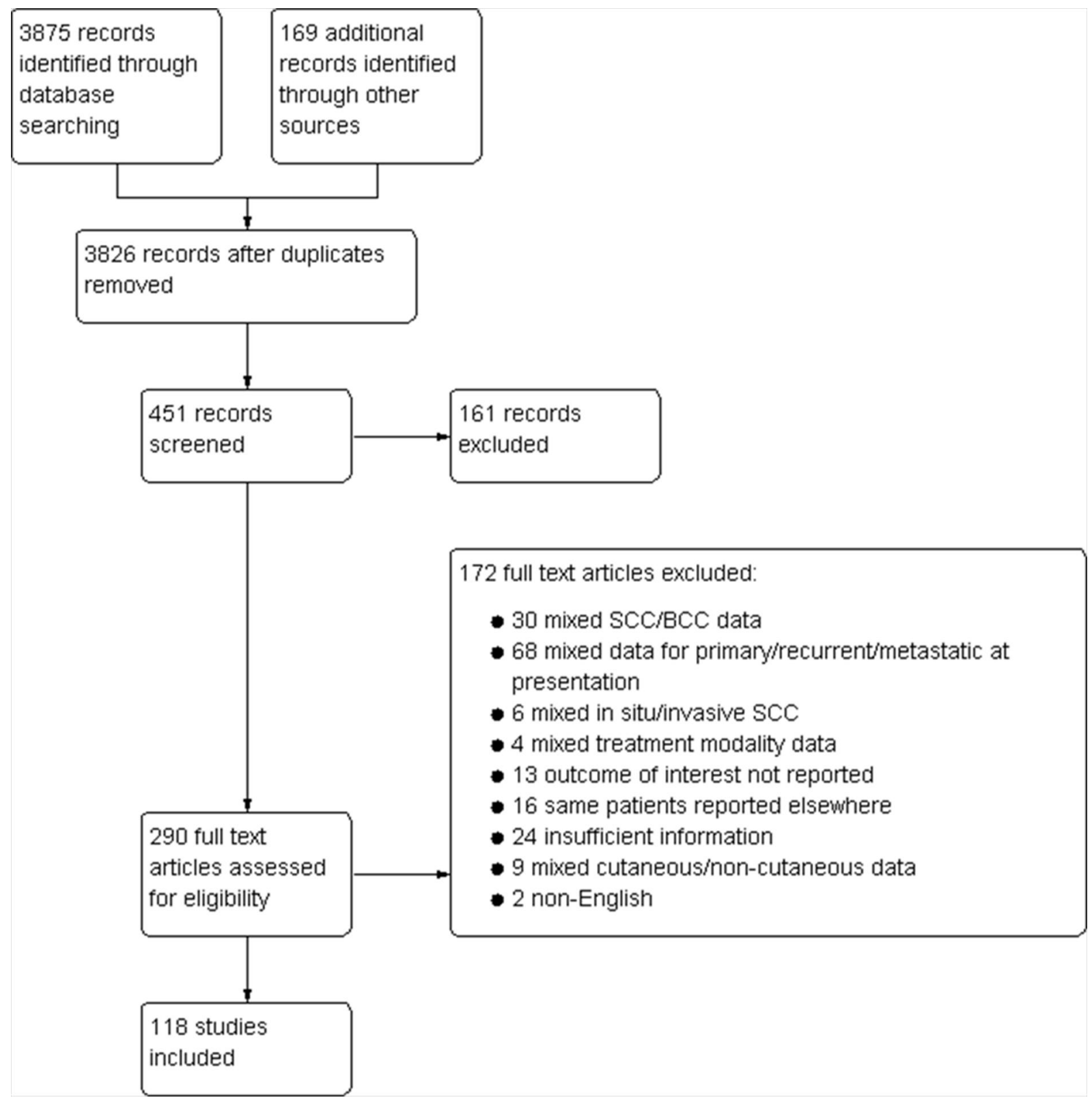

Fig 1 PRISMA flowchart of studies. BCC=basal cell carcinoma

Incomplete outcome data (attition bias)

Gelection

Retraspective design

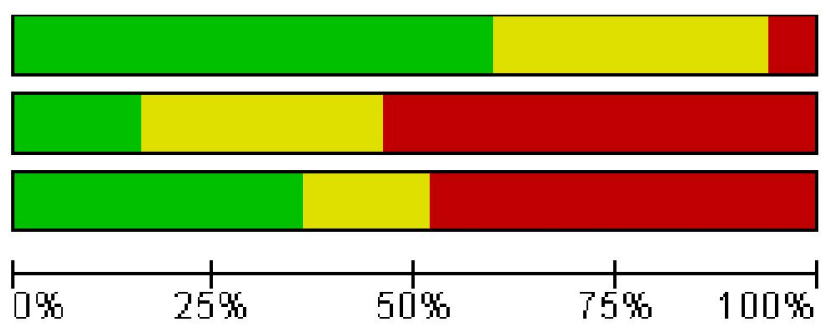

Low risk of bias

Unclear risk of bias $\square$ High risk of bias

Fig 2 Risk of bias assessment of included studies. Percentage indicates proportion of studies 


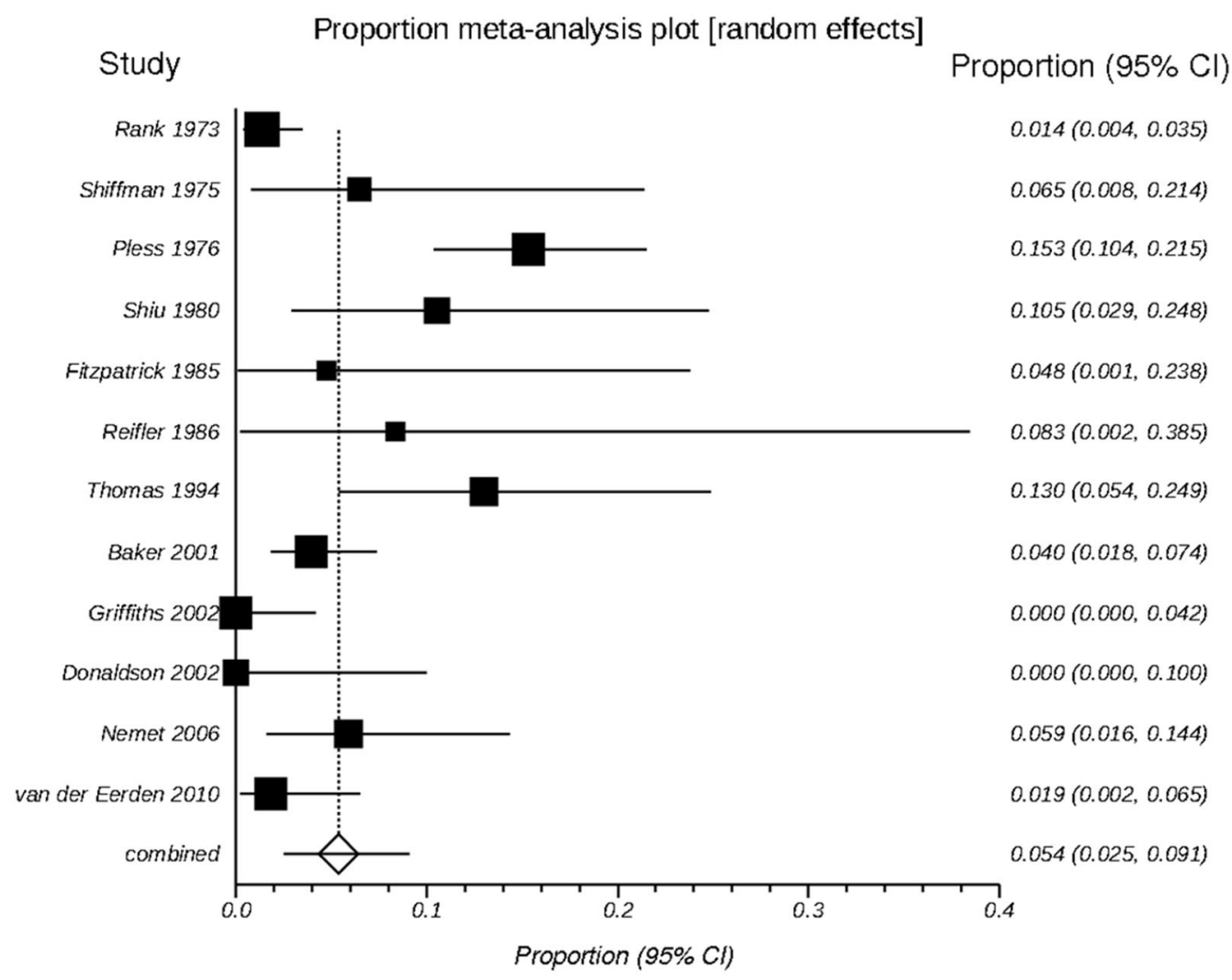

Fig 3 Local recurrence of SCCs after surgical excision 


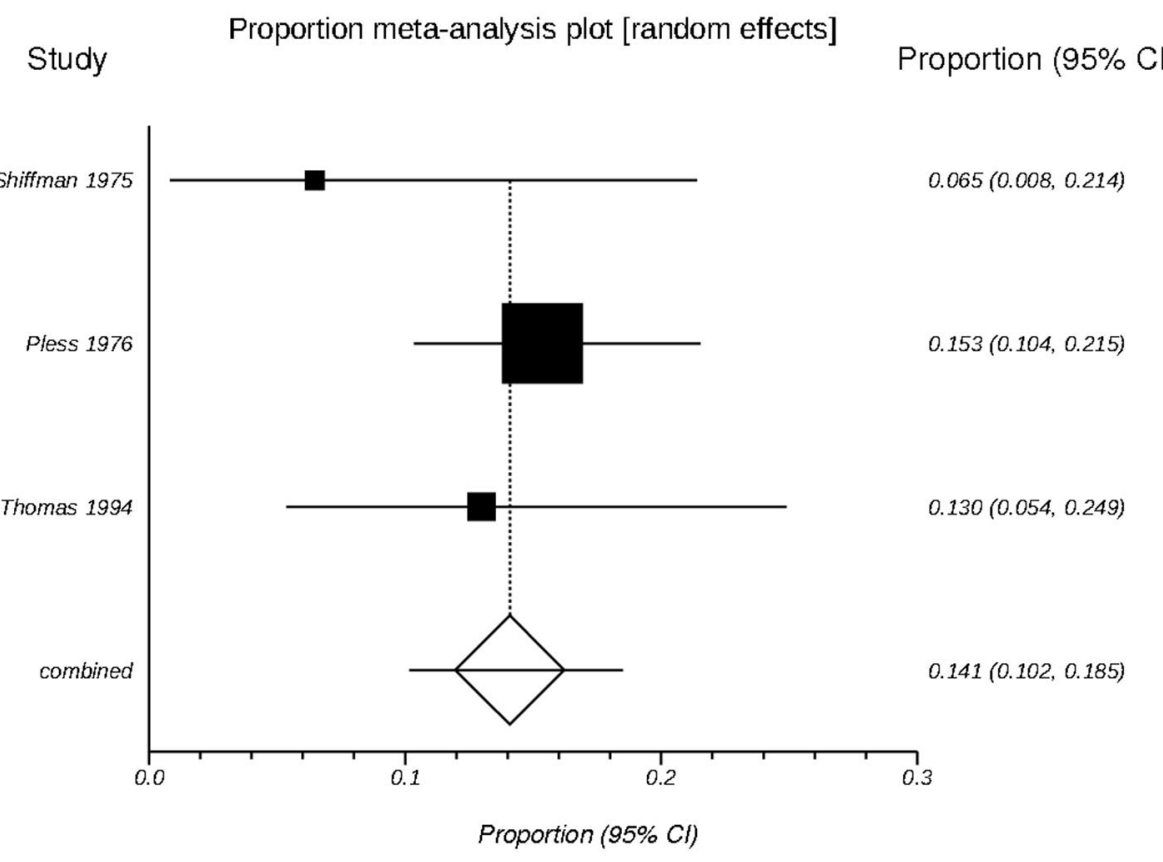

Fig 4 Local recurrence of SCCs in ear locations after surgical excision 


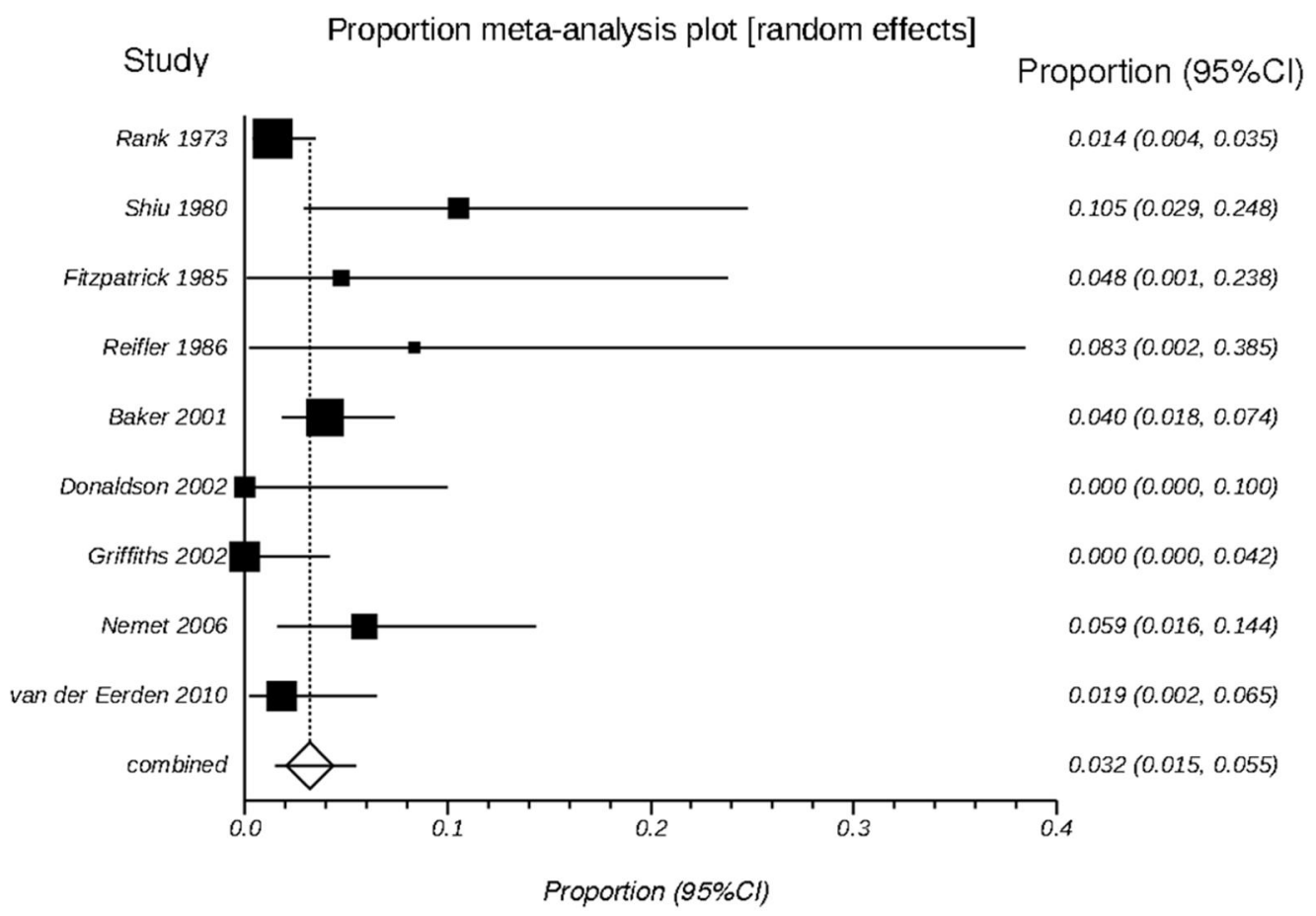

Fig 5 Local recurrence of SCCs in non-ear locations after surgical excision 
Stıdv

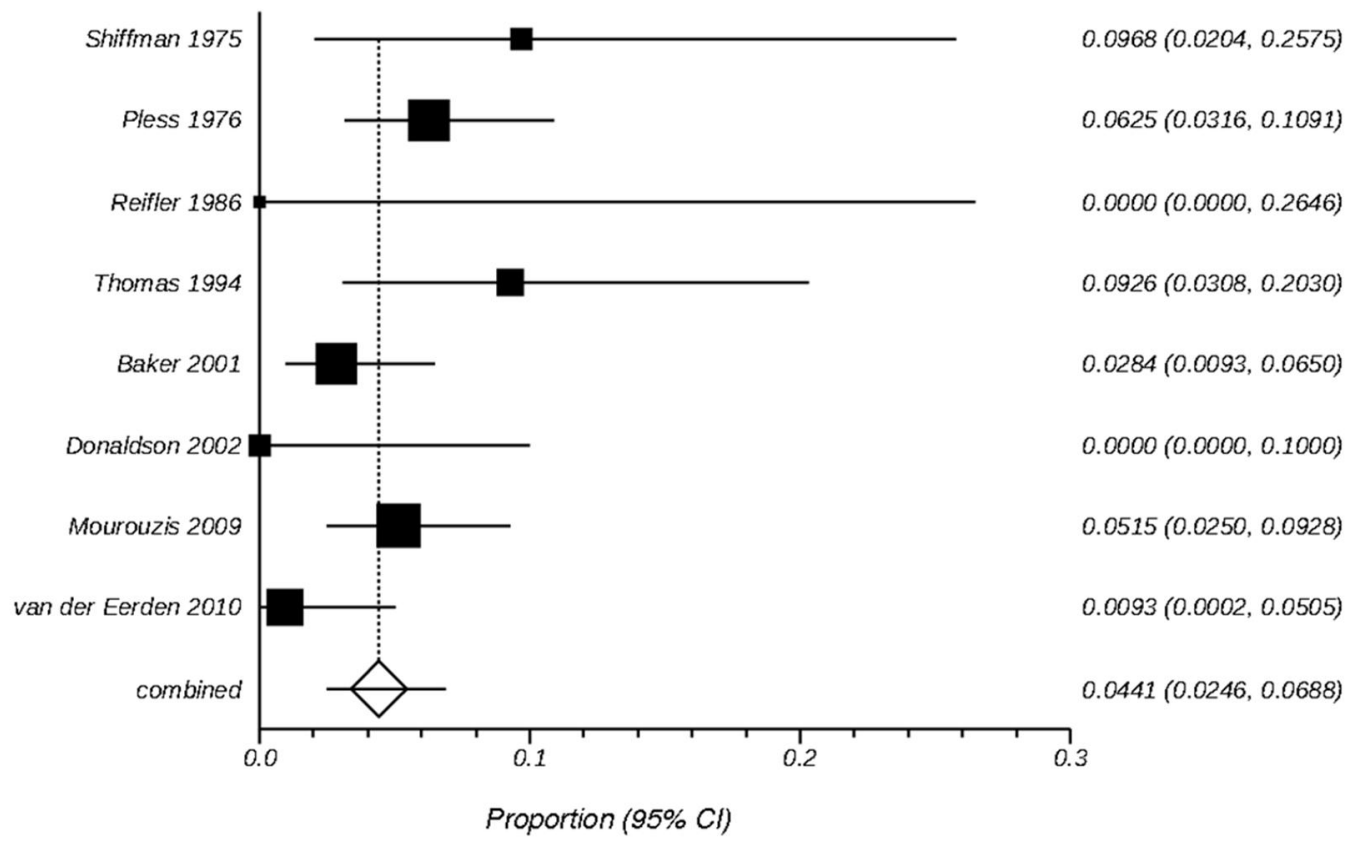

Fig 6 Regional recurrence of SCCs after surgical excision 


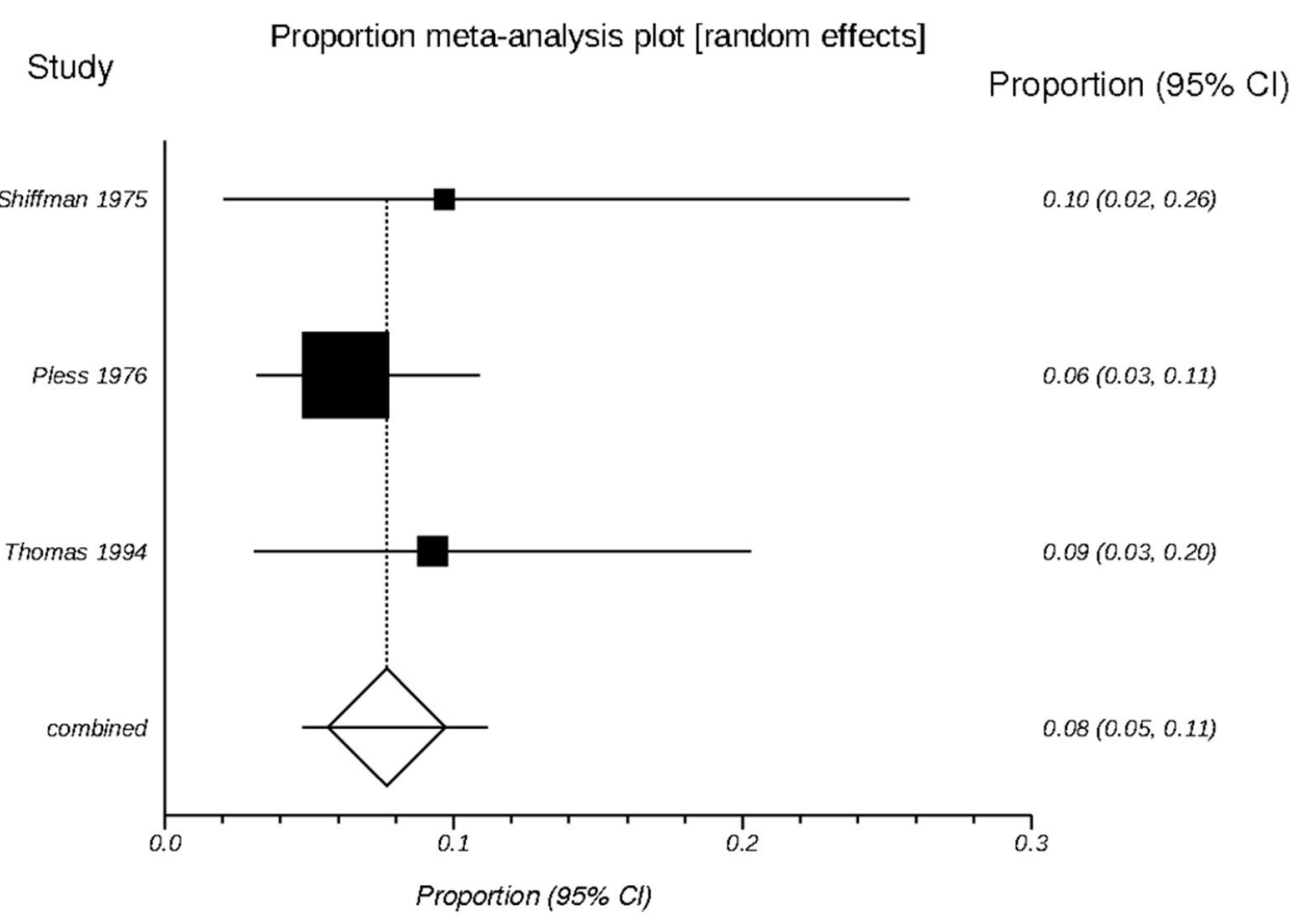

Fig 7 Regional recurrence of SCCs in ear locations after surgical excision 


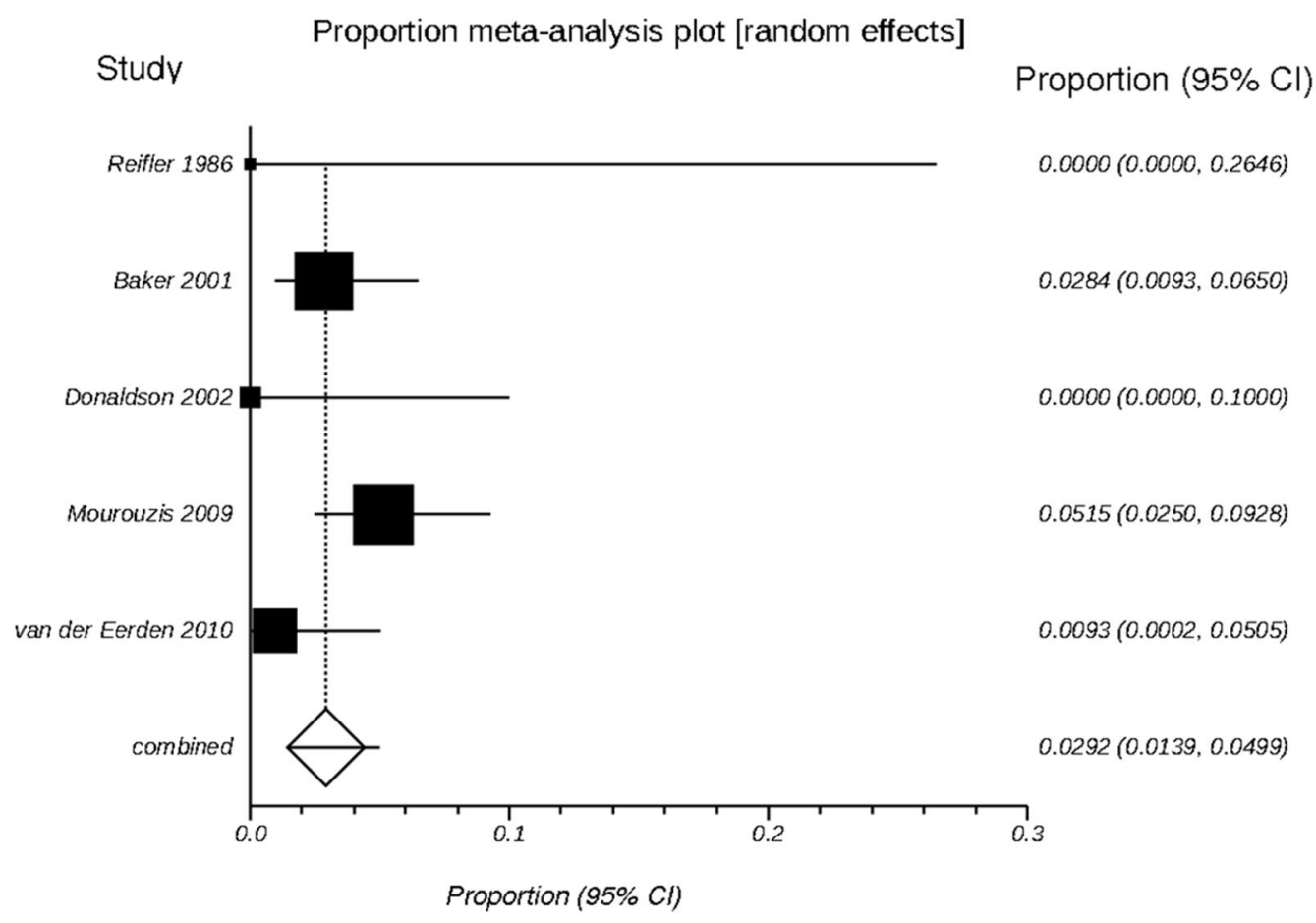

Fig 8 Regional recurrence of SCCs in non-ear locations after surgical excision 


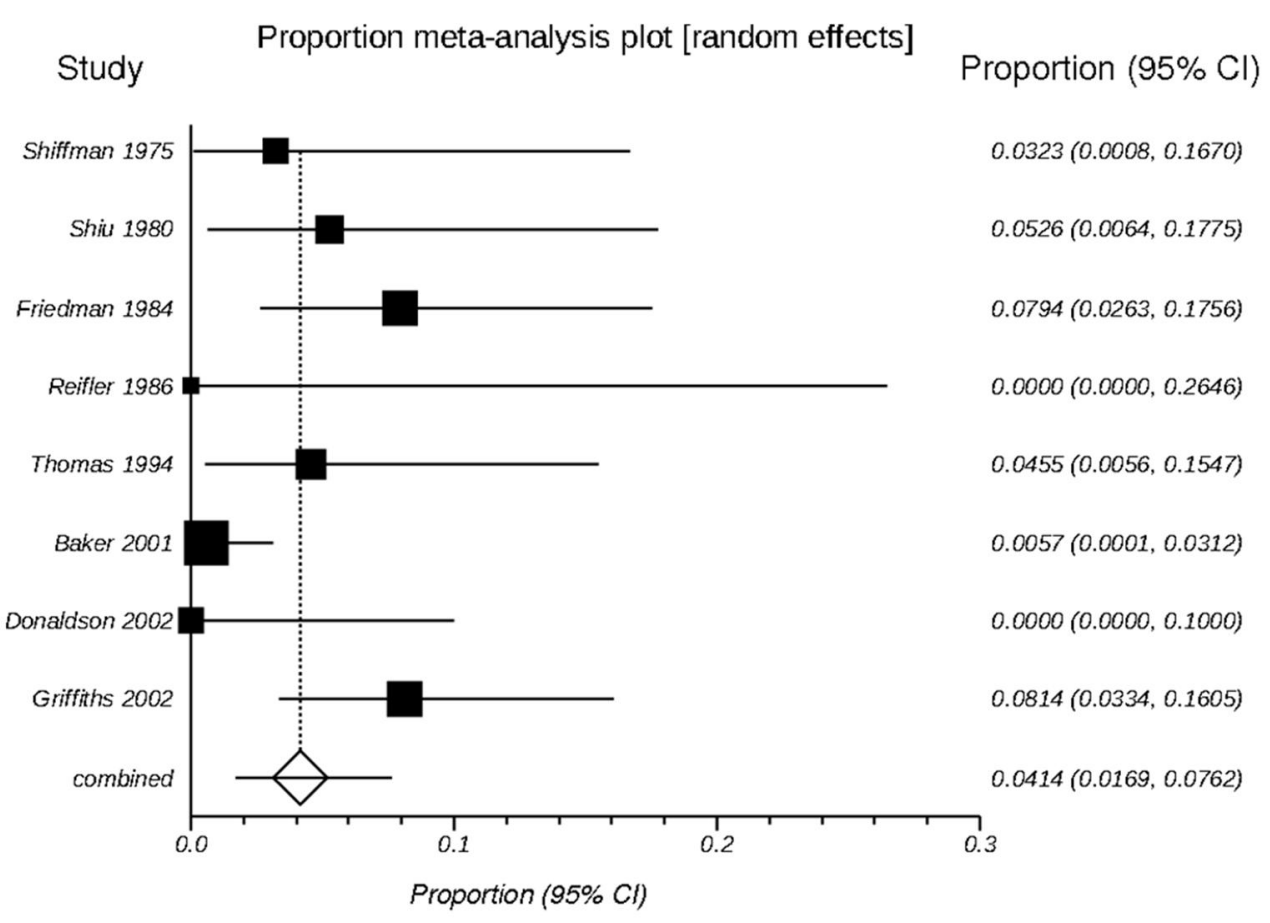

Fig 9 Deaths attributable to disease after surgical excision 


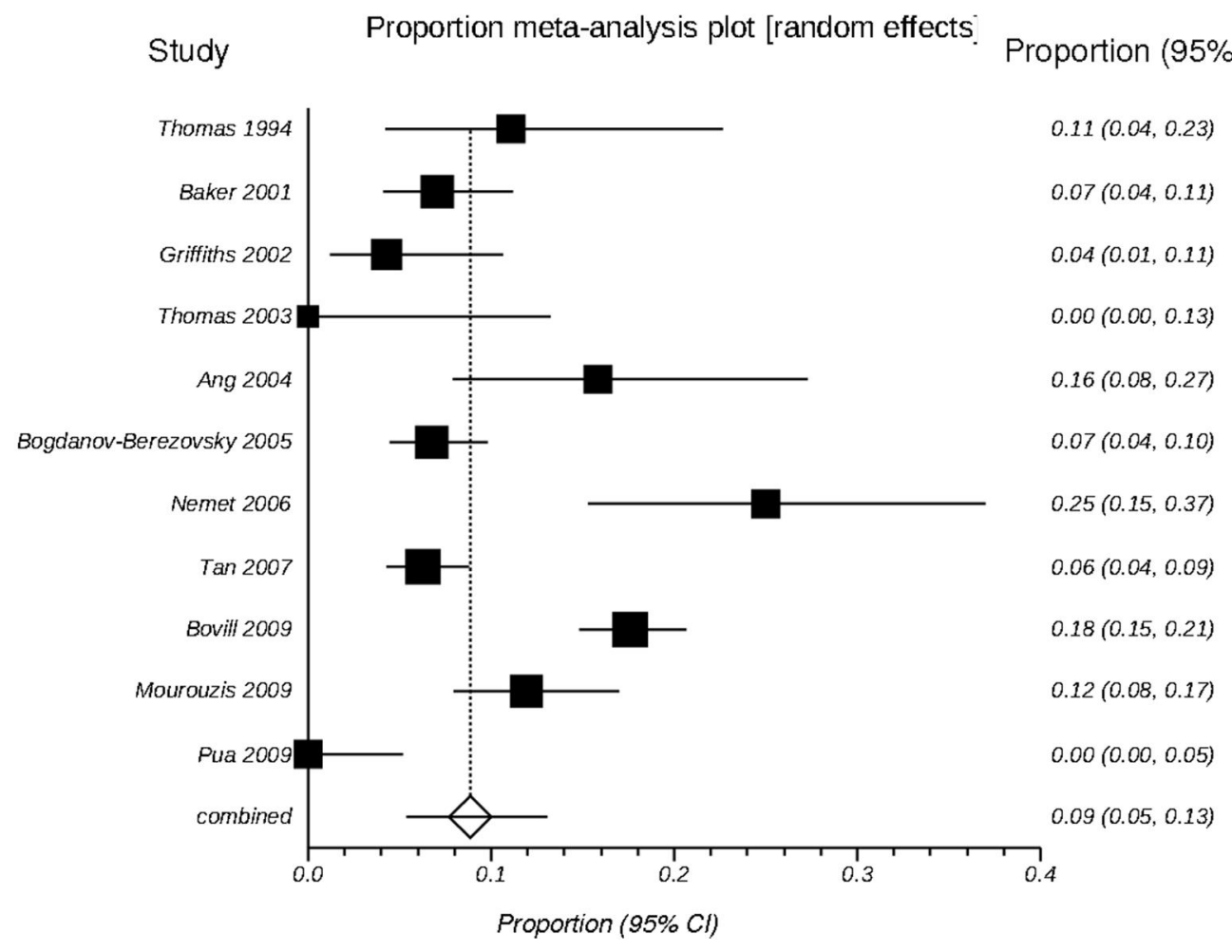

Fig 10 Incomplete excision of SCCs after surgical excision 


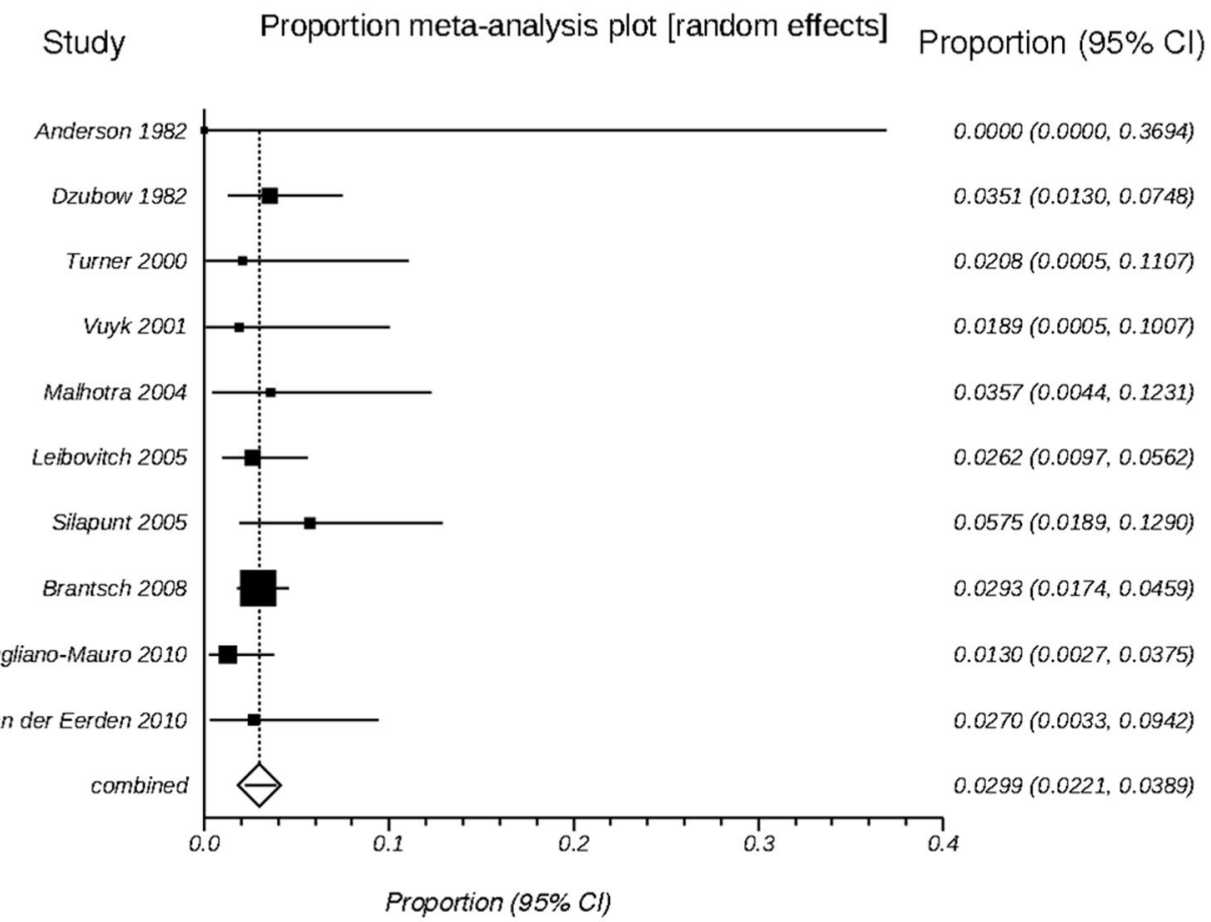

Fig 11 Local recurrence of SCCs after Mohs micrographic surgery 


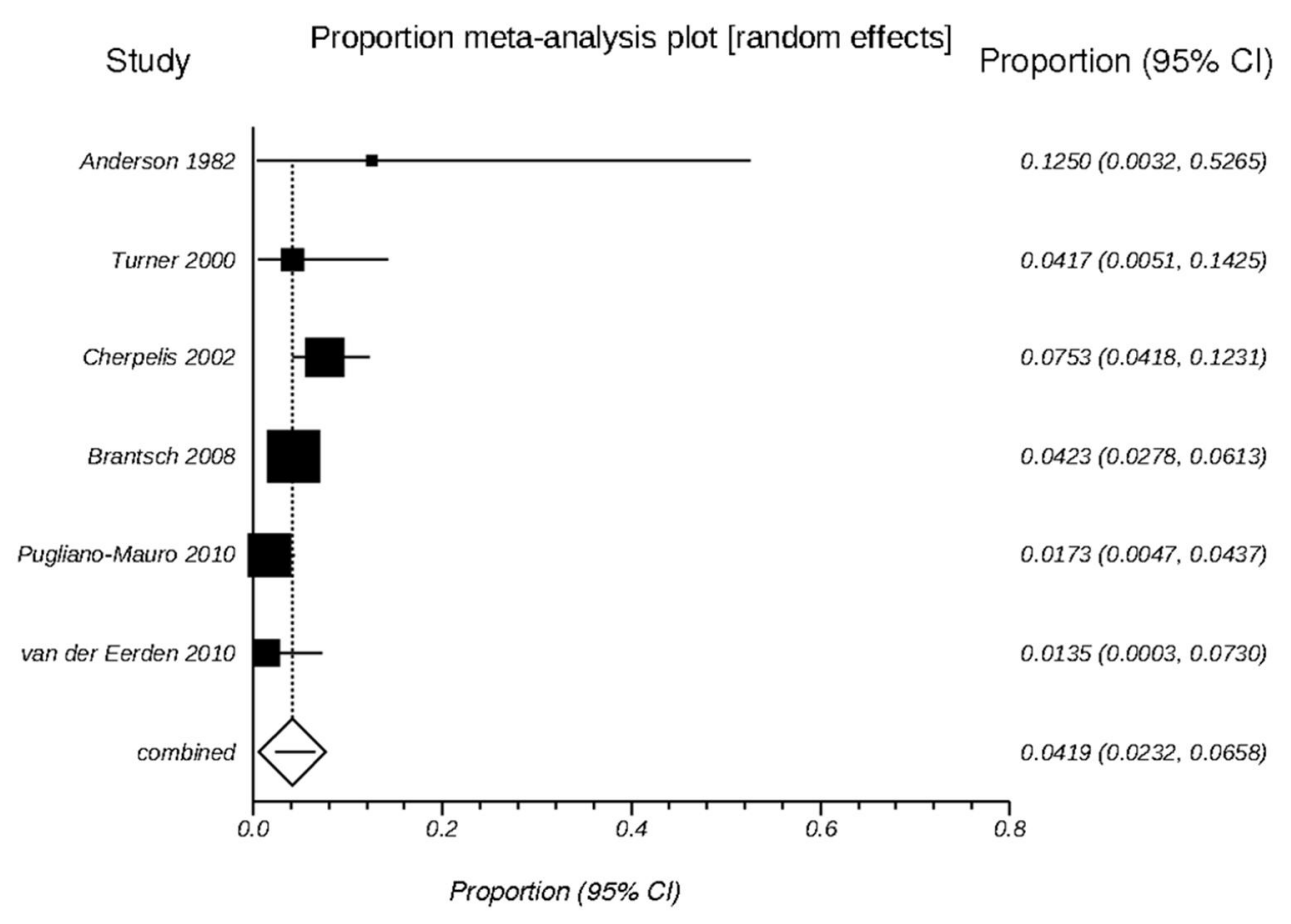

Fig 12 Regional recurrence of SCCs after Mohs micrographic surgery 
Proportion meta-analysis plot [random effects]

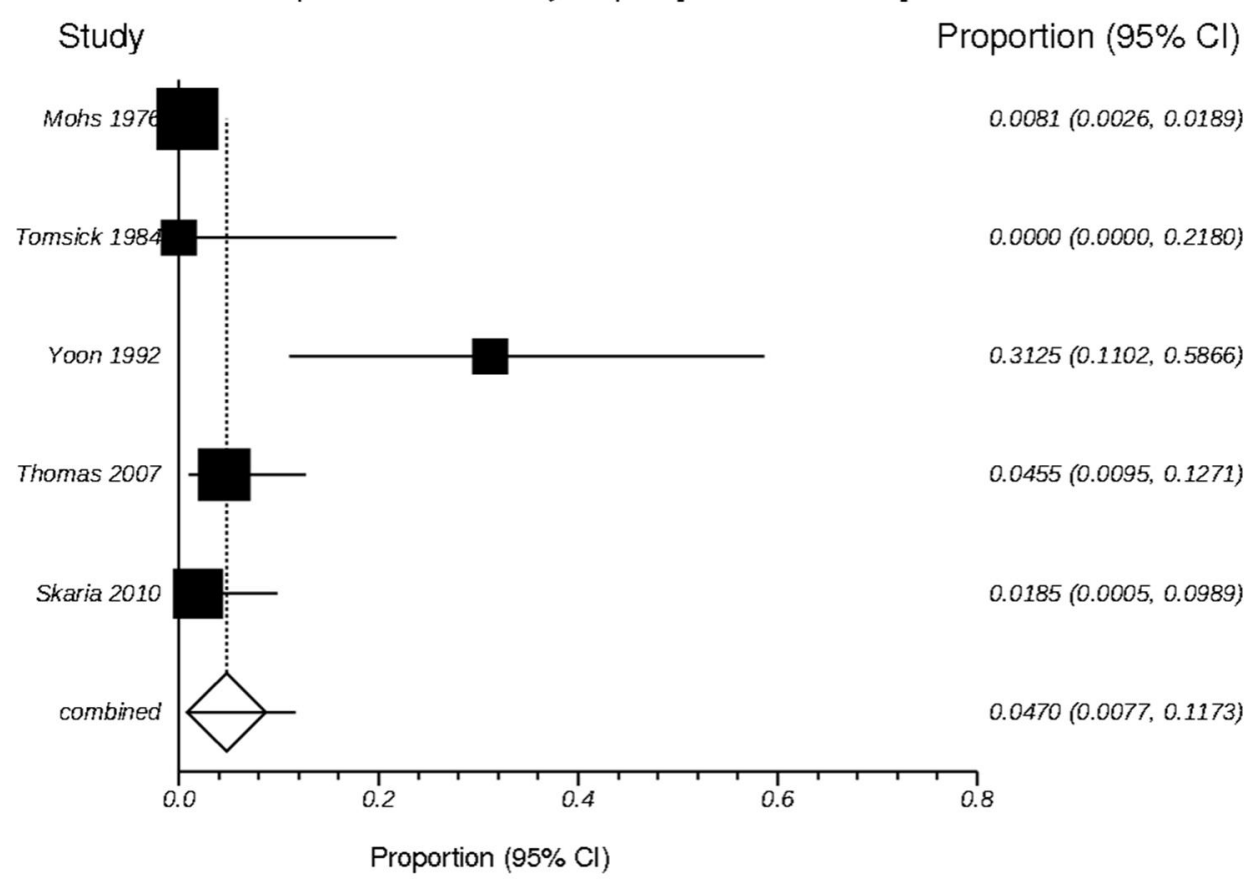

Fig13 Unspecified recurrence of SCCs after Mohs micrographic surgery 


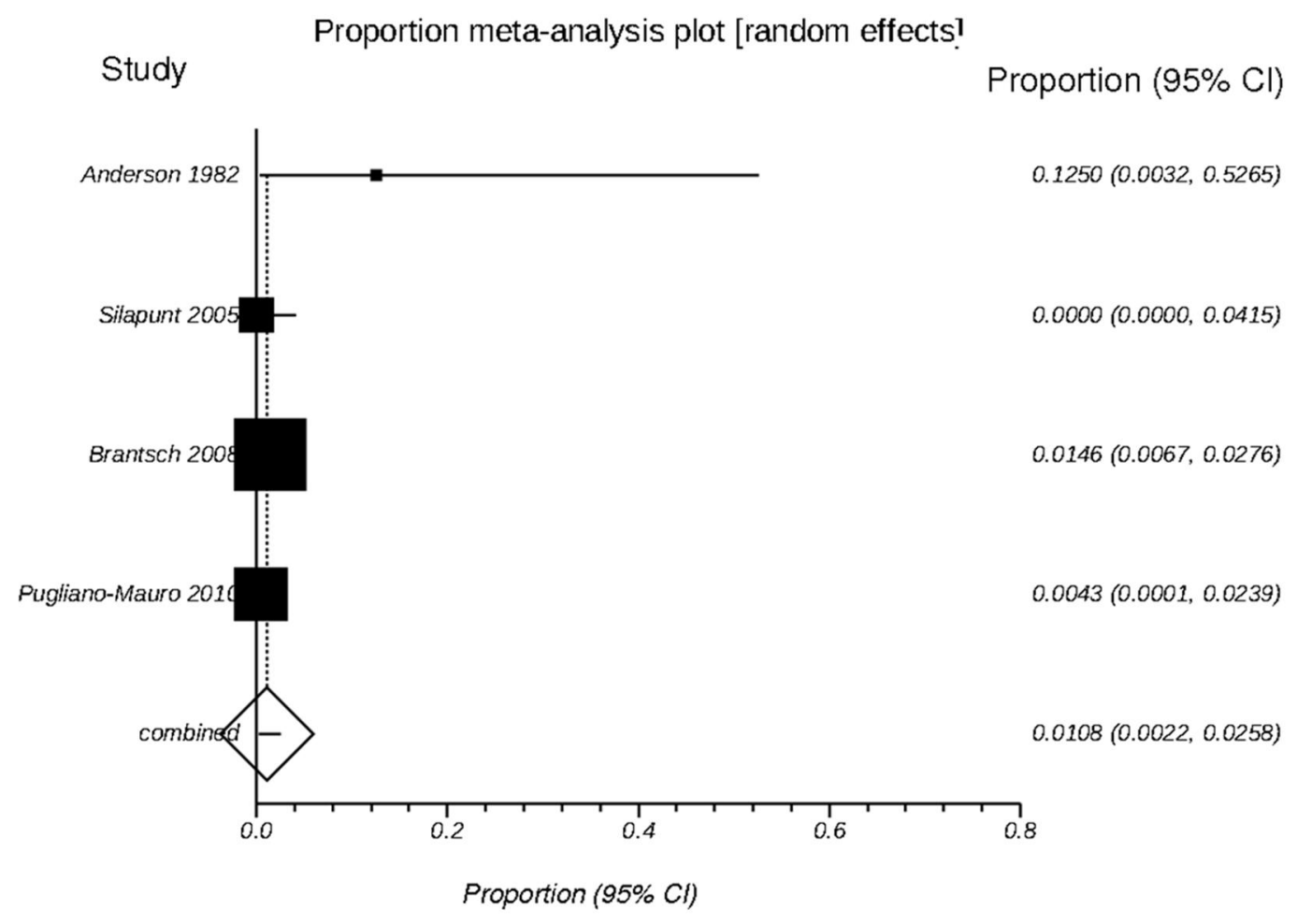

Fig 14 Deaths attributable to disease after Mohs micrographic surgery 


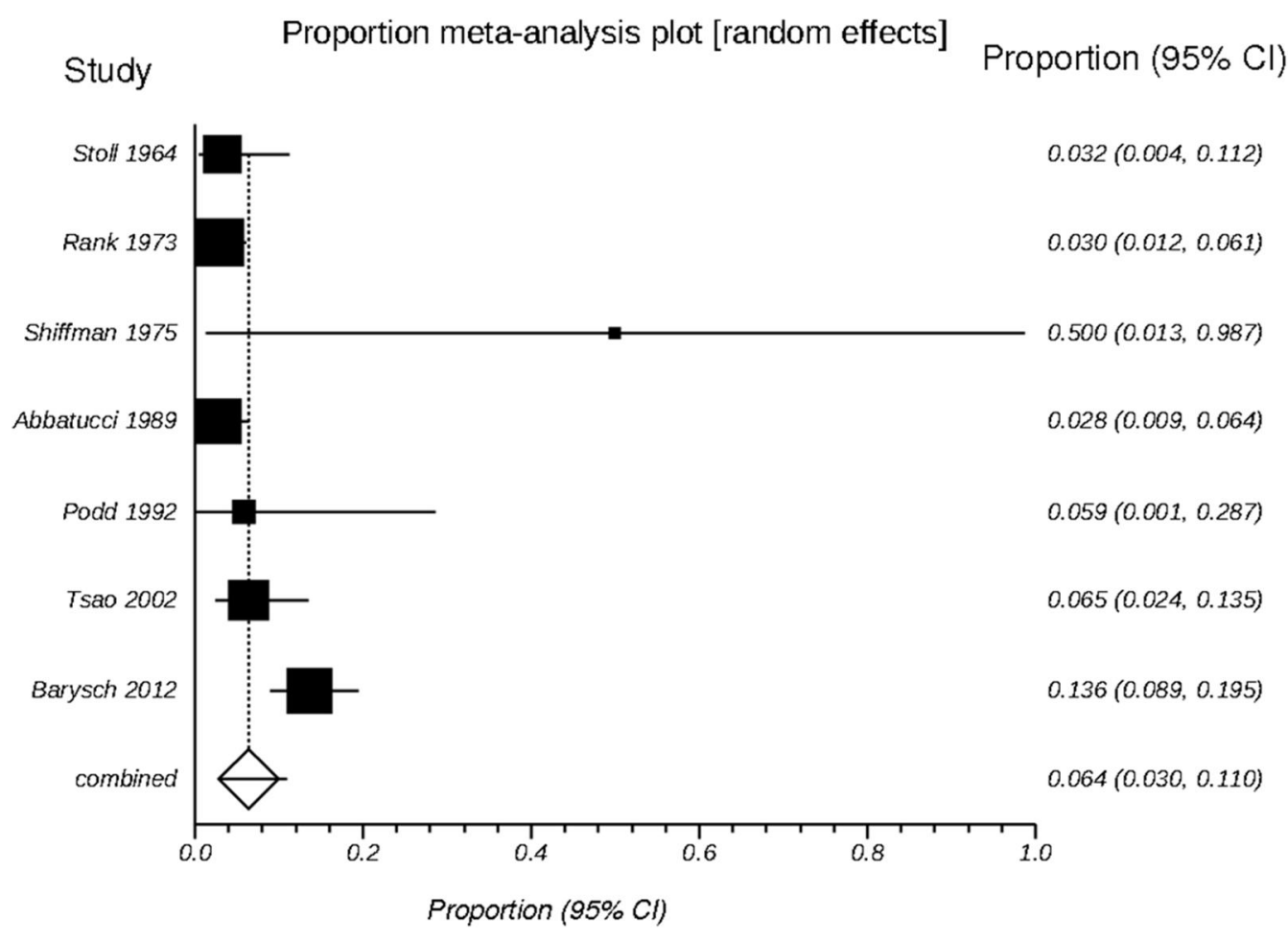

Fig 15 Local recurrence of SCCs after external radiotherapy 
Proportion meta-analysis plot [random effects]

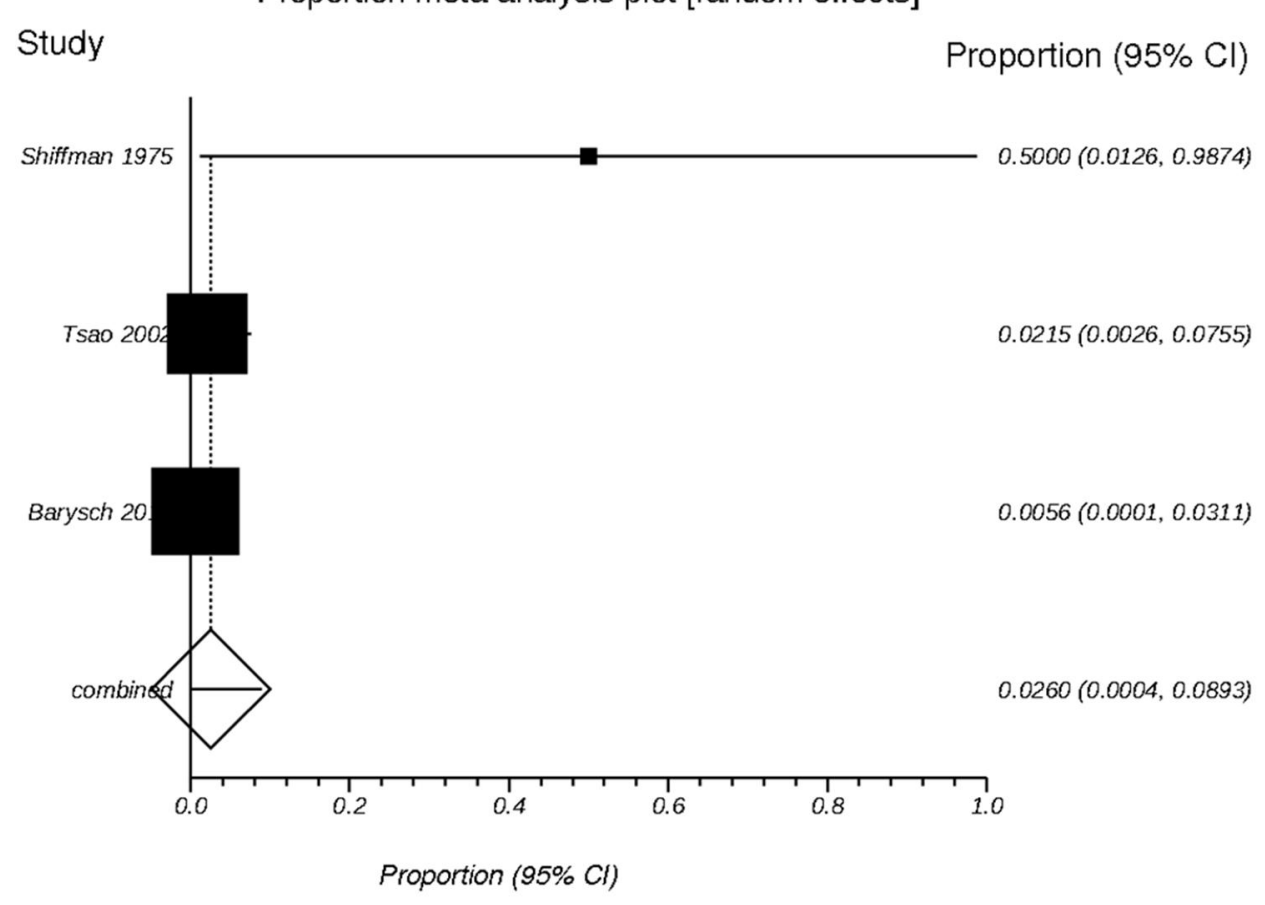

Fig 16 Regional recurrence of SCCs after external radiotherapy 


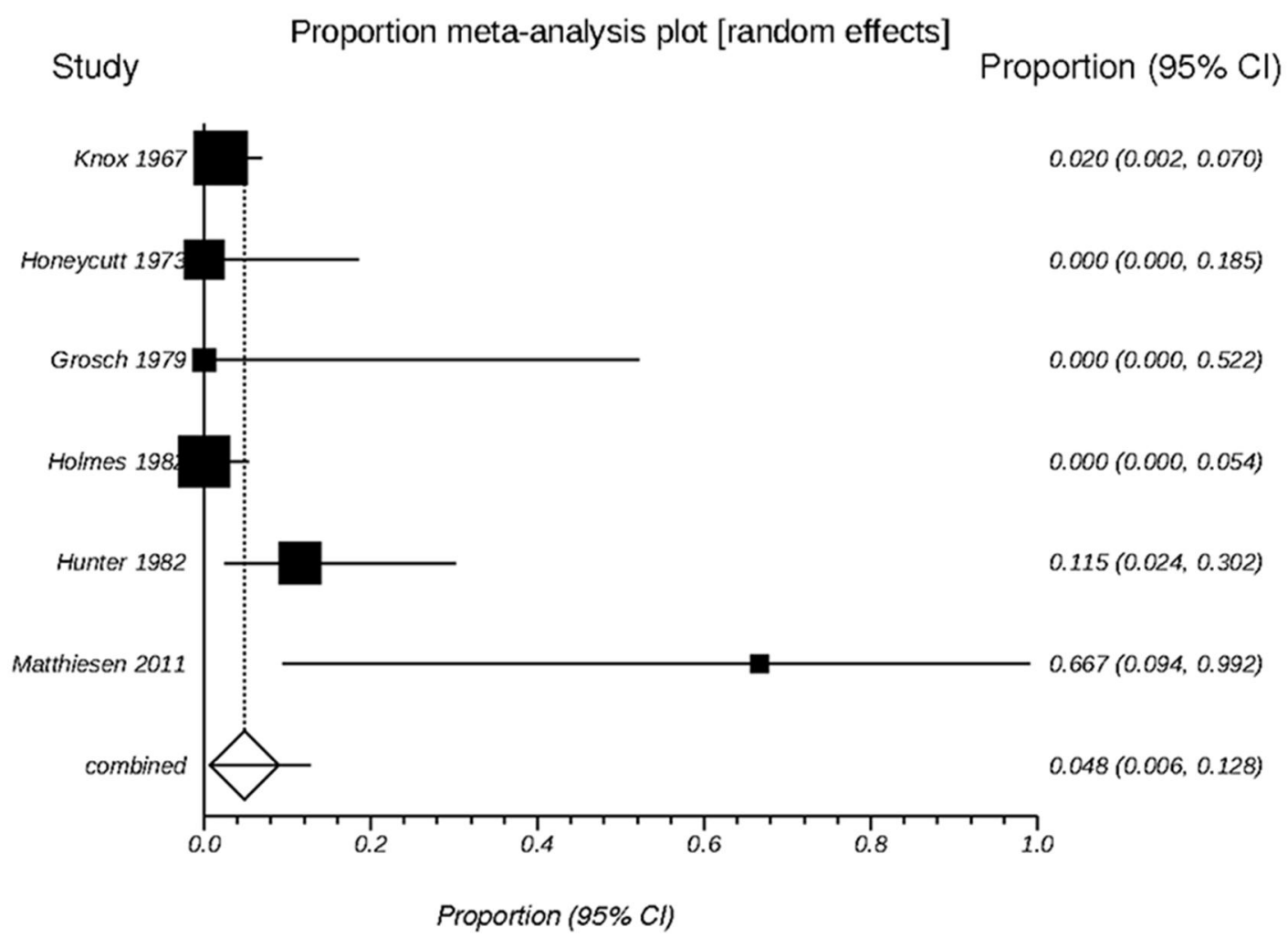

Fig 17 Unspecified recurrence of SCCs after external radiotherapy 
Proportion meta-analysis plot [random effects]

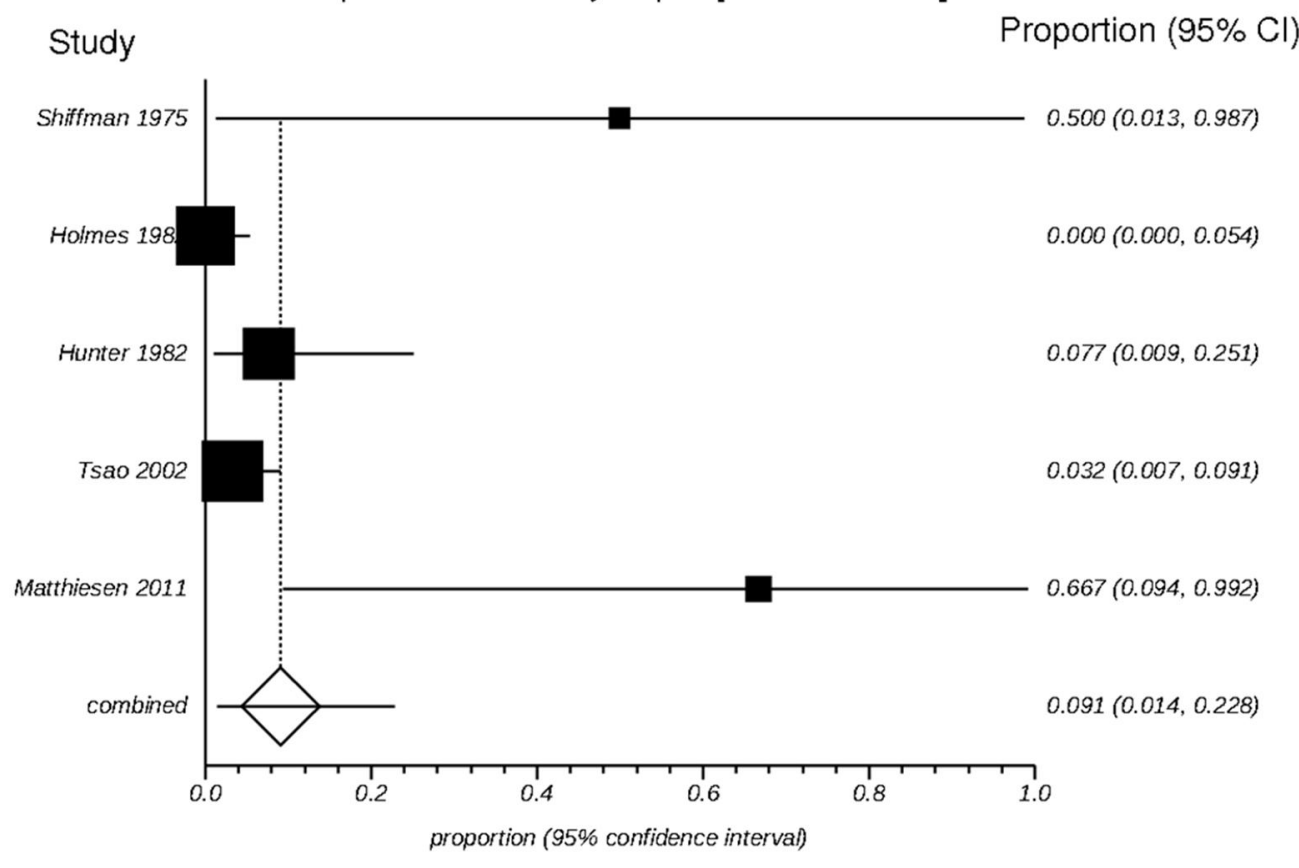

Proportion (95\% Cl)

Fig 18 Deaths attributed to disease after external radiotherapy 


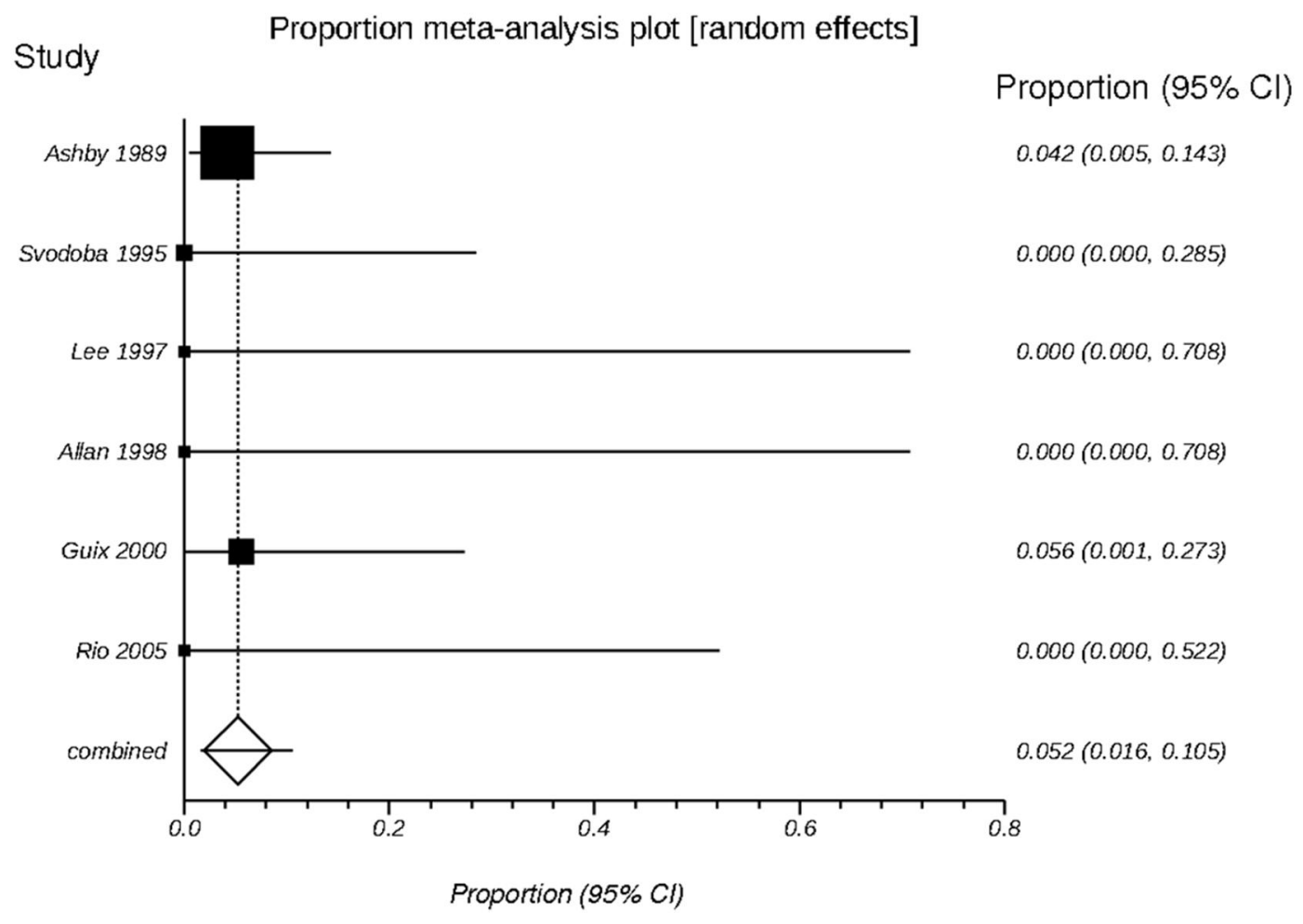

Fig 19 Local recurrence of SCCs after brachytherapy 
Study Proportion meta-analysis plot [random effects]

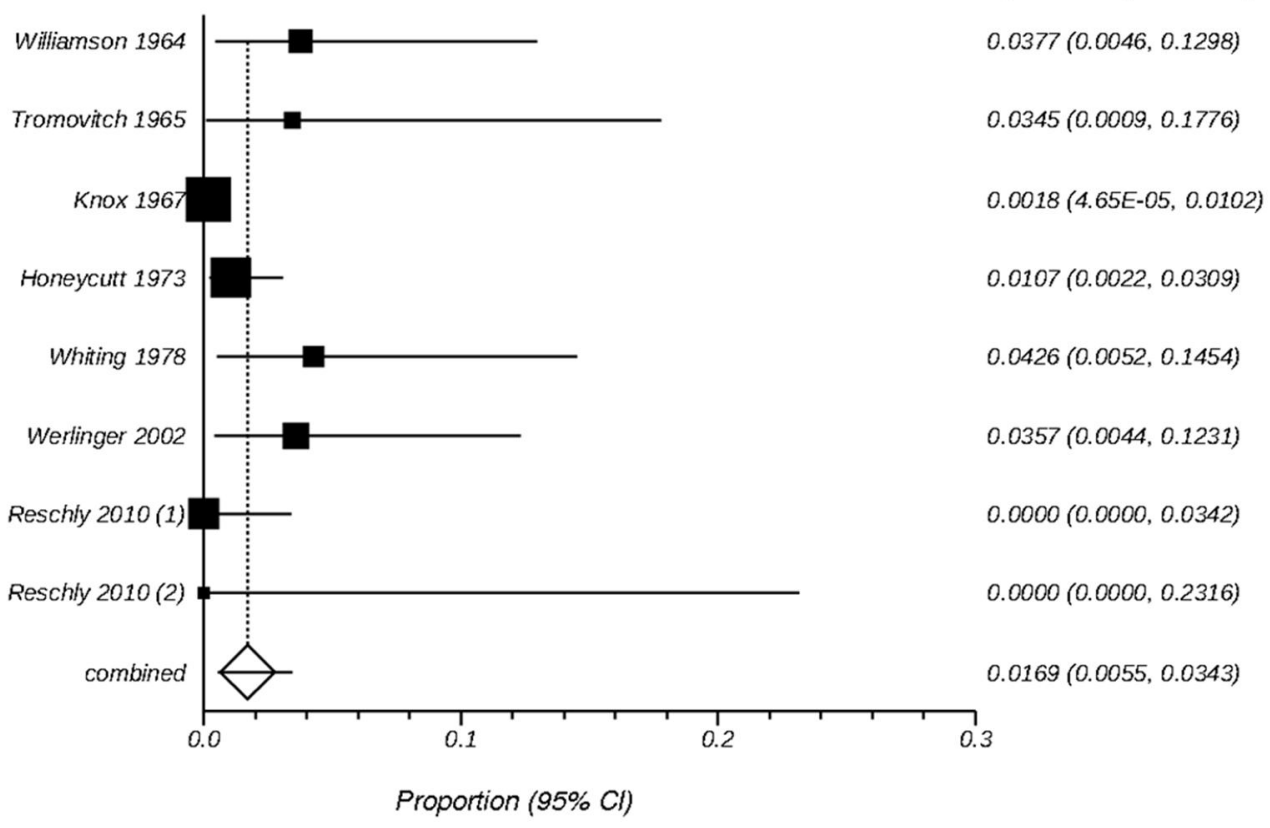

Proportion $(95 \% \mathrm{Cl})$

$0.0377(0.0046,0.1298)$

$0.0345(0.0009,0.1776)$

$0.0018(4.65 E-05,0.0102)$

$0.0107(0.0022,0.0309)$

$0.0426(0.0052,0.1454)$

$0.0000(0.0000,0.0342)$

$0.0000(0.0000,0.2316)$

$0.0169(0.0055,0.0343)$

Fig 20 Unspecified recurrence of SCCs after curettage and electrodesiccation 


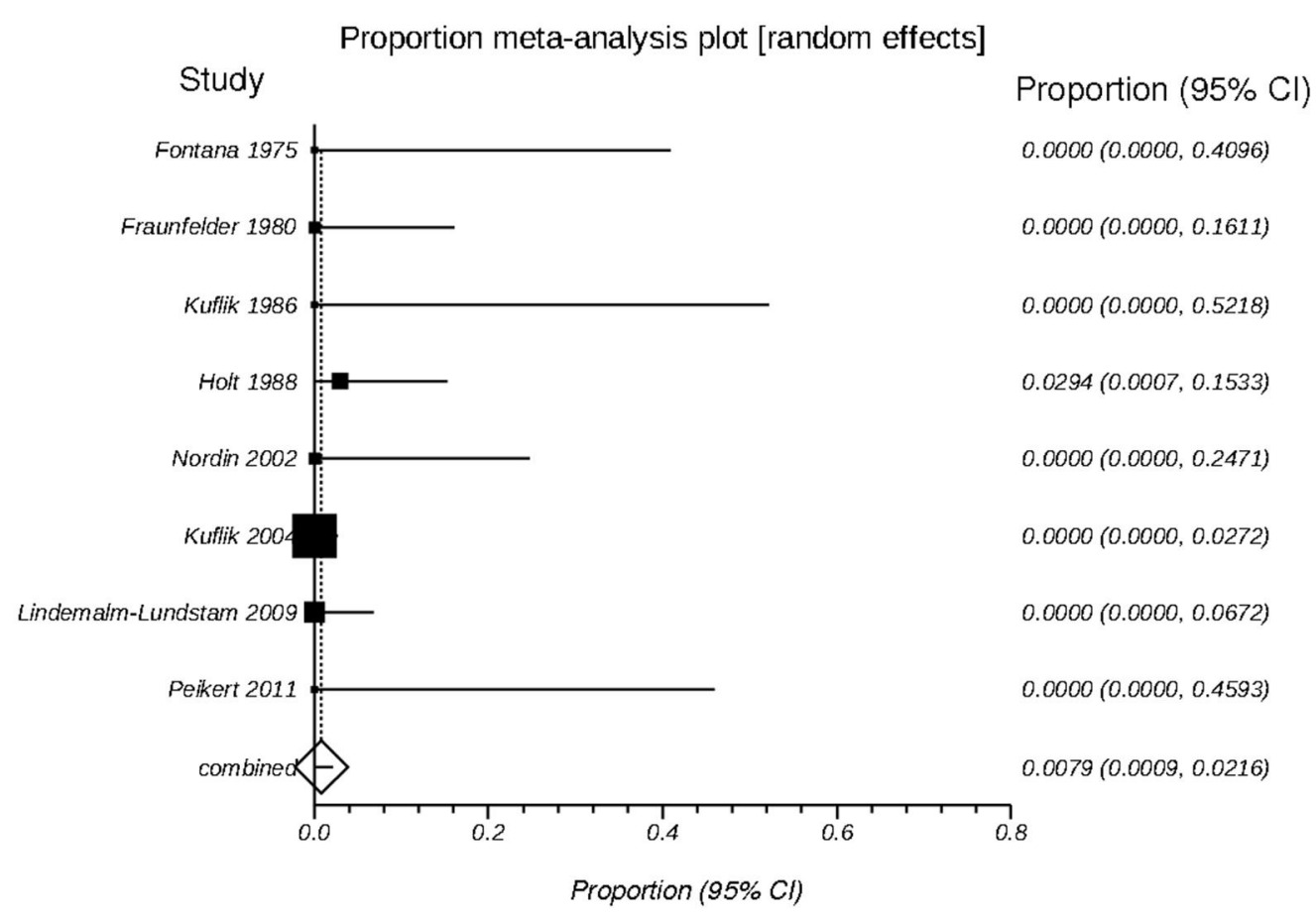

Fig 21 Unspecified recurrence of SCCs after cryotherapy 


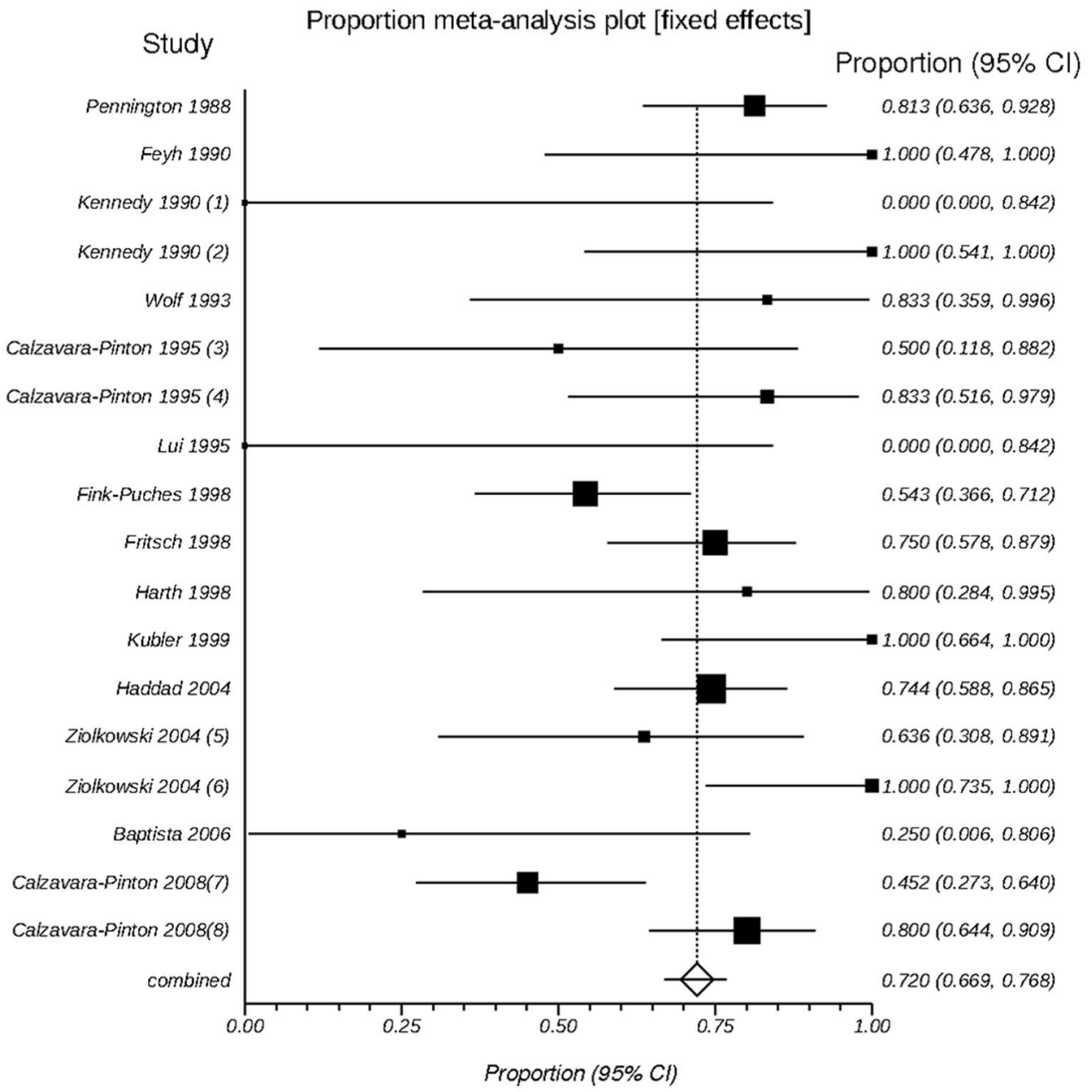

Fig 22 Apparent complete response of SCCs after photodynamic therapy. (1) "elevated" SCCs; (2) "early invasive" SCCs; (3) "nodular" SCCs; (4) "superficial" SCCs; (5) no glycolic acid added to photodynamic therapy; (6) photodynamic therapy plus glycolic acid; (7) "invasive" SCCs; (8) "microinvasive" SCCs 


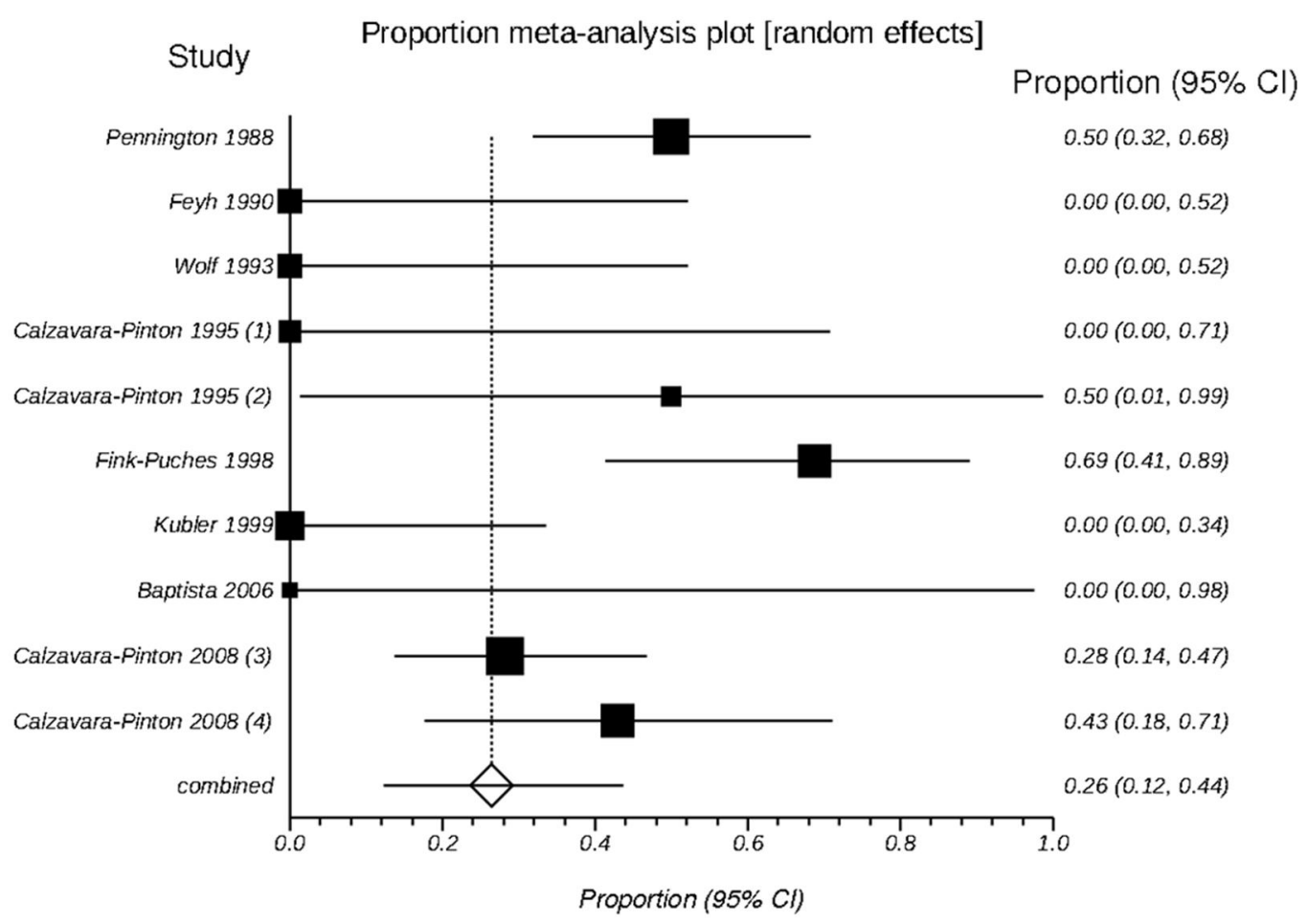

Fig 23 Recurrence after apparent complete response of SCCs following photodynamic therapy. (1) "superficial" SCCs; (2) "nodular" SCCs; (3) "microinvasive" SCCs; (4) "invasive" SCCs 